In cooperation with the WEST VIRGINIA DEPARTMENT OF ENVIRONMENTAL PROTECTION, DIVISION OF MINING AND RECLAMATION

Calibration Parameters Used to Simulate Streamflow from Application of the Hydrologic Simulation Program-FORTRAN Model (HSPF) to Mountainous Basins Containing Coal Mines in West Virginia



Scientific Investigations Report 2005-5099 
Front cover: View of Panther Creek, McDowell County, West Virginia. The gaging station on Panther Creek near Panther (USGS station 03213500) was one of those selected for modeling discussed in this report. Photograph by Terence Messinger, USGS, 2005. 


\title{
Calibration Parameters Used to Simulate Streamflow from Application of the Hydrologic Simulation Program- FORTRAN Model (HSPF) to Mountainous Basins Containing Coal Mines in West Virginia
}

\author{
By John T. Atkins Jr., Jeffrey B. Wiley, and Katherine S. Paybins
}

\section{Abstract}

This report presents the Hydrologic Simulation ProgramFORTRAN Model (HSPF) parameters for eight basins in the coal-mining region of West Virginia. The magnitude and characteristics of model parameters from this study will assist users of HSPF in simulating streamflow at other basins in the coal-mining region of West Virginia.

The parameter for nominal capacity of the upper-zone storage, UZSN, increased from south to north. The increase in UZSN with the increase in basin latitude could be due to decreasing slopes, decreasing rockiness of the soils, and increasing soil depths from south to north.

A special action was given to the parameter for fraction of ground-water inflow that flows to inactive ground water, DEEPFR. The basis for this special action was related to the seasonal movement of the water table and transpiration from trees.

The models were most sensitive to DEEPFR and the parameter for interception storage capacity, CEPSC. The models were also fairly sensitive to the parameter for an index representing the infiltration capacity of the soil, INFILT; the parameter for indicating the behavior of the ground-water recession flow, KVARY; the parameter for the basic groundwater recession rate, AGWRC; the parameter for nominal capacity of the upper zone storage, UZSN; the parameter for the interflow inflow, INTFW; the parameter for the interflow recession constant, IRC; and the parameter for lower zone evapotranspiration, LZETP.

\section{Introduction}

Coal production in West Virginia accounted for about 15 percent of the total coal production in the United States in 2001, and West Virginia ranked as the second largest coal-producing State, with 175 million tons. Underground coal mining began in the early 1700s, and production increased until the 1950s. Underground coal-mining production decreased through the 1990s and in 2002 accounted for approximately 63 percent of the total coal production in the State. Underground longwall-mining production has increased, although the total underground production has decreased since the 1990s. Surface coal mining began around 1916, but appreciable production did not occur until the 1940s. Surface-mining production has increased through the 1990s and in 2001 accounted for approximately 37 percent of the total coal production in the State. The surface-mining technique called mountaintop removal (steep-slope, mountaintop-mining, and multiple-seam mining) largely accounts for the production increase in the 1990s (Office of Surface Mining Reclamation and Enforcement, 2003).

West Virginia passed the first law in the United States setting reclamation standards for coal-mining operations in 1939, but mining operations prior to the passage of the Surface Mining Control and Reclamation Act of 1977 (SMCRA) resulted in many unreclaimed or underreclaimed areas in West Virginia. The Office of Surface Mining Reclamation and Enforcement (OSM) was created within the U.S. Department of Interior upon passage of SMCRA. OSM provides Federal funding for State regulatory programs, including West Virginia's, that meet the standards of SMCRA (Roger T. Hall, West Virginia Department of Environmental Protection, Division of Mining and Reclamation, written commun., 1998; Office of Surface Mining Reclamation and Enforcement, 2003).

The West Virginia Department of Environmental Protection, Division of Mining and Reclamation (WVDEP/DMR) presently (2005) is assessing the cumulative hydrologic impacts of coal mining in West Virginia. Approximately 240 basins with drainage areas between approximately 30 and 80 $\mathrm{mi}^{2}$ in the coal-mining region of West Virginia have been identified for assessment. Effects of coal mining on streamflow will be quantified at the basin outflow locations by use of the Hydrological Simulation Program-FORTRAN (HSPF) model (U.S. Environmental Protection Agency, 1996). The effects on water quality from coal mining also will be assessed, but the HSPF model may not be applied for these effects. The magnitude of and relation among calibration parameters, particu- 
larly relating to the effects of mining, are needed to facilitate application of the HSPF model.

The U.S. Geological Survey (USGS), in cooperation with the West Virginia Department of Environmental Protection, Division of Mining and Reclamation, began a study in 2003 to apply the HSPF model to selected basins within and adjacent to the more mountainous coal-mining region of West Virginia to determine the magnitude and characteristics of streamflowcalibration parameters. The model-simulated basins are spatially distributed across the coal-mining region, and calibration parameters are compared among land-use categories. Parameter values determined from this study will assist in determining HSPF model parameters for approximately 240 basins in West Virginia selected by WVDEP/DMR for a Cumulative Hydrologic Impact Assessment (CHIA).

\section{Purpose and Scope}

This report documents eight individual HSPF watershed model applications to determine values of calibration parameters for simulating streamflow in the coal-mining region of West Virginia. The values of parameters used for simulations were not forced to be similar among the basins modeled although initial values were set equal to those of a prior HSPF simulation in the Eastern Panhandle of West Virginia.

This report contains (1) a basic description of data sources, (2) a complete set of model parameters, (3) a complete set of calibrations hydrographs, (4) and statistical comparisons. Discussions include the methodologies used or explored, the calibration process, the validation results, and what can be inferred about the hydrologic systems.

\section{Background}

Underground coal mining can affect the hydrologic system. Increased void volume from underground mining and fractures produced by mine-roof collapses can increase the movement of water from upper water-bearing rock units to lower mined coal seams. Decreased evapotranspiration can result from draining available moisture near the land surface. Increased streamflow in one basin and decreased streamflow in another basin can result where underground mining crosses drainage divides; for example, where water is pumped out of the mines to a different basin during active mining or where water seeps out of mines into different drainages after mining ceases. Increased base flows can result from the drainage of water accumulated in abandoned and flooded underground mines. (Hobba, 1981; Puente and Atkins, 1989; Ward and Wilmoth, 1968)

Surface coal mining also can affect the hydrologic system. Increased ground-water recharge and decreased peak discharges can result from interception and retention of storm runoff by strip benches. Increased streamflow in one basin and decreased streamflow in another basin can result from diversion of flow by strip benches. Aside from disturbance of land, tree removal that accompanies surface mining can increase runoff by reducing interception and evapotranstiration. Increased base flows and increased or decreased peak discharges can result from valley fills. (Borchers and others, 1991; Messinger , 2002; Messinger and Paybins, 2003; Puente and Atkins, 1989; Wiley and Brogan, 2003; Wiley and others, 2001)

Other factors can affect the hydrologic system. It is difficult to find basins with available steamflow record that are not disturbed by factors other than mining. These include natural factors such as landslides, forest fires, wind damage, and floods, and also human activities such as road construction, site development, logging, urbanization, agriculture, and industrial use. Careful selection of basins for simulation can avoid basins dominated by these non-mining factors.

\section{Description of Study Area}

The coal-mining region of West Virginia is in the Appalachian Plateaus Physiographic Province and extends from the northern panhandle through central to southwestern West Virginia. The shaded areas of figure 1, which includes the "240 basins" referred to previously, are within the coal-mining region of West Virginia and are more mountainous than the remainder of the coal-mining region. The shaded areas are those that will be of interest for future CHIAs (T. Galya, Office of Surface Mining Reclamation and Enforcement, oral commun., 2003). Eight streams in or near the shaded areas for which USGS streamflow records were available were selected for simulation (table 1).

Strata of consolidated, mostly noncarbonate sedimentary rocks generally dip to the northwest and strike to the northeast. Streams have eroded the rocks, forming steep hills with deeply incised valleys that follow a dendritic pattern; uplifted plateaus also have formed in areas of resistant layers of shale (Fenneman, 1938; Fenneman and Johnson, 1946; and U.S. Geological Survey, 1970). Most ground water flows in bedding-plane separations beneath the valley floors and in slump fractures along the valley walls (Wyrick and Borchers, 1981). Generally, ground-water movement is greater laterally than vertically, decreases with increasing depth, and is negligible below about $100 \mathrm{ft}$ except in coal seams, where ground-water movement can be substantial at depths greater than $200 \mathrm{ft}$ (Harlow and LeCain, 1993).

The climate is primarily continental, with mild summers and cold winters (U.S. Geological Survey, 1991). Average annual precipitation ranges from about $40 \mathrm{in}$. along the Ohio River to about $60 \mathrm{in}$. in the higher elevations in east-central West Virginia, along the eastern boundary of the coal-mining region (U.S. Department of Commerce, 1960). The 24-hour precipitation intensity falling on the average of once every 2 years ranges from about $2.5 \mathrm{in}$. along the Ohio River in the northern panhandle to about $2.8 \mathrm{in}$. along the eastern boundary of the coal-mining region (U.S. Department of Commerce, 1961). Average annual snowfall ranges from about 20 to 100 
in. from eastern West Virginia to the higher elevations in eastcentral West Virginia along the eastern boundary of the coalmining region (U.S. Department of Commerce, 1968).

\section{Selection of Model-Simulated Basins}

All USGS streamflow-gaging stations near or within the shaded study area in figure 1 were considered for application of the HSPF model. The streamflow stations were ranked by years of streamflow data so that preference could be given to streamflow stations with longer periods of record. The extent of mining within each basin was considered along with the period of streamflow record. Selection preference was given to stations with the availability of both an unmined and mined period of streamflow record. Finally, the stations were selected in a manner to provide an areal distribution across the coal-mining region. One site outside the study area (BRANDYWINE) and the eight selected stations are listed in table 1. The selected stations are at the termini of mountainous basins containing coal mines.

\section{Simulation with the Hydrologic Simulation Program-FORTRAN (HSPF) Model}

The Hydrological Simulation Program - FORTRAN (HSPF) model is a nonproprietary system of simulation modules in standard FORTRAN first released in 1980. HSPF

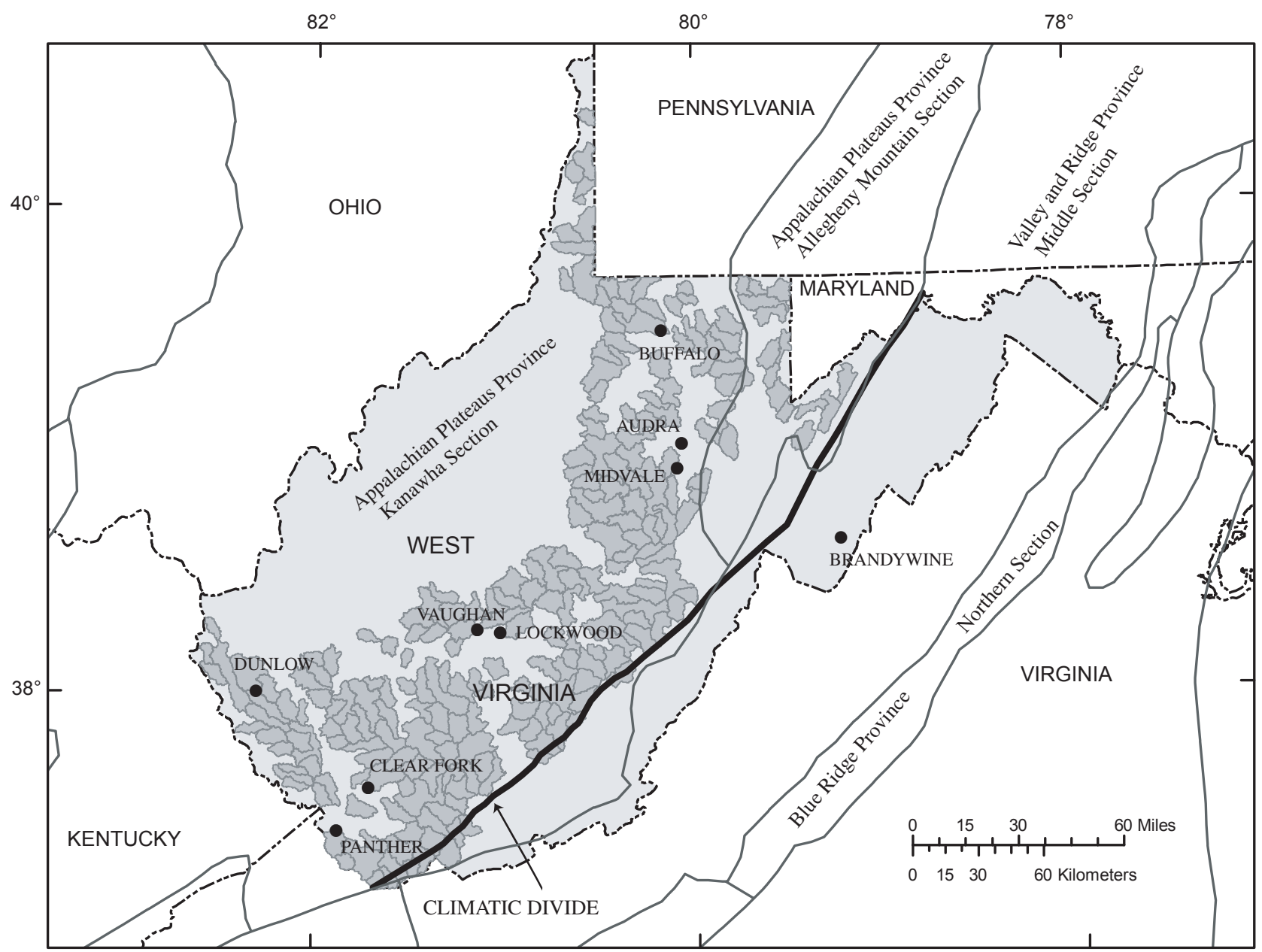

State lines are from the national state line dataset at 1:2,000,000. Physiographic province lines are modified from Fenneman and Johnson, 1946, mapped at the 1:7,000,000 scale. Both datasets are available in digital format at the web site http://permanent.access.gpo.gov/waterusgsgov/ water.usgs.gov/lookup/getgislist.htm. The trend station basin boundaries (darker grey-shaded areas on map) were obtained through Mike Shank, West Virginia Department of Environmental Protection, written commun, (2002). The climatic divide line is from Wiley and others (2000). The map projection is Universal Transverse Mercator, zone 17, and the datum is NAD83 .

Figure 1. Coal-mining region of West Virginia including the eight study basins, the Brandywine Basin, and the 240 basins (darker shaded) where the Hydrologic Simulation Program-FORTRAN Model (HSPF) may be used for cumulative hydrologic impact assessments. 


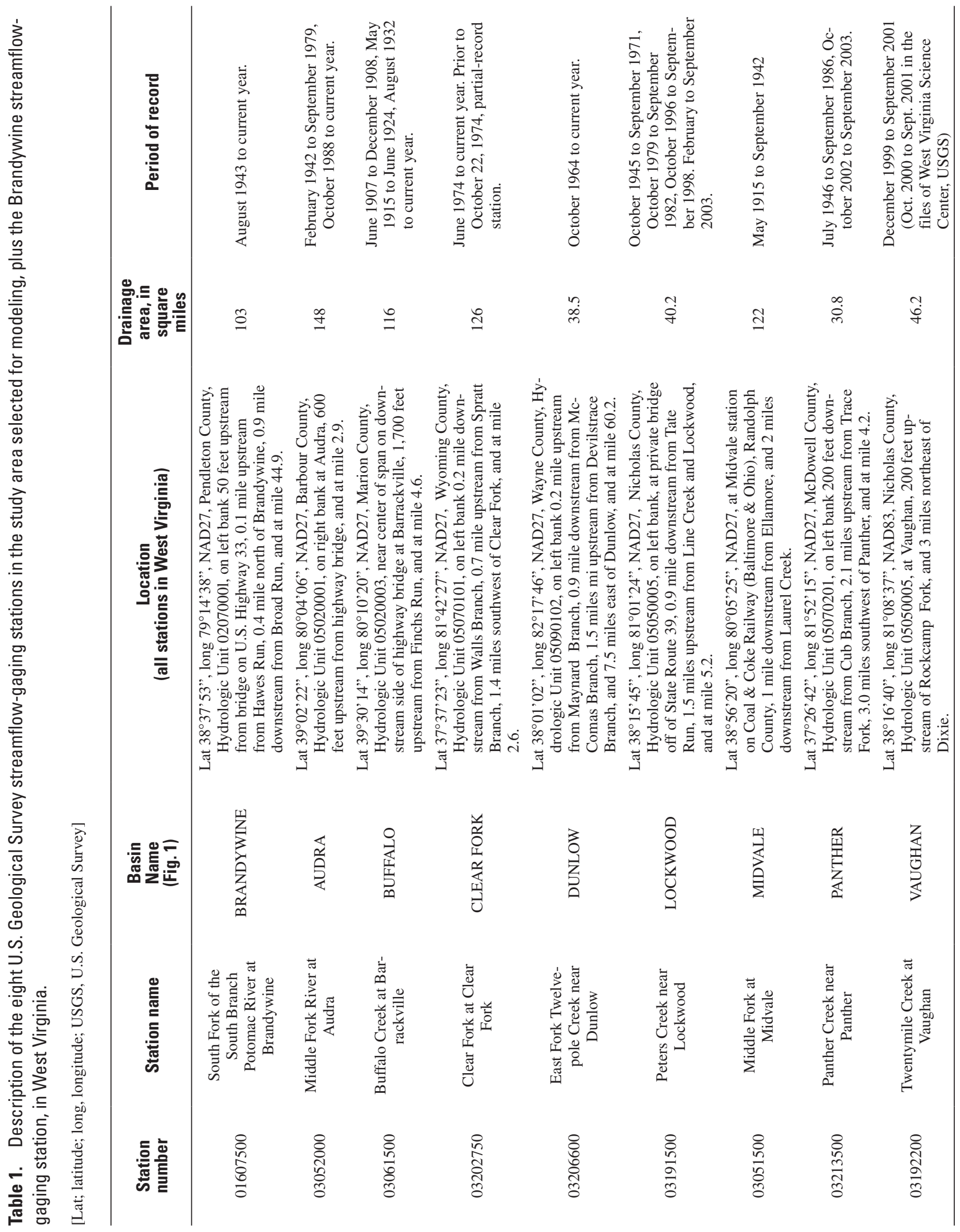


handled essentially all the functions performed by three previous models and has been continuously developed, expanded, and improved to the present (Donigian and Imhoff, 2002). HSPF is the core watershed model in the U.S. Environmental Protection Agency (USEPA) Better Assessment Science Integrating Point and Nonpoint Sources (BASINS) software and the U.S. Army Corps of Engineers (USACE) Watershed Modeling System (WMS). The HSPF model can simulate the hydrologic and associated water-quality processes on pervious and impervious land surfaces, in streams, and for wellmixed impoundments. "HSPF is designed for application to most watersheds using existing meteorologic and hydrologic data" (Bicknell and others, 2001). Persons unfamiliar with the HSPF model may find it helpful to examine the movement of moisture through a land segment as described in appendix A, "Modeling Theory in HSPF."

The HSPF model, Versions 11.1 and 12, both were used in this study. HSPF Version 11.1 was used because it is imbedded in the Expert System for Calibration of HSPF (HSPEXP) Version 2.4 of June 2002, (Kate Flynn, U.S. Geological Survey, oral commun., 2003). HSPF Version 12 (Bicknell and others, 2001) was used for the simulations of basins LOCKWOOD, MIDVALE, and VAUGHAN in order to calculate snow using the new Temperature Index, or degree-day, approach. The degree-day method is summarized by Rango and Martinec, 1995. HSPF simulation runs using Versions 11.1 and 12 for basins AUDRA, BUFFALO, CLEAR FORK, DUNLOW, and PANTHER showed no significant differences and are considered interchangeable.

BASINS software was used to develop the initial User Control Input (UCI) files for the basins in this study. From a BASINS project, the WinHSPF computer program was used to build a WinHSPF project and an initial HSPF simulation. An initial HSPF simulation includes, as a minimum, a Water Data Management (WDM) file and a UCI file. Nominal values for some parameters important to HSPF hydrology calibration are extracted from the "starter.uci" (in BASINS) and deposited into the new UCI file. The BASINS/HSPFParm computer program and data base were not used to develop parameters in the initial UCI file but were useful for comparison purposes.

Five types of digital spatial data are used in BASINS/ WinHSPF to construct a UCI file for an initial HSPF simulation run: (1) elevation data, (2) land-use data, (3) user-specified outlet points (in this case, stream-gage locations), (4) user-specified permeability estimate for urban land-use segments, and (5) user-specified subbasin threshold-area size. For each basin, a description of these is provided in appendix B, "Digital Spatial Data Used for Initial User Control Input (UCI) File Creation."

Time-series data, primarily precipitation and evaporation, are stored in WDM files and are used to drive the HSPF simulation. The sources and uses of precipitation data are summarized in appendix C, "Time-Series Data Used for Initial Water Data Management (WDM) File Creation."

\section{Calibration and Verification of the Streamflow Simulations}

Calibration and verification were achieved by (1) using initial parameter values from a previous nearby model application (BRANDYWINE) (2) using long calibration periods, from 9.75 to 15.75 years, except at VAUGHAN, where it was possible to use only 1.85 years, and (3) examining periods outside the calibration period. The parameters were adjusted based on daily, monthly, and seasonal hydrographs; statistical comparisons; and automated advice from the HSPF Expert System (HSPEXP).

Initial parameter values for the nearby model application at BRANDYWINE were obtained from the Modeling Subcommittee of the Chesapeake Bay Program (CBP) for the USEPA Chesapeake Bay Program Office (CBPO), Annapolis, Md. The CBP Community Watershed Model (CWM) results are in a series of phases: Phase 3 (or III), Phase 4, Phase 5, etc. For this study, the base parameter values of the Phase 3 simulation for the basin with the USGS stream gage 01607500, South Fork of the South Branch Potomac River at Brandywine (BRANDYWINE) were selected. The parameter values and time-series precipitation data for Phase 3 were obtained from Kate Flynn (U.S. Geological Survey, written commun., 2004). Phase 4 time-series precipitation data were downloaded in WDM file format from the U.S. Environmental Protection Agency (2004a) to compare with the Phase 3 parameter values and precipitation data used in this study. HSPF watershed parameters (internally referred to in the subroutine named "PWATER" as "tables" or groups 1-4) are included for Phases 3 and 4 for the Pervious Land Segments (PERLNDs) that apply to BRANDYWINE (PERLNDs $175-176$ in Phase 3 and Phase 4.2 UCI files: base.uci and potm.inp). The Phase 4 parameter values are available in the HSPFParm computer program (Donigian and others, 1999, 2000, or U.S. Environmental Protection Agency, 2004b). Few differences were found between the parameter values and time-series precipitation data for Phases 3 and 4 for BRANDYWINE, and the results of this study would not differ regardless of which of these two Phases were used for creating the initial UCI files.

BRANDYWINE was judged to be the best basin used in the CBP study for reference to this study because of drainage area, proximity, latitude, elevation, and length of streamflow record. The drainage area of BRANDYWINE, $103 \mathrm{mi}^{2}$, is within the range of drainage areas, from $31 \mathrm{mi}^{2}$ to $148 \mathrm{mi}^{2}$, of the basins simulated in this study. BRANDYWINE is about $100 \mathrm{mi}$ east of the basins simulated, but its latitude, about 38.6 degrees, is near the middle of the range of latitude of the basins simulated, from 37.4 to 39.5 degrees. The elevation of BRANDYWINE, $1,558.35 \mathrm{ft}$ gage datum, is within the range of elevations, from $710 \mathrm{ft}$ to $1,812.59 \mathrm{ft}$ gage datums, of the basins simulated. BRANDYWINE has continuous streamflow record since 1943. The major differences between the BRANDYWINE and the eight basins simulated are as follows: 
1. BRANDYWINE is in the Valley and Ridge Physiographic Province, and the basins simulated are in the Appalachian Plateaus.

2. The annual rainfall totals are less for BRANDYWINE than for the simulated basins because BRANDYWINE is affected by a mild rain shadow (note the hypothetical climatic divide line in figure 1 from Wiley and others, 2000).

3. The surficial geology for BRANDYWINE is primarily of Silurian and Devonian age, and the geology for the basins simulated is of Pennsylvanian age.

4. The surficial geology for BRANDYWINE is about 9 percent limestone and limestone/shale, and the eight study sites have only trace amounts of limestone and limestone/ shale.

Once initial simulations were obtained for the eight study basins by use of BASINS, parameter values for PERLNDs that had applied to BRANDYWINE were pasted into the UCI files for the eight basins as comments. All PERLND parameters, matched by land use/land cover with the exception of SLSUR (slope of overland flow plane), were set equal to those of BRANDYWINE. Not all land uses/land covers in the BRANDYWINE application matched the land uses/land covers for this study.

The UCI and WDM files were then modified to enable use of the Expert System for the Calibration of the Hydrological Simulation Program - FORTRAN (HSPEXP) (Lumb and others, 1994). These modifications made each WinHSPF project also an HSPEXP project by methods described by U.S. Environmental Protection Agency (1999). The calibration criteria that the study used within HSPEXP are presented in appendix D, and a complete set of the HSPEXP calibration statistics is presented in appendixes E-L.

The combination of increasing the Impervious Land Segment (IMPLND) area and decreasing the PERLND area is occasionally recommended as part of the HSPEXP seasonal analysis. This recommendation was followed only in the case of BUFFALO because the basin contains the town of Mannington, W.Va., and the initial IMPLND area seemed low. Therefore, 2.0 percent of the drainage area was shifted from the PERLND to the IMPLND area, changing BUFFALO from 1.8 to 3.8 percent of IMPLND area. BASINS calculates the IMPLND for land uses/land covers such as rock outcrops, urban, and others. The percentages of the IMPLND areas calculated by BASINS were not adjusted for any basin except BUFFALO and were 0.1 percent for PANTHER, 0.2 percent for AUDRA, 0.3 percent for MIDVALE, 2.6 percent for CLEAR FORK, 3.6 percent for LOCKWOOD, 4.2 percent for DUNLOW, and 10.5 percent for VAUGHAN.

HSPEXP did not recommend increasing the IMPLND area at CLEAR FORK, although Oceana, W.Va., is an urban area. BASINS calculated the IMPLND area for CLEAR FORK as 2.6 percent compared to 1.8 percent for BUFFALO. Part of the adjustments made to other parameters for CLEAR FORK calibration may be accounted for by not increasing the IMPLND area. Adjustments to the values of LZSN (parameter for the nominal capacity of the lower-zone storage), INFILT (parameter for an index to the infiltration capacity of the soil), LSUR (parameter for the length of the overland flow plane), CEPSC (parameter for interception storage capacity), UZSN (parameter for the nominal capacity of the upper zone storage), NSUR (parameter for Manning's roughness of the land surface), INTFW (parameter for the interflow inflow), and IRC (parameter for the interflow recession constant, ratio of a given day's interflow to the previous day's) were made to calibrate CLEAR FORK. The differences between the values of these eight parameters for CLEAR FORK compared to the values for the parameters of the other basins indicate that increasing the IMPLND area may result in CLEAR FORK parameters being more similar to those of the other basins. The IMPLND area was not increased because the parameters appeared reasonable and met the calibration measures of HSPEXP.

The PERLNDs representing conifer forest, shrubland, barren land, surface water, and wetland land-use/land-cover classifications were less than or equal to 2.0 percent of the total areas for the eight basins, and these land-use/land-cover classifications were not used in the simulation of BRANDYWINE. Therefore, these parameter values were set equal to or similar to those representing the hardwood forest classification for BRANDYWINE.

\section{Calibration Results}

Annual analysis. - Rainfall and runoff for the study area would be expected to exceed the statewide average, and evaporation would be expected to be less than the statewide average because of the higher elevation of the study area compared to the average elevation of the State. Evaporation decreases with increasing elevation, according to Farnsworth and others (1982). The magnitude of elevation effects is evident for the weather station PICKENS $2 \mathrm{~N}$, which is at an elevation of 2,880 and has about 40-percent greater precipitation than the statewide average. (The AUDRA and MIDVALE basin boundary is near PICKENS 2 N.)

The average annual precipitation for West Virginia is about 44 in. (data covering 1897-1996, National Oceanic and Atmospheric Administration, 1996). In a study of runoff in eastern states including West Virginia, Krug and others (1990) reported six stations in West Virginia that average 23.5 in. of runoff for the period 1951-80. The mean of the average of annual precipitation for reporting gages during the period 1951-80 (table 2, fig. 2) is 43.53 in. The runoff of $23.5 \mathrm{in}$. from 43.52 in. of precipitation is approximately 54 percent. Hobba and Suder (1987) estimated 47-percent runoff.

Runoff characteristics for the eight basins model-simulated in this study were compared to the runoff characteristics of the five basins modeled by Puente and Atkins (1989) to assess the reasonableness of simulation results (table 3 ). The five basins are within the southern half of this study area. Puente and Atkins used the Precipitation-Runoff Modeling System (PRMS) developed by Leavesley and others (1983). Average annual precipitation was about 40-50 in., average 
Table 2. Average of annual precipitation for reporting stations in West Virginia from 1931 through 1997.

[Data accessed July 20, 2004, at URL http://www1.ncdc.noaa.gov/pub/data/coop-precip/west-virginia.txt]

\begin{tabular}{|c|c|c|c|c|c|c|c|}
\hline Year & $\begin{array}{c}\text { Number of } \\
\text { stations } \\
\text { reported } \\
\text { with annual } \\
\text { total }\end{array}$ & $\begin{array}{l}\text { Average of } \\
\text { annual precipita- } \\
\text { tion at report- } \\
\text { ing stations, in } \\
\text { inches }\end{array}$ & $\begin{array}{c}\text { Departure } \\
\text { from mean } \\
\text { of average } \\
\text { of annual } \\
\text { precipitation } \\
\text { at reporting } \\
\text { stations for } \\
\text { period of } \\
\text { record, in } \\
\text { percent }\end{array}$ & Year & $\begin{array}{l}\text { Number of } \\
\text { stations } \\
\text { reported } \\
\text { with an- } \\
\text { nual total }\end{array}$ & $\begin{array}{l}\text { Average of an- } \\
\text { nual precipita- } \\
\text { tion at reporting } \\
\text { stations, in } \\
\text { inches }\end{array}$ & $\begin{array}{c}\text { Departure } \\
\text { from mean } \\
\text { of average } \\
\text { of annual } \\
\text { precipitation } \\
\text { at reporting } \\
\text { stations for } \\
\text { period of } \\
\text { record, in } \\
\text { percent }\end{array}$ \\
\hline 1931 & 76 & 41.9 & -5.4 & 1965 & 106 & 34.9 & -21.3 \\
\hline 1932 & 79 & 43.5 & -1.8 & 1966 & 103 & 38.3 & -13.6 \\
\hline 1933 & 81 & 48.2 & 8.9 & 1967 & 101 & 44.6 & .7 \\
\hline 1934 & 79 & 37.6 & -15.2 & 1968 & 97 & 39.0 & -11.9 \\
\hline 1935 & 80 & 50.6 & 14.3 & 1969 & 106 & 38.7 & -12.7 \\
\hline 1936 & 82 & 42.2 & -4.8 & 1970 & 98 & 41.7 & -6.0 \\
\hline 1937 & 86 & 50.2 & 13.2 & 1971 & 92 & 42.6 & -3.8 \\
\hline 1938 & 92 & 42.2 & -4.6 & 1972 & 88 & 55.2 & 24.7 \\
\hline 1939 & 98 & 43.4 & -2.0 & 1973 & 84 & 46.7 & 5.5 \\
\hline 1940 & 101 & 44.9 & 1.3 & 1974 & 80 & 47.6 & 7.4 \\
\hline 1941 & 109 & 36.1 & -18.6 & 1975 & 75 & 51.3 & 15.7 \\
\hline 1942 & 118 & 48.5 & 9.6 & 1976 & 66 & 41.6 & -6.1 \\
\hline 1943 & 116 & 40.6 & -8.4 & 1977 & 60 & 41.4 & -6.6 \\
\hline 1944 & 122 & 45.1 & 1.8 & 1978 & 65 & 47.7 & 7.7 \\
\hline 1945 & 118 & 50.7 & 14.5 & 1979 & 58 & 52.5 & 18.5 \\
\hline 1946 & 116 & 36.9 & -16.7 & 1980 & 60 & 45.3 & 2.2 \\
\hline 1947 & 122 & 37.1 & -16.3 & 1981 & 64 & 44.0 & -.7 \\
\hline 1948 & 104 & 52.2 & 17.9 & 1982 & 73 & 44.9 & 1.4 \\
\hline 1949 & 115 & 44.9 & 1.5 & 1983 & 68 & 44.0 & -.6 \\
\hline 1950 & 98 & 54.0 & 22.0 & 1984 & 70 & 45.9 & 3.7 \\
\hline 1951 & 106 & 47.9 & 8.1 & 1985 & 59 & 46.2 & 4.2 \\
\hline 1952 & 102 & 41.3 & -6.8 & 1986 & 67 & 43.2 & -2.5 \\
\hline 1953 & 117 & 36.6 & -17.5 & 1987 & 60 & 39.3 & -11.3 \\
\hline 1954 & 92 & 46.4 & 4.8 & 1988 & 64 & 35.7 & -19.5 \\
\hline 1955 & 95 & 39.3 & -11.2 & 1989 & 50 & 52.0 & 17.3 \\
\hline 1956 & 92 & 51.0 & 15.2 & 1990 & 49 & 50.7 & 14.5 \\
\hline 1957 & 91 & 41.3 & -6.8 & 1991 & 46 & 42.1 & -4.9 \\
\hline 1958 & 96 & 45.4 & 2.5 & 1992 & 44 & 41.8 & -5.5 \\
\hline 1959 & 95 & 39.7 & -10.4 & 1993 & 39 & 44.7 & .8 \\
\hline 1960 & 85 & 38.8 & -12.4 & 1994 & 58 & 49.2 & 11.1 \\
\hline 1961 & 78 & 48.6 & 9.8 & 1995 & 41 & 44.4 & .3 \\
\hline 1962 & 94 & 43.7 & -1.4 & 1996 & 41 & 61.0 & 37.8 \\
\hline 1963 & 101 & 37.0 & -16.5 & 1997 & 40 & 42.0 & -5.1 \\
\hline 1964 & 103 & 39.8 & -10.2 & & & & \\
\hline
\end{tabular}

annual deep infiltration was less than 6 in., and average annual runoff was about 20-35 in. for basins modeled in both studies. Average annual evapotranspiration was about 20-25 in. for basins in both studies except for AUDRA and BUFFALO in this study, where averages of annual evapotranspirations were 13.4 and 13.9 in., respectively. These seemingly low values are reasonable in view of two factors. First, contour maps developed by Farnsworth and others (1982) indicate that AUDRA is in an area of low evaporation. Second, the calibration period for AUDRA, 1970-79, is in a period of low evaporation as compared to the period used to produce the contours in Farnsworth and others (1982), 1956-70. When these periods were compared at four weather stations, average computed evaporations were found to be higher at each station for the period 1956-70 than for 1970-79; the stations were "Elkins - Randolph County Airport, WV," "WilliamsportLycoming County, PA," "Roanoke Regional Airport, VA," and "Lynchburg, VA" (National Oceanic and Atmospheric 


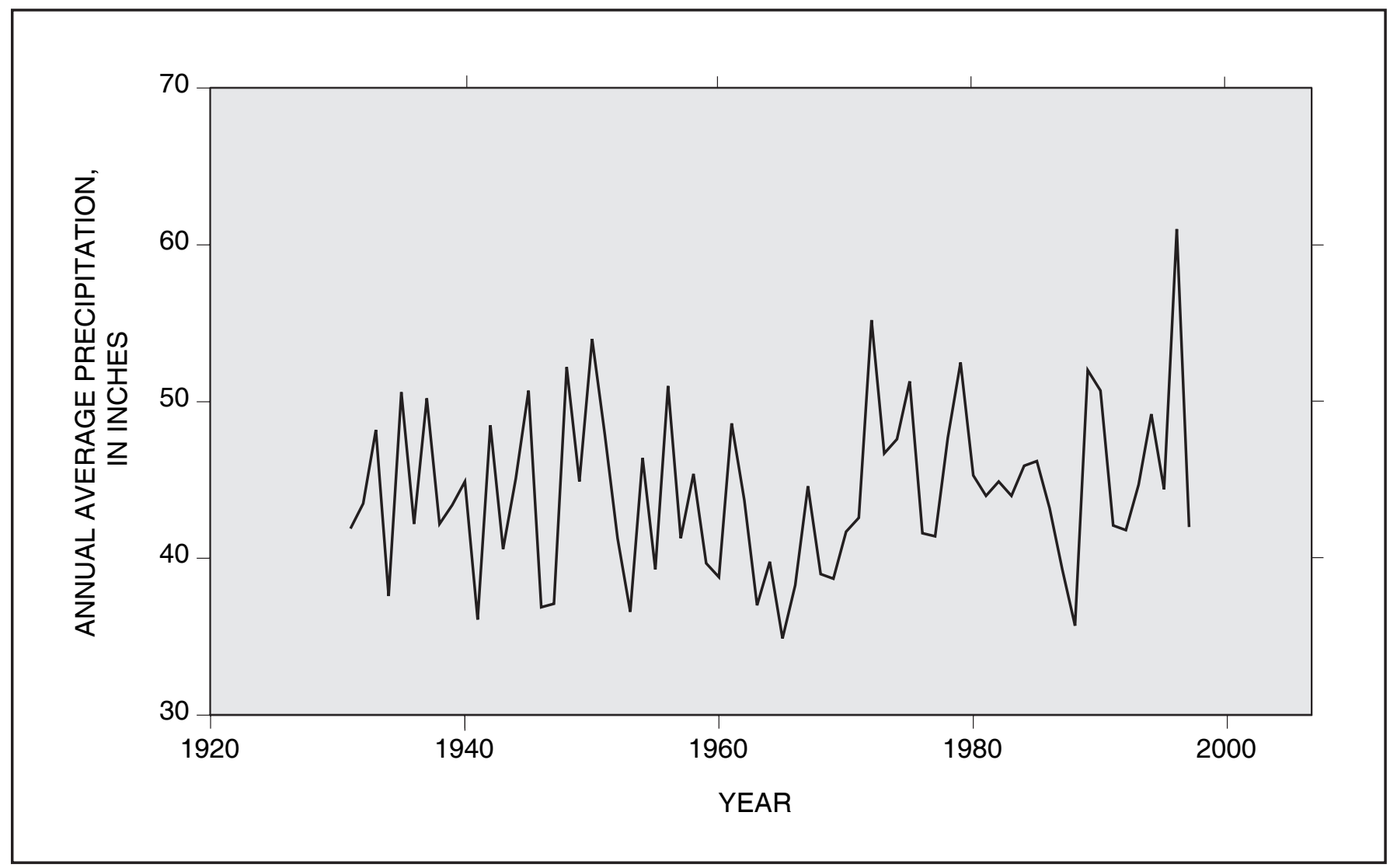

Figure 2. Average of annual precipitation for reporting stations in West Virginia from 1931 through1997.

Administration, 2001 or see Duan and others, 2003). Conversely, the greatest percentage of average annual runoff was determined for AUDRA, which was about 10 percent greater than the 40 to 60 (38.7 to 61.3 in table 3 ) percent range for the other basins. The percentage of average annual runoff for BUFFALO (61.3) was at the high side of the 40- to 60-percent range.

Seasonal analysis. - Seasonal analysis was one guiding factor in calibration. A summary of seasonal precipitation and evaporation/evapotranspiration data are presented in appendix C, where HSPEXP designated summer as June through August and winter as December through February. Hydrographs of daily simulated and observed streamflows (appendix M) were examined as part of a seasonal analysis. The outcome from hydrograph examination was frequently used for guidance in calibration, occasionally overriding the guidance from HSPEXP.

The calibration process resulted in as many as five parameters being specified as having monthly variations with strong seasonal characteristics. Monthly variations of parameter values for the PERLND representing hardwood forests are presented for CEPSC, NSUR, UZSN, LZETP (parameter for lower zone evapotranspiration), and DEEPFR (parameter for the fraction of ground-water inflow that flows to inactive ground water) in table 4 . The parameter values were gener- ally lowest in winter and spring and highest in summer and autumn. Monthly variations of CEPSC, UZSN, and LZETP were applied to the PERLND representing forests for all basins, and monthly variations of NSUR were applied to the PERLND representing forests for only DUNLOW. Parameter values for VUZFG (parameter indicating whether upper-zone nominal storage is considered in the simulation) and VNNFG (parameter indicating whether Manning's roughness for the land surface is considered in the simulation) indicate the PERLNDs where monthly variations were applied (table 6). The simulation of BRANDYWINE by CBPO did not apply monthly variations of UZSN, LZETP, NSUR, or DEEPFR to the PERLND representing forests.

Summer. - The summer period, as designated by the HSPEXP statistical output, is June through August. It was difficult to simulate the lowest summer streamflows, and the lowest streamflows are where dissolved concentrations of chemical constituents are typically the greatest. Simulation results were viewed on semi-logarithmic hydrographs to emphasize the lowest flows. Lowest flows on linear hydrographs are nearly invisible because they plot too near the time axis.

Winter.- The winter period in the HSPEXP statistical output is December through February. It was difficult to obtain winter runoff sufficiently high for all eight basins. Snow was simulated for all PERLNDs with a snow gage catch correc- 


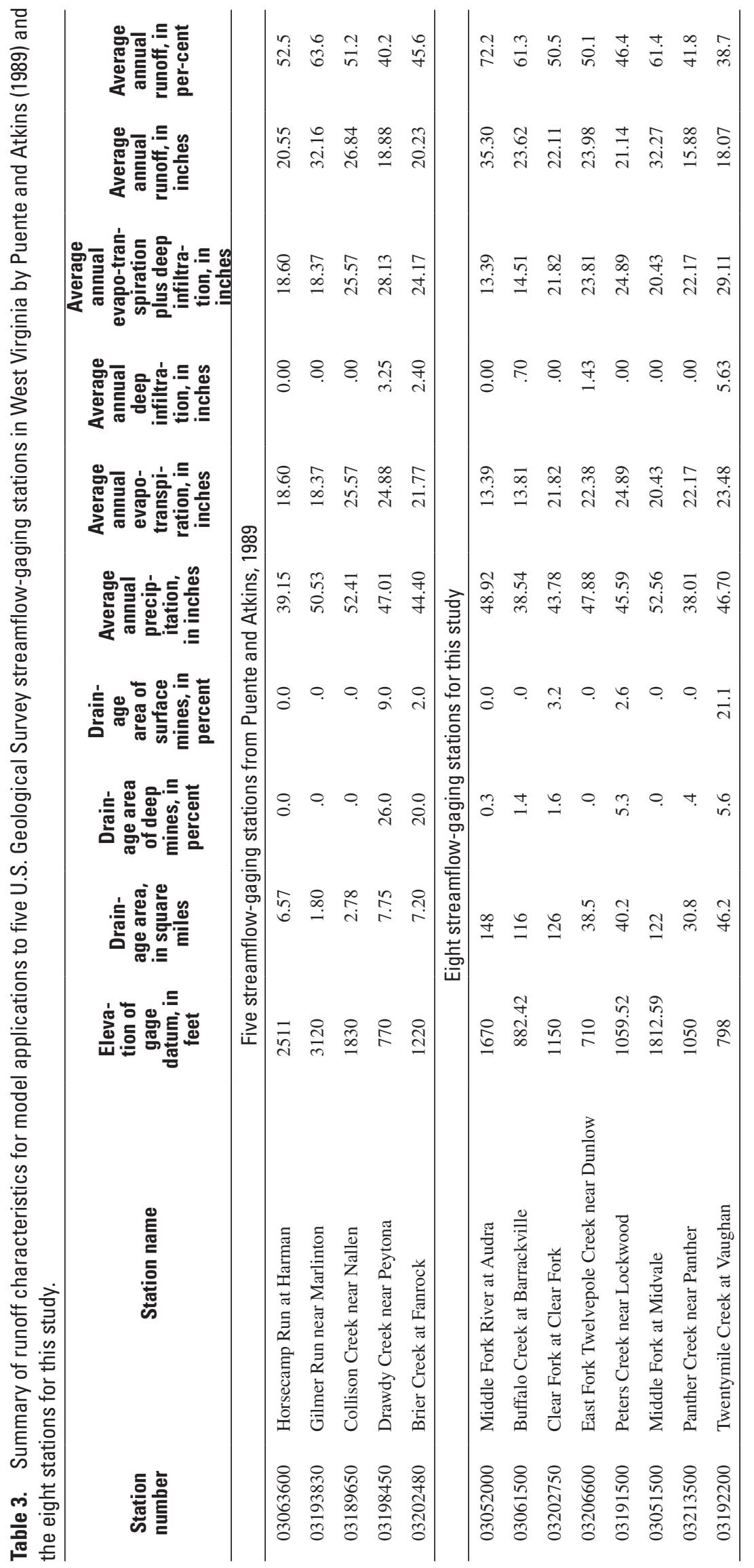




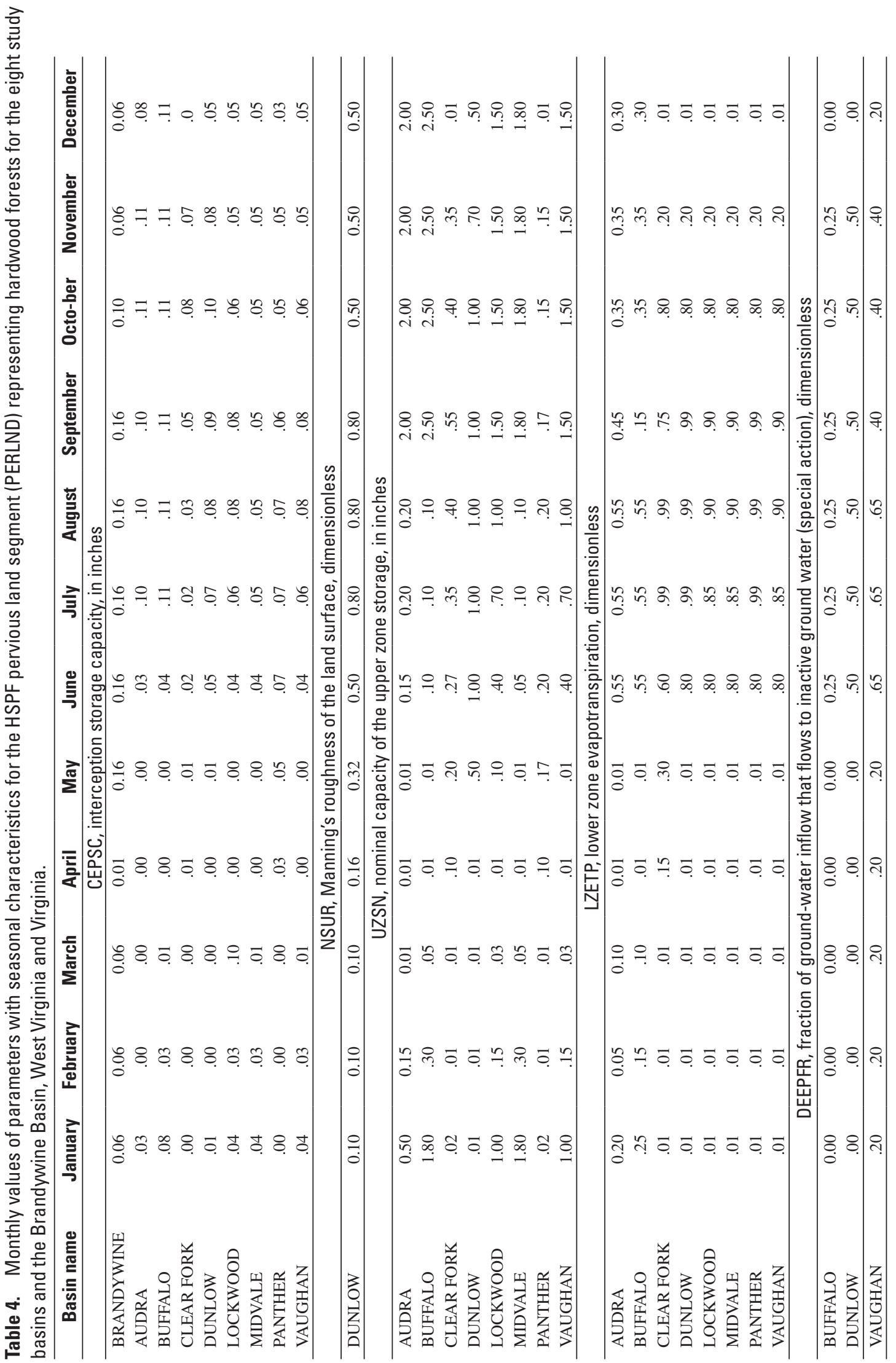


tion factor (SNOWCF) of 1.5, although results indicate a higher value would have led to better calibrations. The value of SNOWCF was not increased because it was at the high end of the values suggested by BASINS Technical Note 6 (U.S. Environmental Protection Agency, 2000) and the calibration met the measures of HSPEXP. The value of SNOWCF is at the high range of the variability indicated by other HSPF calibrations.

Spring.- The spring period in the HSPEXP statistical output is March through May. The best fit was obtained by use of gradually increasing the values of CEPSC, UZSN, and LZETP through spring (table 4).

Autumn.- Acceptable results were obtained for the lowest daily simulated streamflows, but with some difficulty. (See appendix M for HSPEXP calibration hydrographs for the eight study basins.) It was especially difficult to calibrate the autumn period, September through November, for BUFFALO and VAUGHAN, and the unmined period for DUNLOW; for these sites, the special actions capability of HSPF was applied.

The standard use of the DEEPFR parameter is as a simple nonvarying parameter to control water loss to inactive ground water. DEEPFR is typically the last parameter set during calibration and will typically include any other losses not accounted for in model simulation. Higher elevations of a watershed are likely to lose more water to deep ground water than lower elevations of a watershed (Freeze and Cherry, 1979, section 6.1). Calibration of a constant value for DEEPFR of greater than zero resulted in a simulation that underestimated streamflow in winter. A special action of varying DEEPFR to a value greater than zero in the autumn for mined basins BUFFALO and VAUGHAN and for the unmined period of DUNLOW was used for calibration.
The hydrologic basis for varying DEEPFR is based on the attempt to simulate an underground moisture deficit that results from seasonal movement of the water table and transpiration by trees. Internally, mountains are chiefly characterized by unsaturated zones, voids that are sometimes flooded or floodable. As the schematic in figure 3 depicts, the tops of mountains have large unsaturated zones. Voids are recharged during extended wet periods principally during winter and spring. Trees are mostly finished growing by midsummer (John Robards, Natural Resource Analysis Center, oral commun., 2003). Trees, however, continue to transpire; only a small fraction of the water that the trees absorb goes to photosynthesis or into growth of the plant itself. Transpiration is able to draw from ground water that does not contribute to runoff because it is perched, below, or outside the drainable (to stream gage) volume. (Perched ground water is separated from the main body of ground water by a confining impervious layer.) Transpiration also draws from moisture encapsulated inside the root volume of trees. Shallow vegetation wilts during droughts in West Virginia, but large trees very rarely wilt because trees do not become large without having found a steady water supply. Sap begins running midwinter to early spring, having a negligible effect on the rainfall-runoff relation because of ample water storage in the unsaturated zone. Transpiration from trees continues until autumn as, gradually and competitively, trees expend water from their individual influence zones in the unsaturated zone and below. After midsummer, a much dryer unsaturated zone begins to influence the rainfall-runoff relation because there are voids that can be filled. In late summer, transpiration by trees begins to lower water levels in the zone below the active ground-water zone. The voids that can be filled from the downward movement of

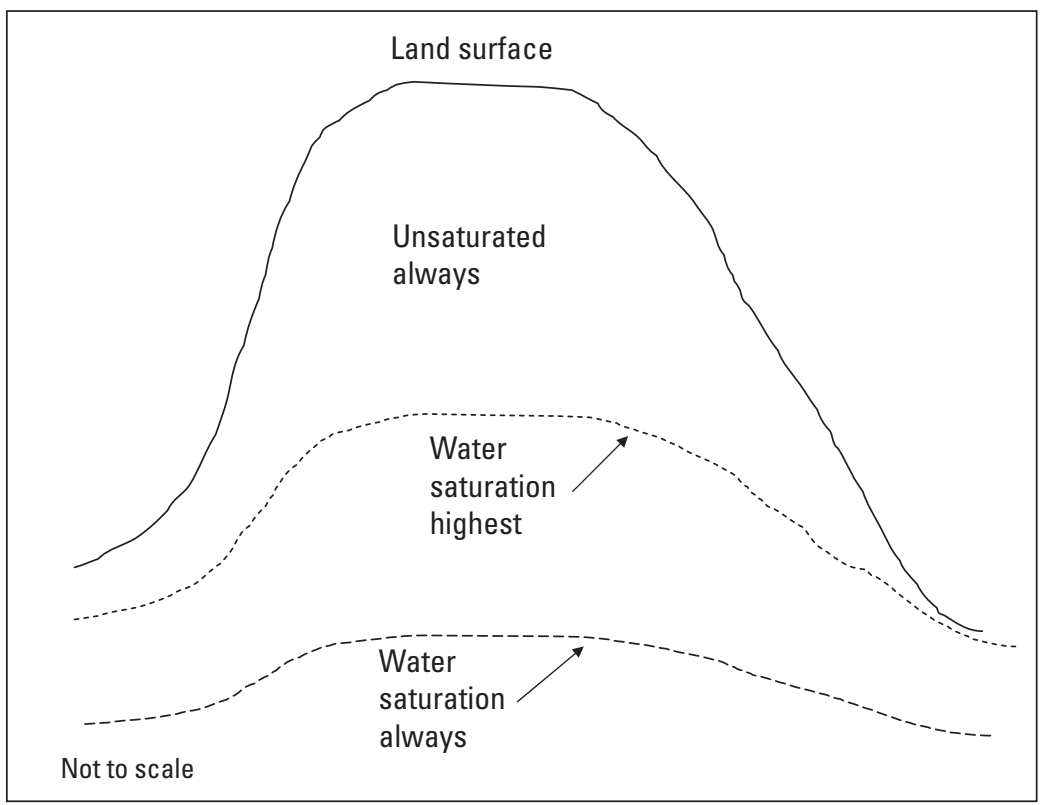

Figure 3. Generalized variation of the water table and the unsaturated zone beneath a mountain. 
the active ground water is simulated by increasing DEEPFR to a value greater than zero during autumn (fig. 4). In late autumn or early winter, the zone below the active ground water is again saturated, and the downward movement from the active ground water is no longer possible, as simulated by the value of DEEPFR returning to zero.

Hourly analysis. - High hourly intensities of precipitation measured at a rain gage are not likely to apply to a large watershed. To examine the characteristic intensity of each input time series, a measure of hourly intensity was devised by counting the number of times that the hourly rainfall exceeded $0.5 \mathrm{in}$. of precipitation and dividing by the years considered (table 5). For comparison, 3.5 annual events exceeding 0.5 in/h intensity were observed at the National Weather Service (NWS) precipitation gage at the NWS office at the airport at Beckley, W.Va. (BECKLEY WSO AP). Also of interest is the precipitation time series that had been applied to BRANDYWINE by CBP; it was derived by area averaging as described in the section "Sources of Precipitation Data" in appendix C.

Daily observed precipitation was disaggregated to hourly values at LOCKWOOD, MIDVALE, and VAUGHAN. These hourly time series required smoothing by computing 4-hour averages to make them less intense than observed hourly precipitation, to make them more similar to precipitation data provided by Natural Resource Analysis Center (NRAC) for the other basins, and to make their intensities similar to that of BRANDYWINE. Hourly intensities before and after smoothing are presented in table 5.

An analysis of model calibration results determined that the value for the parameter INFILT was related to the intensity of precipitation data used in the specific calibration period. Comparing the simulations at LOCKWOOD and MIDVALE before and after smoothing precipitation indicates the values for INFILT increase as the number of annual events exceeding $0.5 \mathrm{in} / \mathrm{h}$ increases. This effect did not appear at VAUGHN probably because the value for INFLT was already high, the highest value for INFILT in this study. Increase in value for INFILT because of increase in rainfall intensity may be an effect limited to the study area, however, because it is not found at BRANDYWINE. At BRANDYWINE for Phase 3 (dataset number 702 in table 5) and Phase 4 (dataset number 1170), the value for INFILT decreases as the number of annual events exceeding $0.5 \mathrm{in} / \mathrm{h}$ increases.

All pan evaporation (EVAP) and potential-evapotranspiration (PEVT) hourly time series used at seven of the sites consisted of a series of spikes, dropping suddenly to zero at sundown and rising stepwise at sunrise. Spikes of this kind were not visible in final hydrographs except at DUNLOW. For DUNLOW, because flows were very low, an oscillation was visible in the hydrograph that was traced to these spikes. To avoid this distraction, daily values of potential evapotranspiration (DEVT) were used in HSPF ("DIV" data-set option).

Examination of precipitation intensity also helps interpretation of the final results. A degree of skepticism with regards to short-period hydrographs is proper, because of the general problem of fitting point rainfall values to a large area (Hershfield, 1961; Chow, 1964). Calibration was continued until a fairly good streamflow estimator was developed, as evidenced by the appearance of hydrographs covering many years and by calibration statistics (table 6). HSPEXP calibration hydrographs for the eight study basins are presented in appendix $\mathrm{M}$. The coefficient of determination, $\mathrm{r}^{2}$, was computed for the simulated and observed $\log _{10}$-transformed streamflows as a measure of fit between the two hydrographs plotted on semilogarithmic plot. The average $\mathrm{r}^{2}$ was 0.642 for the calibrations. The base-flow recession rate was another statistic used for model calibration, and all calibrations met the base-flow recession rate criterion of 0.01 .

All calibrations were within the criteria for total runoff (10 percent) and total stormflow runoff (15 percent). For the six study basins that were also verified, the median springcalibration error was -8.3 percent, ranging from -20.2 to

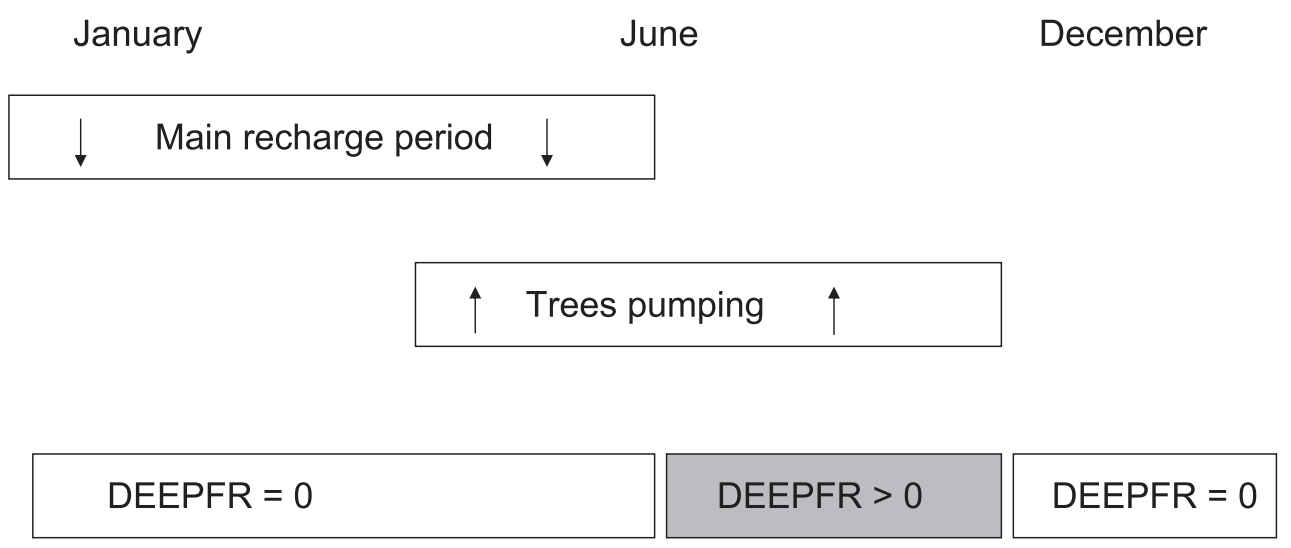

Figure 4. Recharge, tree transpiration, and the fraction of ground-water inflow that flows to inactive ground water (DEEPFR) in Hydrologic Simulation Program-FORTRAN Model (HSPF) simulation. 
Table 5. Precipitation intensity and infiltration for the eight study basins and the Brandywine Basin, West Virginia and Virginia.

[DSN, dataset number; WDM, water data management file; INFILT, parameter for an index to the infiltration capacity of the soil; PERLND, pervious land segment; - - - , no value]

\begin{tabular}{|c|c|c|c|c|c|}
\hline \multirow{2}{*}{$\begin{array}{l}\text { Basin name } \\
\text { (Fig. 1) }\end{array}$} & \multirow[b]{2}{*}{ DSN in WDM } & \multicolumn{2}{|c|}{$\begin{array}{l}\text { Number of annual events exceeding } \\
0.5 \text { inch per hour intensity }\end{array}$} & \multicolumn{2}{|c|}{$\begin{array}{c}\text { Number of annual events exceeding } \\
0.5 \text { inch per hour intensity prior to } \\
\text { averaging (smoothing) }\end{array}$} \\
\hline & & Number per year & $\begin{array}{l}\text { INFILT for the } \\
\text { major PERLND, } \\
\text { hardwood forest, } \\
\text { in inches per day }\end{array}$ & Number per year & $\begin{array}{l}\text { INFILT for the } \\
\text { major PERLND, } \\
\text { hardwood forest, } \\
\text { in inches per day }\end{array}$ \\
\hline \multirow{2}{*}{ BRANDYWINE } & 702 & 1.80 & 0.04050 & --- & -- \\
\hline & 1170 & 2.20 & .03000 & - - - & - - - \\
\hline AUDRA & 70 & .00 & .04050 & --- & -- \\
\hline BUFFALO & 327 & .00 & .02900 & $-\ldots$ & - - - \\
\hline CLEAR FORK & 3011 & .00 & .03500 & - - - & - - - \\
\hline DUNLOW & 33 & .25 & .03000 & -- & -- \\
\hline LOCKWOOD & 56 & .75 & .03000 & 5.50 & 0.04050 \\
\hline MIDVALE & 58 & 1.40 & .08100 & 2.40 & .10125 \\
\hline PANTHER & 247 & .25 & .03037 & - - - & - - - \\
\hline VAUGHAN & 56 & .75 & .12200 & 5.50 & .12200 \\
\hline
\end{tabular}

-0.1 percent; the median summer-calibration error was 10.3 percent, ranging from 6.0 to 15.1 percent; the median autumncalibration error was -12.7 percent, ranging from -46.6 to 32.1 percent; and the median winter-calibration error was 7.4 percent, ranging from -2.8 to 19.9 percent.

\section{Verification Results}

Model verification was done on six of the eight study basins with good results. Verification was not done on two sites: VAUGHN because there was no additional streamflow data that had not been used for calibration and PANTHER because there was no additional meteorological data identical to that used for calibration. Model verification was measured by comparing selected streamflow statistics between the simulated and observed streamflows for the calibrated record period and the verified record period (table 6).

The $\mathrm{r}^{2}$ for the relation between simulated and observed $\log _{10}$-transformed streamflow was 0.646 for the verifications, and it exceed the $\mathrm{r}^{2}$ for the calibration at three of the six study basins. The verification results for five study basins met the stormflow runoff calibration criterion of 15 percent, and the verification of four study basins met the calibration criterion for total runoff of 10 percent. Verification results for BUFFALO did not meet, but were near, the calibration criterion for total runoff at 11.6 percent. Verification results for CLEAR FORK did not meet the calibration criteria for either total runoff, 27.3 percent, or total stormflow runoff, 45.9 percent. Poor verification results for CLEAR FORK were perhaps because of continued mining or continued development, but more likely were merely a result of an upward trend in the rainfall time-series. Comparing the verification and calibration periods (table 6) on a daily basis, the rainfall time-series (appendix C) was about 6.8 percent higher, while observed streamflow averaged about 14 percent lower.

The base-flow recession rate was another statistic used to verify the model results. Verifications for four of the study basins met the calibration criterion. Verifications at CLEAR FORK and MIDVALE did not meet the criterion, but the error for base-flow recession rate was only 0.02 .

Verification seasonal errors were similar to calibration seasonal errors. The median spring verification error was -2.7 percent, ranging from -11.6 to 4.8 percent; the median summer verification error was 27.2 percent, ranging from -30.4 to 64.9 percent; the median autumn verification error was -11.3 percent, ranging from -27.4 to 97.8 percent; and the median winter verification error of 10.8 percent, ranging from 3.1 to 26.6 percent. 
Table 6. Summary statistics for model calibration and verification used in this study.

[Coefficient of determination is the comparison between the simulated and observed log 10 streamflows; Stormflow runoff is the total runoff volume of the streamflows with a 10-percent or less chance of being equaled or exceeded; Base-flow runoff is the total runoff volume of the streamflows with a 50-percent or greater chance of being equaled or exceeded; Spring is March through May; Summer is June through August; Autumn is September through November; Winter is December through February; a positive error indicates the simulated statistic is greater than the observed statistic; a negative error indicates the simulated statistic is less than the observed statistic; --, no value]

\begin{tabular}{|c|c|c|c|c|c|c|c|}
\hline \multirow[b]{2}{*}{ Summary statistic } & \multicolumn{4}{|c|}{ Calibration } & \multicolumn{3}{|c|}{ Verification } \\
\hline & $\begin{array}{l}\text { Simulated, in } \\
\text { inches over } \\
\text { the drainage } \\
\text { area }\end{array}$ & $\begin{array}{l}\text { Observed, in } \\
\text { inches over } \\
\text { the drainage } \\
\text { area }\end{array}$ & $\begin{array}{l}\text { Error, in } \\
\text { percent }\end{array}$ & $\begin{array}{c}\text { Criterion, in } \\
\text { percent }\end{array}$ & $\begin{array}{l}\text { Simulated, in } \\
\text { inches over } \\
\text { the drainage } \\
\text { area }\end{array}$ & $\begin{array}{l}\text { Observed, in } \\
\text { inches over } \\
\text { the drainage } \\
\text { area }\end{array}$ & $\begin{array}{l}\text { Error, in } \\
\text { percent }\end{array}$ \\
\hline \multicolumn{8}{|c|}{$\begin{array}{l}03052000 \text { Middle Fork River at Audra (AUDRA) } \\
\text { lary 1, 1970, to September 30, 1979; coefficient of determination is } 0.624 \\
\text { ay 28,1988, to September 30,1995; coefficient of determination is } 0.644\end{array}$} \\
\hline Total runoff & 344 & 351 & -1.8 & 10 & 239 & 237 & 0.6 \\
\hline Total stormflow runoff & 145 & 142 & 2 & 15 & 106 & 104 & 2 \\
\hline Total base-flow runoff & 45 & 43 & 3.5 & - & 27 & 22 & 18.7 \\
\hline Total spring runoff & 93 & 116 & -20.2 & -- & 82 & 93 & -11.6 \\
\hline Total summer runoff & 52 & 45 & 15.1 & -- & 38 & 30 & 26.9 \\
\hline Total autumn runoff & 45 & 50 & -10.3 & -- & 26 & 25 & 5.6 \\
\hline Total winter runoff & 155 & 139 & 11.0 & - & 92 & 90 & 3.1 \\
\hline
\end{tabular}

03061500 Buffalo Creek at Barrackville (BUFFALO)

Calibration period: January 1, 1970, to December 31, 1980; coefficient of determination is 0.595

Verification period: January 1, 1981, to September 30, 1995; coefficient of determination is 0.655

\begin{tabular}{lrrrrrrr}
\hline Total runoff & 260 & 260 & 0 & 10 & 316 & 284 & 11.6 \\
Total stormflow runoff & 132 & 129 & 2.4 & 15 & 166 & 151 & 9.9 \\
Total base-flow runoff & 24 & 24 & -3.8 & -- & 26 & 21 & 24.1 \\
Total spring runoff & 82 & 91 & -9.2 & -- & 118 & 113 & 4.3 \\
Total summer runoff & 41 & 36 & 12.7 & -- & 43 & 28 & 50.2 \\
Total autumn runoff & 18 & 34 & -46.6 & -- & 24 & -21.8 & 111 \\
Total winter runoff & 119 & 99 & 19.9 & -- & 131 & 18.4 \\
\hline
\end{tabular}

03202750 Clear Fork at Clear Fork (CLEAR FORK)

Calibration period: June 28,1974, to June 27, 1984; coefficient of determination is 0.634

Verification period: June 28, 1984, to September 30, 1995; coefficient of determination is 0.674

\begin{tabular}{|c|c|c|c|c|c|c|c|}
\hline Total runoff & 221 & 222 & -0.2 & 10 & 272 & 214 & 27.3 \\
\hline Total stormflow runoff & 117 & 109 & 7.1 & 15 & 153 & 105 & 45.9 \\
\hline Total base-flow runoff & 25 & 21 & 17.1 & -- & 24 & 18 & 33.1 \\
\hline Total spring runoff & 81 & 90 & -10.1 & -- & 93 & 89 & 4.8 \\
\hline Total summer runoff & 32 & 30 & 6.0 & - & 30 & 18 & 64.9 \\
\hline Total autumn runoff & 33 & 25 & 32.1 & -- & 39 & 20 & 97.8 \\
\hline Total winter runoff & 75 & 76 & -1.7 & - & 110 & 87 & 26.6 \\
\hline
\end{tabular}


Table 6. Summary statistics for model calibration and verification used in this study.-Continued

[Coefficient of determination is the comparison between the simulated and observed $\log 10$ streamflows; Stormflow runoff is the total runoff volume of the streamflows with a 10-percent or less chance of being equaled or exceeded; Base-flow runoff is the total runoff volume of the streamflows with a 50-percent or greater chance of being equaled or exceeded; Spring is March through May; Summer is June through August; Autumn is September through November; Winter is December through February; a positive error indicates the simulated statistic is greater than the observed statistic; a negative error indicates the simulated statistic is less than the observed statistic; --, no value]

\begin{tabular}{|c|c|c|c|c|c|c|c|}
\hline \multirow[b]{2}{*}{ Summary statistic } & \multicolumn{4}{|c|}{ Calibration } & \multicolumn{3}{|c|}{ Verification } \\
\hline & $\begin{array}{l}\text { Simulated, in } \\
\text { inches over } \\
\text { the drainage } \\
\text { area }\end{array}$ & $\begin{array}{l}\text { Observed, in } \\
\text { inches over } \\
\text { the drainage } \\
\text { area }\end{array}$ & $\begin{array}{l}\text { Error, in } \\
\text { percent }\end{array}$ & $\begin{array}{l}\text { Simulated, in } \\
\text { inches over } \\
\text { the drainage } \\
\text { area }\end{array}$ & $\begin{array}{l}\text { Observed, in } \\
\text { inches over } \\
\text { the drainage } \\
\text { area }\end{array}$ & $\begin{array}{l}\text { Error, in } \\
\text { percent }\end{array}$ & $\begin{array}{l}\text { Simulated, in } \\
\text { inches over } \\
\text { the drainage } \\
\text { area }\end{array}$ \\
\hline \multicolumn{8}{|c|}{$\begin{array}{l}03206600 \text { East Fork Twelvepole Creek near Dunlow (DUNLOW) } \\
\text { Calibration period: January 1, 1970, to December 31, 1979; coefficient of determination is } 0.729 \\
\text { Verification period: January 1, 1980, to September 30, 1995; coefficient of determination is } 0.725\end{array}$} \\
\hline Total runoff & 240 & 235 & 1.9 & 10 & 278 & 283 & -1.7 \\
\hline Total stormflow runoff & 131 & 130 & .7 & 15 & 161 & 154 & 4 \\
\hline Total base-flow runoff & 22 & 16 & 37.5 & - & 17 & 16 & 6.8 \\
\hline Total spring runoff & 91 & 91 & -.1 & -- & 119 & 120 & -.9 \\
\hline Total summer runoff & 23 & 22 & 6.5 & - & 22 & 31 & -30.4 \\
\hline Total autumn runoff & 30 & 24 & 24.3 & - & 22 & 22 & -1.5 \\
\hline Total winter runoff & 96 & 99 & -2.8 & - & 116 & 110 & 5.4 \\
\hline \multicolumn{8}{|c|}{$\begin{array}{l}03191500 \text { Peters Creek near Lockwood (LOCKWOOD) } \\
\text { Calibration period: October 1, 1945, to September 30, 1955; coefficient of determination is } 0.723 \\
\text { Verification period: October 1, 1955, to November 9,1971; coefficient of determination is } 0.647\end{array}$} \\
\hline Total runoff & 211 & 214 & -1.2 & 10 & 319 & 332 & -4.1 \\
\hline Total stormflow runoff & 107 & 106 & .5 & 15 & 169 & 175 & -3.2 \\
\hline Total base-flow runoff & 17 & 14 & 20.4 & - & 25 & 24 & 4.6 \\
\hline Total spring runoff & 74 & 80 & -7.3 & -- & 126 & 138 & -8.4 \\
\hline Total summer runoff & 32 & 29 & 9.2 & -- & 37 & 40 & -5.2 \\
\hline Total autumn runoff & 16 & 19 & -15.1 & - & 22 & 30 & -27.4 \\
\hline Total winter runoff & 89 & 86 & 3.7 & -- & 133 & 125 & 6.6 \\
\hline \multicolumn{8}{|c|}{$\begin{array}{c}03051500 \text { Middle Fork at Midvale (MIDVALE) } \\
\text { Calibration period: May 1, 1915, to April 30, 1933; coefficient of determination is } 0.546 \\
\text { Verification period: May 1, 1933, to September 30, 1942; coefficient of determination is } 0.530\end{array}$} \\
\hline Total runoff & 581 & 569 & 2.2 & 10 & 288 & 272 & 5.6 \\
\hline Total stormflow runoff & 261 & 254 & 2.8 & 15 & 138 & 126 & 9.5 \\
\hline Total base-flow runoff & 57 & 61 & -7.0 & - & 26 & 28 & -5.8 \\
\hline Total spring runoff & 203 & 211 & -4.0 & - & 105 & 110 & -4.6 \\
\hline Total summer runoff & 75 & 67 & 11.3 & - & 55 & 43 & 27.5 \\
\hline Total autumn runoff & 54 & 71 & -23.2 & -- & 20 & 26 & -21.1 \\
\hline Total winter runoff & 249 & 220 & 13.4 & - - & 107 & 93 & 14.9 \\
\hline
\end{tabular}




\section{Calibration Parameters}

The calibration parameters were determined by successive adjustment of an estimated 30 to 40 calibration cycles for each site. The calibration cycles included (1) simulation HSPF computer runs, (2) examination of daily and monthly hydrographs, (3) examination of seasonal characteristics of these hydrographs, (4) statistical comparisons, and (5) automated advice from HSPEXP. All parameters calculated from BASINS were retained, except for modification of time-series factors applied to precipitation and evaporation, addition of snow calculations, calibration of the PERLND parameters, and modification of IMPLND/ PERLND fractions (for BUFFALO).

The HSPF subroutine that computes the water budget for a PERLND (section PWATER of the module PERLND) receives the important input watershed parameters in groups that also are called tables. The major parameters are in HSPF PWATER groups 1 through 4; these are presented in tables 7-10. Subroutine PWATER calculates the components of the water budget, primarily to predict the total runoff from a pervious area. All these parameters for all basins - by basin and by PERLND number- are presented in tables 7-10. The PERLND numbers are assigned by BASINS/WinHSPF by size, largest PERLND first (numbered as "101"). In all cases, the Hardwood forest land use/land cover was the largest and, therefore, was 101.

Not much confidence is given to parameters for conifer forest, shrubland, barren land, surface water, and wetland landuse/land-cover classifications, presented in tables 7-10 and summarized in table 11, because the total of these classifications did not exceed 3 percent for any of the basins simulated. More confidence is given to parameters for the urban/developed land use/land cover, even though no more than 2 percent of the basins contained this classification, because the parameters were those from BRANDYWINE (which was developed by the Chesapeake Bay Program coincident with simulations of large urban/developed areas). Major calibration parameters for land-use/land-cover classifications, where sufficient confidence provides for guidance of these parameters for simulating other basins in the coal-mining region of West Virginia, are summarized in table 11 .

The characteristics of some model parameters for the primary PERLND, hardwood forest, including relative sensitivity in some cases, are discussed below. Sensitivity of parameters was not quantitatively analyzed in the streamflow simulations, but model calibration provides impressions of the relative sensitivity of some parameters.

FOREST. - The value of FOREST (parameter indicating the fraction of the land segment covered by forest transpiring in winter) was set to zero in most cases because other values result in simulations of winter streamflows that were too low (table 8).

LZSN.- The calibrations were relatively insensitive to LZSN (parameter for the nominal capacity of the lower zone storage). Frequently, the automated advice of HSPEXP was to revise LZSN, but following this advice before adjusting other parameters led to oddly high 25 -in. values or oddly low 0.1 -in. values without really solving water-balance problems. Therefore, a LZSN value similar to that of BRANDYWINE was selected, and LZSN was adjusted after all other HSPEXP advice had been followed. Calibrations were obtained using the value of LZSN for BRANDYWINE, 5.0 in., for five basins; the other three basins did not exceed $5.0 \mathrm{in}$. for the major PERLND (table 8).

INFILT. - The calibrations were fairly sensitive to INFILT (parameter for an index to the infiltration capacity of the soil). The values of INFILT for the major PERLND were inversely related to rainfall intensity at LOCKWOOD and MIDVALE (table 5). Five basins had values of INFILT between the Phase 3 and Phase 4.3 values for BRANDYWINE (0.04050 and $0.030000 \mathrm{in} / \mathrm{d}$, respectively). The value of INFILT for BUFFALO, $0.029 \mathrm{in} / \mathrm{d}$, is not far below the values for BRANDYWINE, but MIDVALE and VAUGHAN required 2 and 3 times the values for BRANDYWINE, respectively (table 8). VAUGHAN was so generally disturbed by mining that the value of INFILT was increased on the unmined forest PERLND. The high value of INFILT for MIDVALE was unexpected and is unexplained.

LSUR. - The calibrations are relatively insensitive to LSUR (parameter for the length of the overland flow plane). PANTHER had a value for LSUR of $300 \mathrm{ft}$ for the major PERLND, CLEAR FORK (and BRANDYWINE) had a value of $200 \mathrm{ft}$, and four of the remaining study basins had values of $100 \mathrm{ft}$ (table 8). The two extremes for LSUR were DUNLOW at $800 \mathrm{ft}$ and BUFFALO at $10 \mathrm{ft}$. DUNLOW (during an unmined period) and PANTHER, the two nearly pristine southernmost basins, had the two highest values for LSUR. BUFFALO is unlike the other basins because of high land disturbance from a century of mining, two centuries of logging, and three centuries of development. The low value for LSUR at BUFFALO may result partially because the SLSUR (parameter for the slope of the overland flow plane) value for BUFFALO was the lowest of the study.

SLSUR. - The value of SLSUR (parameter for the slope of the overland flow plane) calculated by BASINS was used. The lowest value for the major PERLND was $0.2368 \mathrm{ft} / \mathrm{ft}$ at BUFFALO (table 8). The value for the major PERLND at BUFFALO was much lower than the other seven study basins and even lower than BRANDYWINE at $0.2800 \mathrm{ft} / \mathrm{ft}$.

$K V A R Y$. - The calibrations were fairly sensitive to KVARY (parameter for indicating the behavior of the groundwater recession flow, enabling a non-exponential decay with time). A value of KVARY for the major PERLND ranging from 1.0 to 4.7 in. ${ }^{-1}$ was required for seven basins to adequately simulate the shape of the recessions (table 8). A value of KVARY equal to zero was required for VAUGHAN, the most heavily surface-mined basin. A value of KVARY equal to zero is unusual in this study, although normally expected elsewhere. A value of KVARY equal to zero is believed to occur only when disturbances in a basin result in ground water 
draining much more quickly than in an undisturbed basin. KVARY and AGWRC (parameter for the basic ground-water recession rate) tended to increase and decrease together, with the exception of values for VAUGHAN.

$A G W R C$. - The calibrations were fairly sensitive to AGWRC (parameter for the basic ground-water recession rate). Values for AGWRC ranged from 0.910 to $0.980 \mathrm{~d}^{-1}$ and were less than that for BRANDYWINE, $0.982 \mathrm{~d}^{-1}$, for all basins for the major PERLND (table 8). The two lowest values were for MIDVALE, $0.910 \mathrm{~d}^{-1}$, and VAUGHAN, 0.935 $\mathrm{d}^{-1}$. The low value at MIDVALE is coincident with the highest elevation of the study basins (table 3), but the reason for this low value is not fully understood. The low value at VAUGHN indicates that the active ground-water reservoir drains out quickly from the basin with the most disturbances because of mining. AGWRC and KVARY tended to increase and decrease together, with the exception of values for VAUGHAN.

PETMAX. - PETMAX is a parameter that indicates the air temperature below which evapotranspiration will be reduced if snow is simulated. A default value of $40^{\circ} \mathrm{F}$ was used except at MIDVALE where a value of $45^{\circ} \mathrm{F}$ helped reduce winter evaporation (table 9).

PETMIN. - PETMIN is a parameter that indicates the air temperature below which evapotranspiration will be forced to zero if snow is simulated. A default value of $35^{\circ} \mathrm{F}$ was used except at MIDVALE where a value of $42^{\circ} \mathrm{F}$ helped reduce winter evaporation (table 9).

INFEXP. - A default value of 2 for INFEXP (parameter for the exponent in the infiltration equation, dimensionless) was used (table 9).

INFILD. - A default value of 2 for INFILD (parameter for the ratio between the maximum and mean infiltration capacities over the land segment, dimensionless) was used (table 9).

DEEPFR. - The calibrations were so sensitive to DEEPFR (parameter for the fraction of ground-water inflow that flows to inactive ground water, dimensionless) that a constant year-round value of zero could not be used for all basins, so the value was specified seasonally (table 4). A special action of varying DEEPFR to a value greater than zero in the autumn for mined basins BUFFALO and VAUGHAN but also for the unmined period of DUNLOW was used for calibration. DEEPFR was greater than zero in the winter at VAUGHAN, the most heavily disturbed basin.

BASETP. - A value of zero for BASETP (parameter for the fraction of the remaining potential evapotranspiration that can be satisfied from base flow, dimensionless) was used except at DUNLOW, LOCKWOOD, and VAUGHAN, where a modest value of 0.005 was used to reduce simulated summer streamflows (table 9).

AGWETP.— A default value of zero for AGWETP (parameter for the fraction of remaining potential evapotranspiration that can be satisfied from active ground-water storage, dimensionless) was used (table 9).

CEPSC.- The calibrations were so sensitive to CEPSC (parameter for interception storage capacity) that lower values than those for BRANDYWINE generally had to be used for the major PERLND. This parameter was specified monthly for the eight study basins and BRANDYWINE (table 4). The average of the annual average of monthly values of CEPSC for the eight study basins was less than one-half the annual average of monthly values for BRANDYWINE of 0.108 in. These generally lower values of CEPSC had the advantage that small streamflow rises remained in the simulation, giving a full appearance to the hydrograph. The highest monthly value for CEPSC was 0.110 in. during the summer or autumn. The monthly values of CEPSC for the major PERLND ranged from 0.00 to $0.11 \mathrm{in}$. for the eight study basins compared to the monthly range of 0.01 to 0.16 in. for BRANDYWINE. The monthly value of CEPSC decreased to zero at least once for the eight study basins between February and April, whereas BRANDYWINE (in a more usual fashion) decreased to only 0.10 between November and March. The value of CEPSC for the eight study basins exceeded the value for BRANDYWINE only in late autumn, probably to account for fresh leaf litter or for the seasonal movement of the water table and transpiration of trees that necessitated the use of special action to vary DEEPFR.

UZSN.- The calibrations were fairly sensitive to UZSN (parameter for the nominal capacity of the upper zone storage). The values of UZSN for the major PERLND were specified monthly for the eight study basins (table 4) compared to BRANDYWINE where a constant value of $0.800 \mathrm{in}$. was used (table 10). The average of annual average of monthly values of UZSN for the eight study basins was 0.622 in., which was a little less than but comparable to the value for BRANDYWINE, 0.800 in. The maximum monthly value of UZSN was $2.50 \mathrm{in}$. for BUFFALO between September and December. The minimum monthly value of UZSN was $0.01 \mathrm{in}$. for all study basins, much lower than the value for BRANDYWINE. Generally, maximum values prevailed between September and December at five of the study basins probably to account for fresh leaf litter or because of the seasonal movement of the water table and transpiration of trees (that necessitated the use of special action to vary DEEPFR). Maximum values were less likely to occur between September and December at the three southernmost basins, PANTHER, DUNLOW, and CLEAR FORK, and the maximum monthly values of UZSN did not exceed 1.00. The maximum monthly value did not exceed $0.20 \mathrm{in}$. at PANTHER.

The value of UZSN was positively correlated to the latitude of the basin location (fig. 5). The correlation between values of UZSN and latitude could be because of decreasing slopes, decreasing rockiness of the soils, and increasing soil depths from south to north.

NSUR.- The calibrations are relatively insensitive to NSUR (parameter for Manning's roughness of the land surface). The values of NSUR for the major PERLND were constant for all basins (table 9) except for DUNLOW, where the values were specified monthly (table 4). The values for DUNLOW were specified as 0.10 (dimensionless) for the winter months to increase streamflow peaks, were specified 
as 0.80 for the summer months to decrease streamflow peaks, and were varied between 0.10 and 0.80 for months during the spring and autumn.

INTFW. - The calibrations were fairly sensitive to INTFW (parameter for the interflow inflow). The values of INTFW for the major PERLND ranged from 0.68 to 3.40 (dimensionless) for the study basins compared to the value for BRANDYWINE of 1.70 (table 10). INTFW was applied as a constant for each basin, but it could have been specified monthly. Monthly specification was not incorporated for calibration because it was not essential and is rarely used. INTFW was modified when advised by HSPEXP and also was increased to broaden streamflow rises on the hydrograph.

$I R C$. - The calibrations were quite sensitive to IRC (parameter for the interflow recession constant, ratio of a given day's interflow to the previous day's). Values of IRC for the major PERLND ranged from 0.065 to $0.390 \mathrm{~d}^{-1}$ for the eight study basins and were lower on average than the value for BRANDYWINE of $0.650 \mathrm{~d}^{-1}$ (table 10). IRC was modified when advised by HSPEXP and also decreased when it was found necessary to fit the lower half of the hydrograph.
LZETP. - The calibrations were fairly sensitive to LZETP (parameter for the lower-zone evapotranspiration), which was specified monthly for the eight study basins (table 4). The annual average of monthly values of LZETP for the study basins ranged from 0.289 to 0.403 (dimensionless), close to the constant value at BRANDYWINE of 0.400 (table 10). The minimum monthly value of LZETP was 0.01 , an unusually low value, for most basins between about December and May, except for AUDRA and BUFFALO. AUDRA and BUFFALO are the two northernmost basins, and the value of 0.01 was applied only between about February and May. The unusually low value of LZETP was necessary to achieve adequate winter streamflow. The maximum monthly values of LZETP ranged from 0.55 to 0.99. LZETP was a conventional value of 0.55 for AUDRA and BUFFALO, the two northernmost basins; a relatively high value of 0.90 for LOCKWOOD, MIDVALE, and VAUGHAN; and a very high value of 0.99 for PANTHER, DUNLOW, and CLEAR FORK, the three southernmost basins. Values of LZETP greater than 0.99 are impossible within the concepts of the HSPF model and are not permitted by it, but they would have provided a better estimate of streamflow.

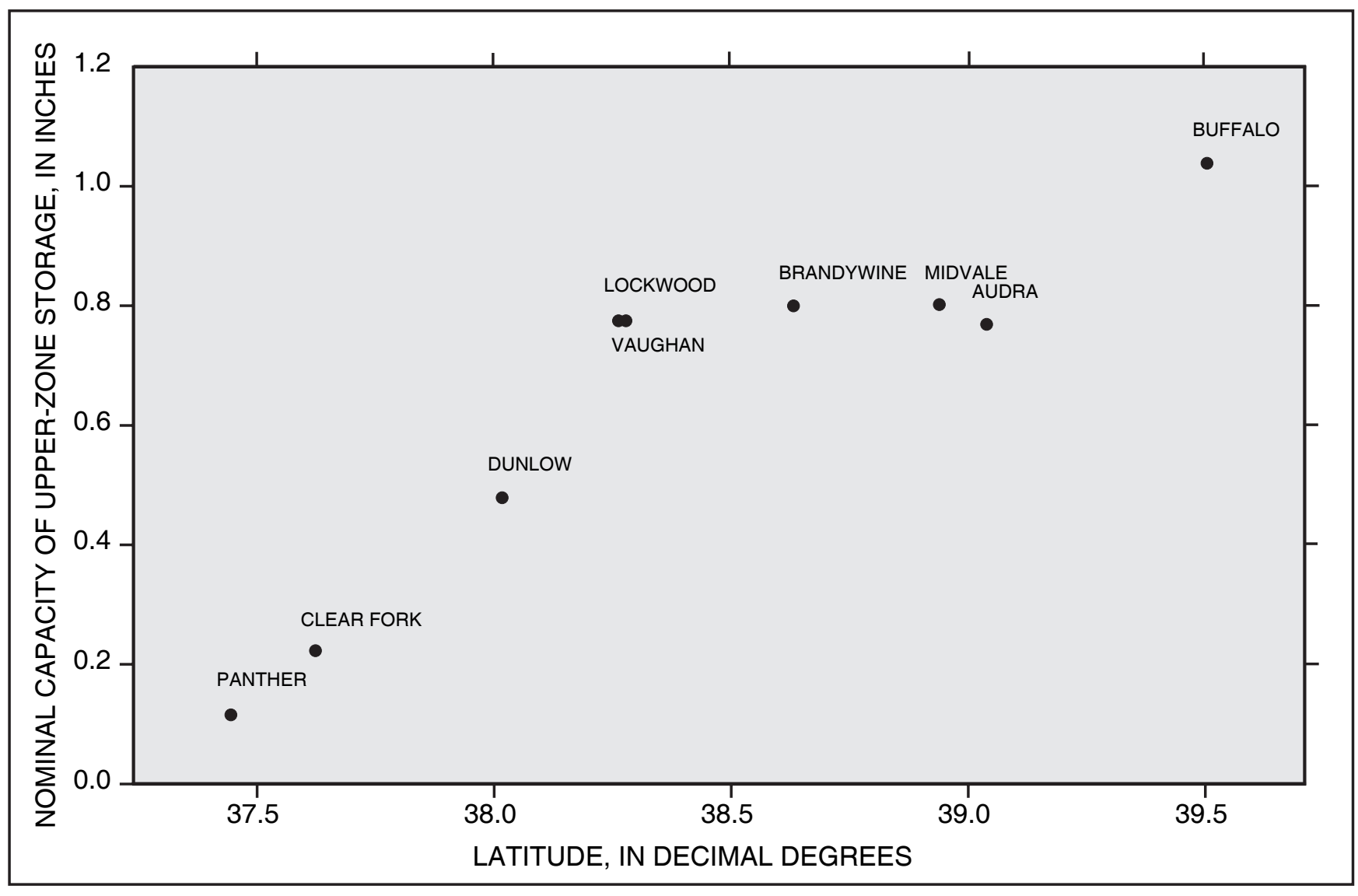

Figure 5. Relation among the average monthly values of the nominal moisture capacity of the upper soil zone (UZSN) for the eight study basins and the Brandywine Basin in West Virginia and Virginia. 
Table 7. Hydrologic Simulation Program-FORTRAN Model (HSPF) parameters for simulation of pervious land segments (PERLNDs), group 1 of subroutine named "PWATER," including the Brandywine Basin in West Virginia and Virginia, used in this study.

[CSNOFG is 1 if snow accumulation and melt are being considered; RTOPFG is 1 if routing of overland flow as in predecessor models; UZFG is 1 if upper-zone inflow is computed as in predecessor models; VCSFG is 1 if interception storage capacity can vary monthly; VUZFG is 1 if upper-zone nominal storage can vary monthly; VNNFG is 1 if Manning's roughness for the overland flow plane can vary monthly; VIFWFG is 1 if interflow inflow parameter can vary monthly and 0 if constant; VIRCFG is 1 if interflow recession constant can vary monthly and 0 if constant; VLEFG is 1 if lower-zone evapotranspiration parameter can vary monthly and 0 if constant; IFFCFG is 1 if effect of frozen ground on infiltration rate is calculated, 0 if not, and "-“ if IFFCG does not apply]

\begin{tabular}{|c|c|c|c|c|c|c|c|c|c|c|c|}
\hline \multirow{7}{*}{$\begin{array}{l}\text { PERLND } \\
\text { number }\end{array}$} & \multirow{7}{*}{ Land use/land cover } & C & $\mathbf{R}$ & & & & & $\mathbf{v}$ & $\mathbf{v}$ & & \\
\hline & & $\mathbf{S}$ & $\mathbf{T}$ & & V & V & $\mathbf{V}$ & I & I & V & I \\
\hline & & $\mathbf{N}$ & $\mathbf{0}$ & $\mathbf{U}$ & C & U & $\mathbf{N}$ & $\mathbf{R}$ & $\mathbf{R}$ & $\mathbf{L}$ & $\mathbf{F}$ \\
\hline & & 0 & $\mathbf{P}$ & $\mathbf{Z}$ & $\mathbf{S}$ & Z & $\mathbf{N}$ & $\mathbf{w}$ & C & $\mathbf{E}$ & C \\
\hline & & $\mathbf{F}$ & $\mathbf{F}$ & $\mathbf{F}$ & $\mathbf{F}$ & $\mathbf{F}$ & $\mathbf{F}$ & $\mathbf{F}$ & $\mathbf{F}$ & $\mathbf{F}$ & $\mathbf{F}$ \\
\hline & & G & G & G & G & G & G & G & G & G & $\mathbf{G}$ \\
\hline & & \multicolumn{10}{|c|}{ All parameters are dimensionless } \\
\hline \multicolumn{12}{|c|}{01607500 South Fork South Branch Potomac River at Brandywine (BRANDYWINE) } \\
\hline 171 & Forest & 1 & 1 & 1 & 1 & 0 & 0 & 0 & 0 & 0 & - \\
\hline 172 & High till cropland & 1 & 1 & 1 & 1 & 1 & 1 & 0 & 0 & 1 & - \\
\hline 173 & Low till cropland & 1 & 1 & 1 & 1 & 1 & 1 & 0 & 0 & 1 & - \\
\hline 174 & Pasture & 1 & 1 & 1 & 1 & 0 & 0 & 0 & 0 & 0 & - \\
\hline 175 & Urban & 1 & 1 & 1 & 1 & 0 & 0 & 0 & 0 & 0 & - \\
\hline 176 & Hay & 1 & 1 & 1 & 1 & 0 & 0 & 0 & 0 & 0 & - \\
\hline \multicolumn{12}{|c|}{03052000 Middle Fork River at Audra (AUDRA) } \\
\hline 101 & Hardwood forest & 1 & 1 & 1 & 1 & 1 & 0 & 0 & 0 & 1 & 1 \\
\hline 102 & Shrubland & 1 & 1 & 1 & 1 & 1 & 0 & 0 & 0 & 1 & 1 \\
\hline 103 & Pasture / grassland & 1 & 1 & 1 & 1 & 1 & 0 & 0 & 0 & 1 & 1 \\
\hline 104 & Row crop agriculture & 1 & 1 & 1 & 1 & 1 & 0 & 0 & 0 & 1 & 1 \\
\hline 105 & Urban / developed & 1 & 1 & 1 & 1 & 1 & 0 & 0 & 0 & 1 & 1 \\
\hline 106 & Barren land & 1 & 1 & 1 & 1 & 1 & 0 & 0 & 0 & 1 & 1 \\
\hline 107 & Wetland & 1 & 1 & 1 & 1 & 0 & 0 & 0 & 0 & 1 & 1 \\
\hline 108 & Mined land & 1 & 1 & 1 & 1 & 0 & 0 & 0 & 0 & 1 & 1 \\
\hline 109 & Surface water & 1 & 1 & 1 & 1 & 0 & 0 & 0 & 0 & 1 & 1 \\
\hline 110 & Conifer forest & 1 & 1 & 1 & 1 & 0 & 0 & 0 & 0 & 1 & 1 \\
\hline \multicolumn{12}{|c|}{03061500 Buffalo Creek at Barrackville (BUFFALO) } \\
\hline 101 & Hardwood forest & 1 & 1 & 1 & 1 & 1 & 0 & 0 & 0 & 1 & 1 \\
\hline 102 & Shrubland & 1 & 1 & 1 & 1 & 1 & 0 & 0 & 0 & 1 & 1 \\
\hline 103 & Pasture / grassland & 1 & 1 & 1 & 1 & 1 & 0 & 0 & 0 & 1 & 1 \\
\hline 104 & Urban / developed & 1 & 1 & 1 & 1 & 1 & 0 & 0 & 0 & 1 & 1 \\
\hline 105 & Barren land & 1 & 1 & 1 & 1 & 1 & 0 & 0 & 0 & 1 & 1 \\
\hline 106 & Wetland & 1 & 1 & 1 & 1 & 1 & 0 & 0 & 0 & 1 & 1 \\
\hline 107 & Surface water & 1 & 1 & 1 & 1 & 1 & 0 & 0 & 0 & 1 & 1 \\
\hline 108 & Mined land & 1 & 1 & 1 & 1 & 1 & 0 & 0 & 0 & 1 & 1 \\
\hline
\end{tabular}


Table 7. Hydrologic Simulation Program-FORTRAN Model (HSPF) parameters for simulation of pervious land segments (PERLNDs), group 1 of subroutine named "PWATER," including the Brandywine Basin in West Virginia and Virginia, used in this study.-Continued

[CSNOFG is 1 if snow accumulation and melt are being considered; RTOPFG is 1 if routing of overland flow as in predecessor models; UZFG is 1 if upper-zone inflow is computed as in predecessor models; VCSFG is 1 if interception storage capacity can vary monthly; VUZFG is 1 if upper-zone nominal storage can vary monthly; VNNFG is 1 if Manning's roughness for the overland flow plane can vary monthly; VIFWFG is 1 if interflow inflow parameter can vary monthly and 0 if constant; VIRCFG is 1 if interflow recession constant can vary monthly and 0 if constant; VLEFG is 1 if lower-zone evapotranspiration parameter can vary monthly and 0 if constant; IFFCFG is 1 if effect of frozen ground on infiltration rate is calculated, 0 if not, and "-" if IFFCG does not apply]

\begin{tabular}{|c|c|c|c|c|c|c|c|c|c|c|c|c|}
\hline \multirow{7}{*}{$\begin{array}{l}\text { PERLND } \\
\text { number }\end{array}$} & \multirow{7}{*}{\multicolumn{2}{|c|}{ Land use/land cover }} & C & \multicolumn{5}{|l|}{$\mathbf{R}$} & \multicolumn{4}{|c|}{$\begin{array}{ll}\mathbf{V} & \mathbf{V}\end{array}$} \\
\hline & & & $\mathbf{S}$ & $\mathbf{T}$ & & $\mathbf{v}$ & $\mathbf{V}$ & $\mathbf{v}$ & I & $\mathbf{I}$ & $\mathbf{v}$ & I \\
\hline & & & $\mathbf{N}$ & 0 & $\mathbf{U}$ & C & $\mathbf{U}$ & $\mathbf{N}$ & $\mathbf{R}$ & $\mathbf{R}$ & $\mathbf{L}$ & $\mathbf{F}$ \\
\hline & & & 0 & $\mathbf{P}$ & Z & $\mathbf{S}$ & Z & $\mathbf{N}$ & W & C & $E$ & C \\
\hline & & & $\mathbf{F}$ & $\mathbf{F}$ & $\mathbf{F}$ & $\mathbf{F}$ & $\mathbf{F}$ & $\mathbf{F}$ & $\mathbf{F}$ & $\mathbf{F}$ & $\mathbf{F}$ & $\mathbf{F}$ \\
\hline & & & G & G & G & G & G & G & G & G & G & G \\
\hline & & & \multicolumn{10}{|c|}{ All parameters are dimensionless } \\
\hline \multicolumn{13}{|c|}{03202750 Clear Fork at Clear Fork (CLEAR FORK) } \\
\hline 101 & Hardwood forest & & 1 & 1 & 1 & 1 & 1 & 0 & 0 & 0 & 1 & 1 \\
\hline 102 & Shrubland & & 1 & 1 & 1 & 1 & 1 & 0 & 0 & 0 & 1 & 1 \\
\hline 103 & Row crop agriculture & & 1 & 1 & 1 & 1 & 1 & 0 & 0 & 0 & 1 & 1 \\
\hline 104 & Barren land & & 1 & 1 & 1 & 1 & 1 & 0 & 0 & 0 & 1 & 1 \\
\hline 105 & Wetland & & 1 & 1 & 1 & 1 & 0 & 0 & 0 & 0 & 1 & 1 \\
\hline 106 & Surface water & & 1 & 1 & 1 & 1 & 0 & 0 & 0 & 0 & 1 & 1 \\
\hline 107 & Mined land & & 1 & 1 & 1 & 1 & 0 & 0 & 0 & 0 & 1 & 1 \\
\hline 108 & Pasture / grassland & & 1 & 1 & 1 & 1 & 0 & 0 & 0 & 0 & 1 & 1 \\
\hline 109 & Urban / developed & & 1 & 1 & 1 & 0 & 0 & 0 & 0 & 0 & 1 & 1 \\
\hline 101 & Hardwood forest & & 1 & 1 & 1 & 1 & 1 & 0 & 0 & 0 & 1 & 1 \\
\hline \multicolumn{13}{|c|}{03206600 East Fork Twelvepole Creek near Dunlow (DUNLOW) } \\
\hline 101 & Hardwood forest & & 1 & 1 & 1 & 1 & 1 & 1 & 0 & 0 & 1 & 1 \\
\hline 102 & Barren land & & 1 & 1 & 1 & 1 & 1 & 0 & 0 & 0 & 1 & 1 \\
\hline 103 & Mined land & & 1 & 1 & 1 & 1 & 1 & 0 & 0 & 0 & 1 & 1 \\
\hline 104 & Shrubland & & 1 & 1 & 1 & 1 & 1 & 0 & 0 & 0 & 1 & 1 \\
\hline 105 & Pasture / grassland & & 1 & 1 & 1 & 1 & 1 & 0 & 0 & 0 & 1 & 1 \\
\hline 106 & Urban / developed & & 1 & 1 & 1 & 1 & 1 & 0 & 0 & 0 & 1 & 1 \\
\hline 107 & Surface water & & 1 & 1 & 1 & 1 & 1 & 0 & 0 & 0 & 1 & 1 \\
\hline 108 & Row crop agriculture & & 1 & 1 & 1 & 1 & 1 & 1 & 0 & 0 & 1 & 1 \\
\hline \multicolumn{13}{|c|}{03191500 Peters Creek near Lockwood (LOCKWOOD) } \\
\hline 101 & Hardwood forest & & 1 & 1 & 1 & 1 & 1 & 0 & 0 & 0 & 1 & 1 \\
\hline 102 & Pasture / grassland & & 1 & 1 & 1 & 1 & 1 & 0 & 0 & 0 & 1 & 1 \\
\hline 103 & Urban / developed & & 1 & 1 & 1 & 1 & 1 & 0 & 0 & 0 & 1 & 1 \\
\hline 104 & Barren land & & 1 & 1 & 1 & 1 & 1 & 0 & 0 & 0 & 1 & 1 \\
\hline 105 & Mined land & & 1 & 1 & 1 & 1 & 1 & 0 & 0 & 0 & 1 & 1 \\
\hline 106 & Row crop agriculture & & 1 & 1 & 1 & 1 & 1 & 0 & 0 & 0 & 1 & 1 \\
\hline 107 & Wetland & & 1 & 1 & 1 & 1 & 1 & 0 & 0 & 0 & 1 & 1 \\
\hline 108 & Shrubland & & 1 & 1 & 1 & 1 & 1 & 0 & 0 & 0 & 1 & 1 \\
\hline 109 & Surface water & & 1 & 1 & 1 & 1 & 1 & 0 & 0 & 0 & 1 & 1 \\
\hline
\end{tabular}


Table 7. Hydrologic Simulation Program-FORTRAN Model (HSPF) parameters for simulation of pervious land segments (PERLNDs), group 1 of subroutine named "PWATER," including the Brandywine Basin in West Virginia and Virginia, used in this study.-Continued

[CSNOFG is 1 if snow accumulation and melt are being considered; RTOPFG is 1 if routing of overland flow as in predecessor models; UZFG is 1 if upper-zone inflow is computed as in predecessor models; VCSFG is 1 if interception storage capacity can vary monthly; VUZFG is 1 if upper-zone nominal storage can vary monthly; VNNFG is 1 if Manning's roughness for the overland flow plane can vary monthly; VIFWFG is 1 if interflow inflow parameter can vary monthly and 0 if constant; VIRCFG is 1 if interflow recession constant can vary monthly and 0 if constant; VLEFG is 1 if lower-zone evapotranspiration parameter can vary monthly and 0 if constant; IFFCFG is 1 if effect of frozen ground on infiltration rate is calculated, 0 if not, and "- " if IFFCG does not apply]

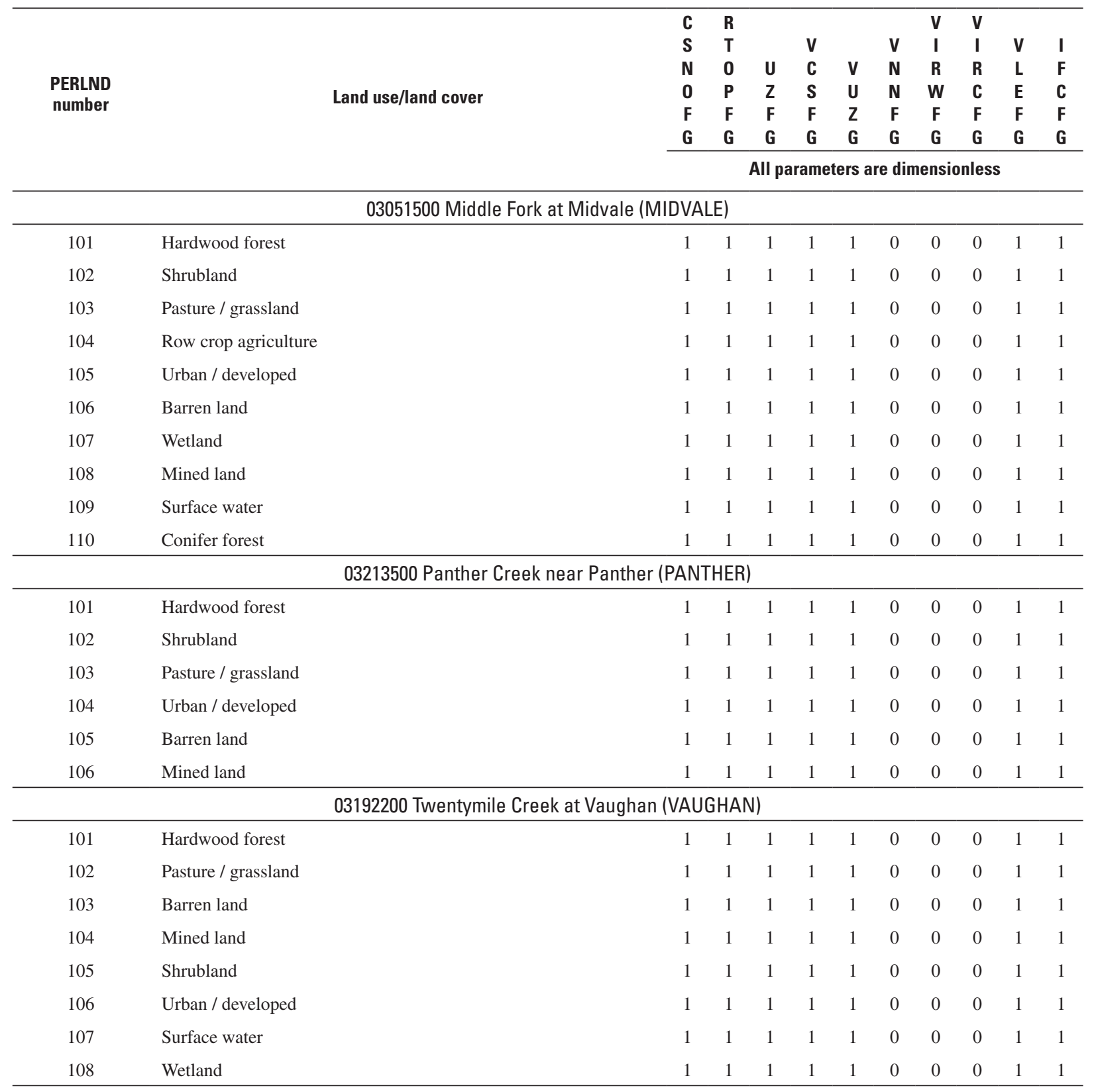


Table 8. Hydrologic Simulation Program-FORTRAN Model (HSPF) parameters for simulation of pervious land segments (PERLNDs), group 2 of subroutine named "PWATER," including the Brandywine Basin in West Virginia and Virginia, used in this study.

[FOREST, fraction of the pervious land segment covered by forest transpiring in winter; LZSN, nominal storage of the lower soil zone; INFILT, index to the infiltration capacity of the soil; LSUR, the length of the assumed overland flow plane; SLSUR, slope of the overland flow plane; KVARY, controls the behavior of ground-water recession flow, enabling a non-exponential decay with time; AGWRC, basic ground-water recession rate]

\begin{tabular}{|c|c|c|c|c|c|c|c|c|}
\hline $\begin{array}{l}\text { PERLND } \\
\text { number }\end{array}$ & $\begin{array}{l}\text { Land use/ } \\
\text { land cover }\end{array}$ & $\begin{array}{c}\text { FOREST, } \\
\text { dimension- } \\
\text { less }\end{array}$ & $\begin{array}{l}\text { LZSN, in } \\
\text { inches }\end{array}$ & $\begin{array}{c}\text { INFILT, in } \\
\text { inches per } \\
\text { day }\end{array}$ & $\begin{array}{l}\text { LSUR, in } \\
\text { feet }\end{array}$ & $\begin{array}{l}\text { SLSUR, in } \\
\text { foot per foot }\end{array}$ & $\begin{array}{l}\text { KVARY, in } \\
\text { inches }^{-1}\end{array}$ & $\begin{array}{l}\text { AGWRC, in } \\
\text { day }^{-1}\end{array}$ \\
\hline \multicolumn{9}{|c|}{01607500 South Fork South Branch Potomac River at Brandywine (BRANDYWINE) } \\
\hline 171 & Forest & 0.0 & 5.0 & 0.04050 & 200 & 0.2800 & 0.0 & 0.982 \\
\hline 172 & High till cropland & .0 & 5.0 & .03400 & 300 & .0800 & .0 & .982 \\
\hline 173 & Low till cropland & .0 & 5.0 & .03400 & 300 & .0800 & .0 & .982 \\
\hline 174 & Pasture & .0 & 5.0 & .03000 & 250 & .1500 & .0 & .982 \\
\hline 175 & Urban & .0 & 5.0 & .03000 & 300 & .0800 & .0 & .982 \\
\hline 176 & Hay & .0 & 5.0 & .03000 & 250 & .1500 & .0 & .982 \\
\hline \multicolumn{9}{|c|}{03052000 Middle Fork River at Audra (AUDRA) } \\
\hline 101 & Hardwood forest & 0.0 & 5.0 & 0.04050 & 100 & 0.4389 & 4.5 & 0.980 \\
\hline 102 & Shrubland & .0 & 5.0 & .04050 & 100 & .4389 & 4.5 & .980 \\
\hline 103 & Pasture / grassland & .0 & 5.0 & .03000 & 125 & .4389 & 4.5 & .980 \\
\hline 104 & Row crop agriculture & .0 & 5.0 & .03400 & 150 & .4389 & 4.5 & .980 \\
\hline 105 & Urban / developed & .0 & 5.0 & .03000 & 150 & .4389 & 4.5 & .980 \\
\hline 106 & Barren land & .0 & 5.0 & .04050 & 100 & .4389 & 4.5 & .980 \\
\hline 107 & Wetland & .0 & 5.0 & .16000 & 150 & .4389 & 4.5 & .980 \\
\hline 108 & Mined land & .0 & 5.0 & .16000 & 150 & .4389 & 4.5 & .980 \\
\hline 109 & Surface water & .0 & 5.0 & .16000 & 150 & .3691 & 4.5 & .980 \\
\hline 110 & Conifer forest & .0 & 5.0 & .04050 & 100 & .4008 & 4.5 & .980 \\
\hline \multicolumn{9}{|c|}{03061500 Buffalo Creek at Barrackville (BUFFALO) } \\
\hline 101 & Hardwood forest & 0.3 & 5.0 & 0.02900 & 10 & 0.2368 & 4.5 & 0.970 \\
\hline 102 & Shrubland & .3 & 5.0 & .02900 & 10 & .2368 & 4.5 & .970 \\
\hline 103 & Pasture / grassland & .3 & 5.0 & .03000 & 10 & .2368 & 4.5 & .970 \\
\hline 104 & Urban / developed & .3 & 5.0 & .00200 & 10 & .2368 & 4.5 & .970 \\
\hline 105 & Barren land & .3 & 5.0 & .02900 & 10 & .2368 & 4.5 & .970 \\
\hline 106 & Wetland & .3 & 1.0 & .16000 & 1 & .2368 & 4.5 & .970 \\
\hline 107 & Surface water & .0 & 0.1 & .16000 & 1 & .2368 & 4.5 & .970 \\
\hline 108 & Mined land & .0 & 2.0 & .50000 & 75 & .2340 & 4.5 & .970 \\
\hline
\end{tabular}


Table 8. Hydrologic Simulation Program-FORTRAN Model (HSPF) parameters for simulation of pervious land segments (PERLNDs), group 2 of subroutine named "PWATER," including the Brandywine Basin in West Virginia and Virginia, used in this study.Continued

[FOREST, fraction of the pervious land segment covered by forest transpiring in winter; LZSN, nominal storage of the lower soil zone; INFILT, index to the infiltration capacity of the soil; LSUR, the length of the assumed overland flow plane; SLSUR, slope of the overland flow plane; KVARY, controls the behavior of ground-water recession flow, enabling a non-exponential decay with time; AGWRC, basic ground-water recession rate]

\begin{tabular}{|c|c|c|c|c|c|c|c|c|}
\hline $\begin{array}{l}\text { PERLND } \\
\text { number }\end{array}$ & $\begin{array}{l}\text { Land use/ } \\
\text { land cover }\end{array}$ & $\begin{array}{c}\text { FOREST, } \\
\text { dimension- } \\
\text { less }\end{array}$ & $\begin{array}{l}\text { LZSN, in } \\
\text { inches }\end{array}$ & $\begin{array}{c}\text { INFILT, in } \\
\text { inches per } \\
\text { day }\end{array}$ & $\begin{array}{l}\text { LSUR, in } \\
\text { feet }\end{array}$ & $\begin{array}{l}\text { SLSUR, in } \\
\text { foot per foot }\end{array}$ & $\begin{array}{l}\text { KVARY, in } \\
\text { inches }^{-1}\end{array}$ & $\begin{array}{l}\text { AGWRC, in } \\
\text { day }^{-1}\end{array}$ \\
\hline \multicolumn{9}{|c|}{03202750 Clear Fork at Clear Fork (CLEAR FORK) } \\
\hline 101 & Hardwood forest & 0.1 & 3.0 & 0.03500 & 200 & 0.5689 & 2.5 & 0.970 \\
\hline 102 & Shrubland & .1 & 3.0 & .03500 & 200 & .3000 & 2.5 & .970 \\
\hline 103 & Row crop agriculture & .1 & 5.0 & .03400 & 300 & .5689 & 2.5 & .970 \\
\hline 104 & Barren land & .1 & 3.0 & .03500 & 200 & .5689 & 2.5 & .970 \\
\hline 105 & Wetland & .1 & 5.0 & .03000 & 50 & .3000 & 2.5 & .970 \\
\hline 106 & Surface water & .0 & 5.0 & .01000 & 5 & .5689 & 2.5 & .970 \\
\hline 107 & Mined land & .0 & 5.0 & .16000 & 100 & .5689 & 2.5 & .970 \\
\hline 108 & Pasture / grassland & .1 & 5.0 & .03000 & 250 & .5689 & 2.5 & .970 \\
\hline 109 & Urban / developed & .1 & 1.0 & .00100 & 50 & .0800 & 2.5 & .970 \\
\hline \multicolumn{9}{|c|}{03206600 East Fork Twelvepole Creek near Dunlow (DUNLOW) } \\
\hline 101 & Hardwood forest & 0.0 & 5.0 & 0.03000 & 800 & 0.3717 & 3.0 & 0.970 \\
\hline 102 & Barren land & .0 & 5.0 & .03000 & 500 & .3717 & 3.0 & .970 \\
\hline 103 & Mined land & .0 & 5.0 & .16000 & 400 & .4307 & 3.0 & .970 \\
\hline 104 & Shrubland & .0 & 5.0 & .03000 & 500 & .4307 & 3.0 & .970 \\
\hline 105 & Pasture / grassland & .0 & 5.0 & .03000 & 500 & .4307 & 3.0 & .970 \\
\hline 106 & Urban / developed & .0 & 5.0 & .03000 & 600 & .4307 & 3.0 & .970 \\
\hline 107 & Surface water & .0 & 5.0 & .16000 & 400 & .3642 & 3.0 & .970 \\
\hline 108 & Row crop agriculture & .0 & 5.0 & .03400 & 600 & .4073 & 3.0 & .970 \\
\hline \multicolumn{9}{|c|}{03191500 Peters Creek near Lockwood (LOCKWOOD) } \\
\hline 101 & Hardwood forest & 0.0 & 5.0 & 0.03000 & 100 & 0.4759 & 1.9 & 0.940 \\
\hline 102 & Pasture / grassland & .0 & 5.0 & .03000 & 125 & .4759 & 1.9 & .940 \\
\hline 103 & Urban / developed & .0 & 5.0 & .03000 & 150 & .4759 & 1.9 & .940 \\
\hline 104 & Barren land & .0 & 5.0 & .03000 & 100 & .4759 & 1.9 & .940 \\
\hline 105 & Mined land & .0 & 5.0 & .16000 & 150 & .4759 & 1.9 & .940 \\
\hline 106 & Row crop agriculture & .0 & 5.0 & .03400 & 150 & .3415 & 1.9 & .940 \\
\hline 107 & Wetland & .0 & 5.0 & .16000 & 150 & .3415 & 1.9 & .940 \\
\hline 108 & Shrubland & .0 & 5.0 & .03000 & 100 & .4164 & 1.9 & .940 \\
\hline 109 & Surface water & .0 & 5.0 & .16000 & 150 & .4164 & 1.9 & .940 \\
\hline
\end{tabular}




\section{$24 \quad$ HSPF Calibration Parameters for Mountainious, Mined Basins, West Virginia}

Table 8. Hydrologic Simulation Program-FORTRAN Model (HSPF) parameters for simulation of pervious land segments (PERLNDs), group 2 of subroutine named "PWATER," including the Brandywine Basin in West Virginia and Virginia, used in this study.Continued

[FOREST, fraction of the pervious land segment covered by forest transpiring in winter; LZSN, nominal storage of the lower soil zone; INFILT, index to the infiltration capacity of the soil; LSUR, the length of the assumed overland flow plane; SLSUR, slope of the overland flow plane; KVARY, controls the behavior of ground-water recession flow, enabling a non-exponential decay with time; AGWRC, basic ground-water recession rate]

\begin{tabular}{|c|c|c|c|c|c|c|c|c|}
\hline $\begin{array}{l}\text { PERLND } \\
\text { number }\end{array}$ & $\begin{array}{l}\text { Land use/ } \\
\text { land cover }\end{array}$ & $\begin{array}{c}\text { FOREST, } \\
\text { dimension- } \\
\text { less }\end{array}$ & $\begin{array}{l}\text { LZSN, in } \\
\text { inches }\end{array}$ & $\begin{array}{l}\text { INFILT, in } \\
\text { inches per } \\
\text { day }\end{array}$ & $\begin{array}{l}\text { LSUR, in } \\
\text { feet }\end{array}$ & $\begin{array}{l}\text { SLSUR, in } \\
\text { foot per foot }\end{array}$ & $\begin{array}{l}\text { KVARY, in } \\
\text { inches }^{-1}\end{array}$ & $\begin{array}{l}\text { AGWRC, in } \\
\text { day }^{-1}\end{array}$ \\
\hline \multicolumn{9}{|c|}{03051500 Middle Fork at Midvale (MIDVALE) } \\
\hline 101 & Hardwood forest & 0.0 & 1.5 & 0.08100 & 100 & 0.4389 & 1.0 & 0.910 \\
\hline 102 & Shrubland & .0 & 1.5 & .08100 & 100 & .4389 & 1.0 & .910 \\
\hline 103 & Pasture / grassland & .0 & 5.0 & .07500 & 125 & .4389 & 1.0 & .910 \\
\hline 104 & Row crop agriculture & .0 & 5.0 & .08500 & 150 & .4389 & 1.0 & .910 \\
\hline 105 & Urban / developed & .0 & 5.0 & .07500 & 150 & .4389 & 1.0 & .910 \\
\hline 106 & Barren land & .0 & 1.5 & .08100 & 100 & .4389 & 1.0 & .910 \\
\hline 107 & Wetland & .0 & 5.0 & .16000 & 150 & .4389 & 1.0 & .910 \\
\hline 108 & Mined land & .0 & 5.0 & .16000 & 150 & .4389 & 1.0 & .970 \\
\hline 109 & Surface water & .0 & 5.0 & .16000 & 150 & .3691 & 1.0 & .970 \\
\hline 110 & Conifer forest & .0 & 1.5 & .08100 & 100 & .3048 & 1.0 & .910 \\
\hline \multicolumn{9}{|c|}{03213500 Panther Creek near Panther (PANTHER) } \\
\hline 101 & Hardwood forest & 0.0 & 2.5 & 0.03037 & 300 & 0.5252 & 4.7 & 0.980 \\
\hline 102 & Shrubland & .0 & 5.0 & .03037 & 300 & .5252 & 4.7 & .980 \\
\hline 103 & Pasture / grassland & .0 & 5.0 & .01870 & 300 & .5252 & 4.7 & .980 \\
\hline 104 & Urban / developed & .0 & 5.0 & .80000 & 450 & .5252 & .0 & .990 \\
\hline 105 & Barren land & .0 & 5.0 & .03037 & 300 & .5252 & 4.7 & .980 \\
\hline 106 & Mined land & .0 & 5.0 & .90000 & 150 & .5252 & .0 & .990 \\
\hline \multicolumn{9}{|c|}{03192200 Twentymile Creek at Vaughan (VAUGHAN) } \\
\hline 101 & Hardwood forest & 0.0 & 5.0 & 0.12200 & 100 & 0.5414 & 0.0 & 0.935 \\
\hline 102 & Pasture / grassland & .0 & 5.0 & .09000 & 125 & .5414 & .0 & .935 \\
\hline 103 & Barren land & .0 & 5.0 & .12200 & 100 & .5414 & .0 & .935 \\
\hline 104 & Mined land & .4 & 10.0 & .95000 & 150 & .5414 & .0 & .935 \\
\hline 105 & Shrubland & .0 & 5.0 & .12200 & 100 & .5697 & .0 & .935 \\
\hline 106 & Urban / developed & .0 & 5.0 & .09000 & 150 & .5857 & .0 & .935 \\
\hline 107 & Surface water & 1.0 & 5.0 & .16000 & 150 & .6096 & .0 & .935 \\
\hline 108 & Wetland & 1.0 & 5.0 & .16000 & 150 & .6211 & .0 & .930 \\
\hline
\end{tabular}


Table 9. Hydrologic Simulation Program-FORTRAN Model (HSPF) parameters for simulation of pervious land segments (PERLNDs), group 3 of subroutine named "PWATER," including the Brandywine Basin in West Virginia and Virginia, used in this study.

[PETMAX, air temperature below which evapotranspiration will be reduced if snow is simulated; PETMIN, air temperature below which evapotranspiration will be forced to zero if snow is simulated; INFEXP, exponent in the infiltration equation; INFILD, ratio between the maximum and mean infiltration capacities over the land segment; DEEPFR, fraction of ground-water inflow that flows to inactive ground water (varies by special action for values greater than zero for this study); BASETP, fraction of remaining potential evapotranspiration that can be satisfied from base flow; AGWETP, fraction of remaining potential evapotranspiration that can be satisfied from active ground-water storage; shaded table cells are the annual average of monthly values]

\begin{tabular}{|c|c|c|c|c|c|c|c|c|}
\hline $\begin{array}{l}\text { PERLND } \\
\text { number }\end{array}$ & $\begin{array}{l}\text { Land use/ } \\
\text { land cover }\end{array}$ & $\begin{array}{c}\text { PETMAX, } \\
\text { in degrees } \\
\text { Fahrenheit }\end{array}$ & $\begin{array}{c}\text { PETMIN, } \\
\text { in degrees } \\
\text { Fahrenheit }\end{array}$ & $\begin{array}{c}\text { INFEXP, } \\
\text { dimension- } \\
\text { less }\end{array}$ & $\begin{array}{c}\text { INFILD, } \\
\text { dimension- } \\
\text { less }\end{array}$ & $\begin{array}{c}\text { DEEPFR, } \\
\text { dimension- } \\
\text { less }\end{array}$ & $\begin{array}{c}\text { BASETP, } \\
\text { dimension- } \\
\text { less }\end{array}$ & $\begin{array}{c}\text { AGWETP, } \\
\text { dimension- } \\
\text { less }\end{array}$ \\
\hline \multicolumn{9}{|c|}{01607500 South Fork South Branch Potomac River at Brandywine (BRANDYWINE) } \\
\hline 171 & Forest & 40 & 35 & 2 & 2 & 0.000 & 0.000 & 0 \\
\hline 172 & High till cropland & 40 & 35 & 2 & 2 & .000 & .000 & 0 \\
\hline 173 & Low till cropland & 40 & 35 & 2 & 2 & .000 & .000 & 0 \\
\hline 174 & Pasture & 40 & 35 & 2 & 2 & .000 & .000 & 0 \\
\hline 175 & Urban & 40 & 35 & 2 & 2 & .000 & .000 & 0 \\
\hline 176 & Hay & 40 & 35 & 2 & 2 & .000 & .000 & 0 \\
\hline \multicolumn{9}{|c|}{03052000 Middle Fork River at Audra (AUDRA) } \\
\hline 101 & Hardwood forest & 40 & 35 & 2 & 2 & 0.000 & 0.000 & 0 \\
\hline 102 & Shrubland & 40 & 35 & 2 & 2 & .000 & .000 & 0 \\
\hline 103 & Pasture / grassland & 40 & 35 & 2 & 2 & .000 & .000 & 0 \\
\hline 104 & $\begin{array}{l}\text { Row crop agricul- } \\
\text { ture }\end{array}$ & 40 & 35 & 2 & 2 & .000 & .000 & 0 \\
\hline 105 & Urban / developed & 40 & 35 & 2 & 2 & .000 & .000 & 0 \\
\hline 106 & Barren land & 40 & 35 & 2 & 2 & .000 & .000 & 0 \\
\hline 107 & Wetland & 40 & 35 & 2 & 2 & .000 & .000 & 0 \\
\hline 108 & Mined land & 40 & 35 & 2 & 2 & .000 & .000 & 0 \\
\hline 109 & Surface water & 40 & 35 & 2 & 2 & .000 & .000 & 0 \\
\hline 110 & Conifer forest & 40 & 35 & 2 & 2 & .000 & .000 & 0 \\
\hline \multicolumn{9}{|c|}{03061500 Buffalo Creek at Barrackville (BUFFALO) } \\
\hline 101 & Hardwood forest & 40 & 35 & 2 & 2 & 0.115 & 0.000 & 0 \\
\hline 102 & Shrubland & 40 & 35 & 2 & 2 & .115 & .000 & 0 \\
\hline 103 & Pasture / grassland & 40 & 35 & 2 & 2 & .115 & .000 & 0 \\
\hline 104 & Urban / developed & 40 & 35 & 2 & 2 & .115 & .000 & 0 \\
\hline 105 & Barren land & 40 & 35 & 2 & 2 & .115 & .000 & 0 \\
\hline 106 & Wetland & 40 & 35 & 2 & 2 & .115 & .000 & 0 \\
\hline 107 & Surface water & 40 & 35 & 2 & 2 & .115 & .000 & 0 \\
\hline 108 & Mined land & 40 & 35 & 2 & 2 & .115 & .000 & 0 \\
\hline
\end{tabular}


Table 9. Hydrologic Simulation Program-FORTRAN Model (HSPF) parameters for simulation of pervious land segments (PERLNDs), group 3 of subroutine named "PWATER," including the Brandywine Basin in West Virginia and Virginia, used in this study.-Continued

[PETMAX, air temperature below which evapotranspiration will be reduced if snow is simulated; PETMIN, air temperature below which evapotranspiration will be forced to zero if snow is simulated; INFEXP, exponent in the infiltration equation; INFILD, ratio between the maximum and mean infiltration capacities over the land segment; DEEPFR, fraction of ground-water inflow that flows to inactive ground water (varies by special action for values greater than zero for this study); BASETP, fraction of remaining potential evapotranspiration that can be satisfied from base flow; AGWETP, fraction of remaining potential evapotranspiration that can be satisfied from active ground-water storage; shaded table cells are the annual average of monthly values]

\begin{tabular}{|c|c|c|c|c|c|c|c|c|}
\hline $\begin{array}{l}\text { PERLND } \\
\text { number }\end{array}$ & $\begin{array}{l}\text { Land use/ } \\
\text { land cover }\end{array}$ & $\begin{array}{c}\text { PETMAX, } \\
\text { in degrees } \\
\text { Fahrenheit }\end{array}$ & $\begin{array}{l}\text { PETMIN, } \\
\text { in degrees } \\
\text { Fahrenheit }\end{array}$ & $\begin{array}{c}\text { INFEXP, } \\
\text { dimension- } \\
\text { less } \\
\end{array}$ & $\begin{array}{c}\text { INFILD, } \\
\text { dimension- } \\
\text { less }\end{array}$ & $\begin{array}{c}\text { DEEPFR, } \\
\text { dimension- } \\
\text { less } \\
\end{array}$ & $\begin{array}{c}\text { BASETP, } \\
\text { dimension- } \\
\text { less } \\
\end{array}$ & $\begin{array}{c}\text { AGWETP, } \\
\text { dimension- } \\
\text { less }\end{array}$ \\
\hline \multicolumn{9}{|c|}{03202750 Clear Fork at Clear Fork (CLEAR FORK) } \\
\hline 101 & Hardwood forest & 40 & 35 & 2 & 2 & 0.000 & 0.000 & 0 \\
\hline 102 & Shrubland & 40 & 35 & 2 & 2 & .000 & .000 & 0 \\
\hline 103 & $\begin{array}{l}\text { Row crop agricul- } \\
\text { ture }\end{array}$ & 40 & 35 & 2 & 2 & .000 & .000 & 0 \\
\hline 104 & Barren land & 40 & 35 & 2 & 2 & .000 & .000 & 0 \\
\hline 105 & Wetland & 40 & 35 & 2 & 2 & .000 & .000 & 0 \\
\hline 106 & Surface water & 40 & 35 & 2 & 2 & .000 & .000 & 0 \\
\hline 107 & Mined land & 40 & 35 & 2 & 2 & .000 & .000 & 0 \\
\hline 108 & Pasture / grassland & 40 & 35 & 2 & 2 & .000 & .000 & 0 \\
\hline 109 & Urban / developed & 40 & 35 & 2 & 2 & .000 & .000 & 0 \\
\hline \multicolumn{9}{|c|}{03206600 East Fork Twelvepole Creek near Dunlow (DUNLOW) } \\
\hline 101 & Hardwood forest & 40 & 35 & 2 & 2 & 0.229 & 0.005 & 0 \\
\hline 102 & Barren land & 40 & 35 & 2 & 2 & .000 & .005 & 0 \\
\hline 103 & Mined land & 40 & 35 & 2 & 2 & .000 & .005 & 0 \\
\hline 104 & Shrubland & 40 & 35 & 2 & 2 & .000 & .005 & 0 \\
\hline 105 & Pasture / grassland & 40 & 35 & 2 & 2 & .000 & .005 & 0 \\
\hline 106 & Urban / developed & 40 & 35 & 2 & 2 & .000 & .005 & 0 \\
\hline 107 & Surface water & 40 & 35 & 2 & 2 & .000 & .005 & 0 \\
\hline 108 & $\begin{array}{l}\text { Row crop agricul- } \\
\text { ture }\end{array}$ & 40 & 35 & 2 & 2 & .000 & .005 & 0 \\
\hline \multicolumn{9}{|c|}{03191500 Peters Creek near Lockwood (LOCKWOOD) } \\
\hline 101 & Hardwood forest & 40 & 35 & 2 & 2 & 0.000 & 0.005 & 0 \\
\hline 102 & Pasture / grassland & 40 & 35 & 2 & 2 & .000 & .005 & 0 \\
\hline 103 & Urban / developed & 40 & 35 & 2 & 2 & .000 & .005 & 0 \\
\hline 104 & Barren land & 40 & 35 & 2 & 2 & .000 & .005 & 0 \\
\hline 105 & Mined land & 40 & 35 & 2 & 2 & .000 & .005 & 0 \\
\hline 106 & $\begin{array}{l}\text { Row crop agricul- } \\
\text { ture }\end{array}$ & 40 & 35 & 2 & 2 & .000 & .005 & 0 \\
\hline 107 & Wetland & 40 & 35 & 2 & 2 & .000 & .005 & 0 \\
\hline 108 & Shrubland & 40 & 35 & 2 & 2 & .000 & .005 & 0 \\
\hline 109 & Surface water & 40 & 35 & 2 & 2 & .000 & .005 & 0 \\
\hline
\end{tabular}


Table 9. Hydrologic Simulation Program-FORTRAN Model (HSPF) parameters for simulation of pervious land segments (PERLNDs), group 3 of subroutine named "PWATER," including the Brandywine Basin in West Virginia and Virginia, used in this study.-Continued

[PETMAX, air temperature below which evapotranspiration will be reduced if snow is simulated; PETMIN, air temperature below which evapotranspiration will be forced to zero if snow is simulated; INFEXP, exponent in the infiltration equation; INFILD, ratio between the maximum and mean infiltration capacities over the land segment; DEEPFR, fraction of ground-water inflow that flows to inactive ground water (varies by special action for values greater than zero for this study); BASETP, fraction of remaining potential evapotranspiration that can be satisfied from base flow; AGWETP, fraction of remaining potential evapotranspiration that can be satisfied from active ground-water storage; shaded table cells are the annual average of monthly values]

\begin{tabular}{|c|c|c|c|c|c|c|c|c|}
\hline $\begin{array}{l}\text { PERLND } \\
\text { number }\end{array}$ & $\begin{array}{l}\text { Land use/ } \\
\text { land cover }\end{array}$ & $\begin{array}{c}\text { PETMAX, } \\
\text { in degrees } \\
\text { Fahrenheit }\end{array}$ & $\begin{array}{c}\text { PETMIN, } \\
\text { in degrees } \\
\text { Fahrenheit }\end{array}$ & $\begin{array}{c}\text { INFEXP, } \\
\text { dimension- } \\
\text { less }\end{array}$ & $\begin{array}{c}\text { INFILD, } \\
\text { dimension- } \\
\text { less }\end{array}$ & $\begin{array}{c}\text { DEEPFR, } \\
\text { dimension- } \\
\text { less }\end{array}$ & $\begin{array}{c}\text { BASETP, } \\
\text { dimension- } \\
\text { less }\end{array}$ & $\begin{array}{c}\text { AGWETP, } \\
\text { dimension- } \\
\text { less }\end{array}$ \\
\hline \multicolumn{9}{|c|}{03051500 Middle Fork at Midvale (MIDVALE) } \\
\hline 101 & Hardwood forest & 45 & 42 & 2 & 2 & 0.000 & 0.000 & 0 \\
\hline 102 & Shrubland & 45 & 42 & 2 & 2 & .000 & .000 & 0 \\
\hline 103 & Pasture / grassland & 45 & 42 & 2 & 2 & .000 & .000 & 0 \\
\hline 104 & $\begin{array}{l}\text { Row crop agricul- } \\
\text { ture }\end{array}$ & 45 & 42 & 2 & 2 & .000 & .000 & 0 \\
\hline 105 & Urban / developed & 45 & 42 & 2 & 2 & .000 & .000 & 0 \\
\hline 106 & Barren land & 45 & 42 & 2 & 2 & .000 & .000 & 0 \\
\hline 107 & Wetland & 45 & 42 & 2 & 2 & .000 & .000 & 0 \\
\hline 108 & Mined land & 45 & 42 & 2 & 2 & .000 & .000 & 0 \\
\hline 109 & Surface water & 45 & 42 & 2 & 2 & .000 & .000 & 0 \\
\hline 110 & Conifer forest & 45 & 42 & 2 & 2 & .000 & .000 & 0 \\
\hline \multicolumn{9}{|c|}{03213500 Panther Creek near Panther (PANTHER) } \\
\hline 101 & Hardwood forest & 40 & 35 & 2 & 2 & 0.000 & 0.000 & 0 \\
\hline 102 & Shrubland & 40 & 35 & 2 & 2 & .000 & .000 & 0 \\
\hline 103 & Pasture / grassland & 40 & 35 & 2 & 2 & .000 & .000 & 0 \\
\hline 104 & Urban / developed & 40 & 35 & 2 & 2 & .000 & .000 & 0 \\
\hline 105 & Barren land & 40 & 35 & 2 & 2 & .000 & .000 & 0 \\
\hline 106 & Mined land & 40 & 35 & 2 & 2 & .000 & .000 & 0 \\
\hline \multicolumn{9}{|c|}{03192200 Twentymile Creek at Vaughan (VAUGHAN) } \\
\hline 101 & Hardwood forest & 40 & 35 & 2 & 2 & 0.333 & 0.005 & 0 \\
\hline 102 & Pasture / grassland & 40 & 35 & 2 & 2 & .333 & .005 & 0 \\
\hline 103 & Barren land & 40 & 35 & 2 & 2 & .333 & .005 & 0 \\
\hline 104 & Mined land & 40 & 35 & 2 & 2 & .333 & .005 & 0 \\
\hline 105 & Shrubland & 40 & 35 & 2 & 2 & .333 & .005 & 0 \\
\hline 106 & Urban / developed & 40 & 35 & 2 & 2 & .333 & .005 & 0 \\
\hline 107 & Surface water & 40 & 35 & 2 & 2 & .333 & .005 & 0 \\
\hline 108 & Wetland & 40 & 35 & 2 & 2 & .333 & .005 & 0 \\
\hline
\end{tabular}


Table 10. Hydrologic Simulation Program-FORTRAN Model (HSPF) parameters for simulation of pervious land segments (PERLNDs), group 4 of subroutine named "PWATER," including the Brandywine Basin in West Virginia and Virginia, used in this study.

[CEPSC, interception storage capacity; UZSN, upper-zone nominal storage; NSUR, Manning's roughness for the overland flow plane; INTFW, interflow inflow parameter; IRC, interflow recession parameter; LZETP, lower-zone evapotranspiration parameter; shaded table cells are the annual average of monthly values]

\begin{tabular}{|c|c|c|c|c|c|c|c|}
\hline $\begin{array}{l}\text { PERLND } \\
\text { number }\end{array}$ & Land use/land cover & $\begin{array}{l}\text { CEPSC, in } \\
\text { inches }\end{array}$ & $\begin{array}{l}\text { UZSN, in } \\
\text { inches }\end{array}$ & $\begin{array}{c}\text { NSUR, } \\
\text { dimension- } \\
\text { less }\end{array}$ & $\begin{array}{c}\text { INTFW, } \\
\text { dimension- } \\
\text { less }\end{array}$ & IRC, in day ${ }^{-1}$ & $\begin{array}{c}\text { LZETP, } \\
\text { dimension- } \\
\text { less }\end{array}$ \\
\hline \multicolumn{8}{|c|}{01607500 South Fork South Branch Potomac River at Brandywine (BRANDYWINE) } \\
\hline 171 & Forest & 0.108 & 0.800 & 0.3500 & 1.70 & 0.650 & 0.400 \\
\hline 172 & High till cropland & .063 & .282 & .0920 & 1.40 & .600 & .271 \\
\hline 173 & Low till cropland & .096 & .373 & .2030 & 1.40 & 600 & .271 \\
\hline 174 & Pasture & .079 & .400 & .1500 & 1.40 & .600 & .400 \\
\hline 175 & Urban & .094 & .400 & .1000 & 1.40 & 600 & .400 \\
\hline 176 & Hay & .079 & .400 & .1500 & 1.40 & .600 & .400 \\
\hline \multicolumn{8}{|c|}{03052000 Middle Fork River at Audra (AUDRA) } \\
\hline 101 & Hardwood forest & 0.055 & 0.769 & 0.1750 & 1.53 & 0.260 & 0.289 \\
\hline 102 & Shrubland & .055 & .769 & .1750 & 1.53 & .260 & .289 \\
\hline 103 & Pasture / grassland & .055 & .769 & .0750 & 1.26 & .240 & .289 \\
\hline 104 & Row crop agriculture & .055 & .769 & .1450 & 1.26 & .240 & .289 \\
\hline 105 & Urban / developed & .055 & .769 & .0500 & 1.26 & .240 & .289 \\
\hline 106 & Barren land & .055 & .769 & .1750 & 1.53 & .260 & .289 \\
\hline 107 & Wetland & .055 & 1.128 & .2000 & .75 & .500 & .289 \\
\hline 108 & Mined land & .055 & 1.128 & .2000 & .75 & .500 & .289 \\
\hline 109 & Surface water & .055 & 1.128 & .2000 & .75 & .500 & .289 \\
\hline 110 & Conifer forest & .055 & 1.128 & .1750 & 1.53 & .260 & .289 \\
\hline \multicolumn{8}{|c|}{03061500 Buffalo Creek at Barrackville (BUFFALO) } \\
\hline 101 & Hardwood forest & 0.068 & 1.039 & 0.2000 & 1.36 & 0.065 & 0.302 \\
\hline 102 & Shrubland & .068 & 1.039 & .2000 & 1.36 & .065 & .302 \\
\hline 103 & Pasture / grassland & .068 & 1.039 & .1500 & 1.12 & .060 & .302 \\
\hline 104 & Urban / developed & .068 & 1.039 & .0200 & 1.12 & .060 & .302 \\
\hline 105 & Barren land & .068 & 1.039 & .2000 & 1.36 & .065 & .302 \\
\hline 106 & Wetland & .100 & 1.039 & .2000 & .75 & .050 & .302 \\
\hline 107 & Surface water & .100 & 1.039 & .0200 & .75 & .050 & .302 \\
\hline 108 & Mined land & .100 & 1.039 & .1000 & .75 & .090 & .302 \\
\hline
\end{tabular}


Table 10. Hydrologic Simulation Program-FORTRAN Model (HSPF) parameters for simulation of pervious land segments (PERLNDs), group 4 of subroutine named "PWATER," including the Brandywine Basin in West Virginia and Virginia, used in this study.-Continued

[CEPSC, interception storage capacity; UZSN, upper-zone nominal storage; NSUR, Manning's roughness for the overland flow plane; INTFW, interflow inflow parameter; IRC, interflow recession parameter; LZETP, lower-zone evapotranspiration parameter; shaded table cells are the annual average of monthly values]

\begin{tabular}{|c|c|c|c|c|c|c|c|}
\hline $\begin{array}{l}\text { PERLND } \\
\text { number }\end{array}$ & Land use/land cover & $\begin{array}{l}\text { CEPSC, in } \\
\text { inches }\end{array}$ & $\begin{array}{l}\text { UZSN, in } \\
\text { inches }\end{array}$ & $\begin{array}{c}\text { NSUR, } \\
\text { dimension- } \\
\text { less }\end{array}$ & $\begin{array}{c}\text { INTFW, } \\
\text { dimension- } \\
\text { less }\end{array}$ & IRC, in day ${ }^{-1}$ & $\begin{array}{c}\text { LZETP, } \\
\text { dimension- } \\
\text { less }\end{array}$ \\
\hline \multicolumn{8}{|c|}{03202750 Clear Fork at Clear Fork (CLEAR FORK) } \\
\hline 101 & Hardwood forest & 0.024 & 0.223 & 0.3500 & 2.50 & 0.100 & 0.402 \\
\hline 102 & Shrubland & .024 & .223 & .3500 & 2.50 & .100 & .402 \\
\hline 103 & Row crop agriculture & .203 & .223 & .2000 & 2.10 & .090 & .228 \\
\hline 104 & Barren land & .203 & .223 & .3500 & 2.50 & .100 & .228 \\
\hline 105 & Wetland & .203 & 1.128 & .2000 & .75 & .050 & .228 \\
\hline 106 & Surface water & .203 & 1.128 & .2000 & .75 & .500 & .228 \\
\hline 107 & Mined land & .203 & 1.128 & .0200 & .05 & .050 & .228 \\
\hline 108 & Pasture / grassland & .203 & .200 & .2000 & 2.10 & .090 & .228 \\
\hline 109 & Urban / developed & .000 & .020 & .0200 & .50 & .020 & .228 \\
\hline \multicolumn{8}{|c|}{03206600 East Fork Twelvepole Creek near Dunlow (DUNLOW) } \\
\hline 101 & Hardwood forest & 0.045 & 0.479 & 0.4320 & 3.40 & 0.130 & 0.432 \\
\hline 102 & Barren land & .057 & .479 & .3000 & 2.80 & .120 & .228 \\
\hline 103 & Mined land & .000 & .479 & .2000 & 2.80 & .120 & .228 \\
\hline 104 & Shrubland & .057 & .479 & .3000 & 2.80 & .120 & .228 \\
\hline 105 & Pasture / grassland & .057 & .479 & .3000 & 2.80 & .120 & .228 \\
\hline 106 & Urban / developed & .060 & .479 & .2000 & 2.80 & .120 & .228 \\
\hline 107 & Surface water & .000 & .479 & .2000 & .75 & .500 & .228 \\
\hline 108 & Row crop agriculture & .071 & .479 & .2030 & 2.80 & .120 & .228 \\
\hline \multicolumn{8}{|c|}{03191500 Peters Creek near Lockwood (LOCKWOOD) } \\
\hline 101 & Hardwood forest & 0.042 & 0.775 & 0.1750 & 1.70 & 0.260 & 0.376 \\
\hline 102 & Pasture / grassland & .042 & .775 & .0750 & 1.40 & .240 & .376 \\
\hline 103 & Urban / developed & .042 & .775 & .0500 & 1.40 & .240 & .376 \\
\hline 104 & Barren land & .042 & .775 & .1750 & 1.70 & .260 & .376 \\
\hline 105 & Mined land & .100 & .775 & .2000 & .75 & .500 & .376 \\
\hline 106 & Row crop agriculture & .042 & .775 & .0725 & 1.40 & .240 & .376 \\
\hline 107 & Wetland & .100 & .775 & .2000 & .75 & .500 & .376 \\
\hline 108 & Shrubland & .042 & .775 & .1750 & 1.70 & .260 & .376 \\
\hline 109 & Surface water & .100 & .775 & .2000 & .75 & .500 & .376 \\
\hline
\end{tabular}


Table 10. Hydrologic Simulation Program-FORTRAN Model (HSPF) parameters for simulation of pervious land segments (PERLNDs), group 4 of subroutine named "PWATER," including the Brandywine Basin in West Virginia and Virginia, used in this study.-Continued

[CEPSC, interception storage capacity; UZSN, upper-zone nominal storage; NSUR, Manning's roughness for the overland flow plane; INTFW, interflow inflow parameter; IRC, interflow recession parameter; LZETP, lower-zone evapotranspiration parameter; shaded table cells are the annual average of monthly values]

\begin{tabular}{|c|c|c|c|c|c|c|c|}
\hline $\begin{array}{l}\text { PERLND } \\
\text { number }\end{array}$ & Land use/land cover & $\begin{array}{l}\text { CEPSC, in } \\
\text { inches }\end{array}$ & $\begin{array}{c}\text { UZSN, in } \\
\text { inches }\end{array}$ & $\begin{array}{c}\text { NSUR, } \\
\text { dimension- } \\
\text { less }\end{array}$ & $\begin{array}{l}\text { INTFW, } \\
\text { dimension- } \\
\text { less }\end{array}$ & IRC, in day ${ }^{-1}$ & $\begin{array}{c}\text { LZETP, } \\
\text { dimension- } \\
\text { less }\end{array}$ \\
\hline \multicolumn{8}{|c|}{03051500 Middle Fork at Midvale (MIDVALE) } \\
\hline 101 & Hardwood forest & 0.035 & 0.802 & 0.3500 & 0.68 & 0.390 & 0.376 \\
\hline 102 & Shrubland & .035 & .802 & .3500 & .68 & .390 & .376 \\
\hline 103 & Pasture / grassland & .100 & .802 & .1500 & .56 & .360 & .376 \\
\hline 104 & Row crop agriculture & .100 & .802 & .0900 & .56 & .360 & .376 \\
\hline 105 & Urban / developed & .100 & .802 & .1000 & .56 & .360 & .376 \\
\hline 106 & Barren land & .035 & .802 & .3500 & .68 & .360 & .376 \\
\hline 107 & Wetland & .100 & .802 & .2000 & .75 & .500 & .376 \\
\hline 108 & Mined land & .100 & .802 & .2000 & .75 & .500 & .376 \\
\hline 109 & Surface water & .100 & .802 & .2000 & .75 & .500 & .376 \\
\hline 110 & Conifer forest & .035 & .802 & .3500 & .68 & .390 & .376 \\
\hline \multicolumn{8}{|c|}{03213500 Panther Creek near Panther (PANTHER) } \\
\hline 101 & Hardwood forest & 0.040 & 0.121 & 0.3500 & 1.70 & 0.325 & 0.403 \\
\hline 102 & Shrubland & .040 & .121 & .3500 & 1.70 & .325 & .403 \\
\hline 103 & Pasture / grassland & .040 & .121 & .1500 & 1.40 & .300 & .228 \\
\hline 104 & Urban / developed & .040 & .121 & .1000 & 1.40 & .300 & .228 \\
\hline 105 & Barren land & .040 & .121 & .3500 & 1.70 & .325 & .228 \\
\hline 106 & Mined land & .040 & .121 & .2000 & .75 & .325 & .228 \\
\hline \multicolumn{8}{|c|}{03192200 Twentymile Creek at Vaughan (VAUGHAN) } \\
\hline 101 & Hardwood forest & 0.042 & 0.775 & 0.1750 & 1.70 & 0.260 & 0.376 \\
\hline 102 & Pasture / grassland & .042 & .775 & .0750 & 1.40 & .240 & .376 \\
\hline 103 & Barren land & .042 & .775 & .1750 & 1.70 & .260 & .376 \\
\hline 104 & Mined land & .010 & .775 & .7500 & .75 & .900 & .376 \\
\hline 105 & Shrubland & .042 & .775 & .1750 & 1.70 & .260 & .376 \\
\hline 106 & Urban / developed & .042 & .775 & .2000 & .75 & .500 & .376 \\
\hline 107 & Surface water & .100 & .775 & .2000 & .75 & .500 & .376 \\
\hline 108 & Wetland & .100 & .775 & .2000 & .75 & .500 & .376 \\
\hline
\end{tabular}


Table 11. Summary of major calibration parameters for selected land-use/land-cover classifications used in this study.

[CSNOFG is 1 if snow accumulation and melt are being considered; RTOPFG is 1 if routing of overland flow is computed as in predecessor models; UZFG is 1 if upper-zone inflow is computed as in predecessor models; VCSFG is 1 if interception storage capacity can vary monthly; VUZFG is 1 if upper-zone nominal storage can vary monthly; VNNFG is 1 if Manning's roughness for the overland flow plane can vary monthly; VIFWFG is 1 if interflow inflow parameter can vary monthly and 0 if constant; FOREST, indicates the fraction of the land segment covered by forest transpiring in winter; LZSN, nominal capacity of the lower-zone storage; INFILT, index to the infiltration capacity of the soil; LSUR, length of the overland flow plane; SLSUR, slope of the overland flow plane; KVARY, indicates the behavior of the ground-water recession flow; AGWRC, basic ground-water recession rate; PETMAX, air temperature below which evapotranspiration will be reduced if snow is simulated; PETMIN, air temperature below which evapotranspiration will be forced to zero if snow is simulated; INFEXP, exponent in the infiltration equation; INFILD, ratio between the maximum and mean infiltration capacities over the land segment; DEEPFR, fraction of ground-water inflow that flows to inactive ground water; BASETP, fraction of the remaining potential evapotranspiration that can be satisfied from base flow; AGWETP, fraction of remaining potential evapotranspiration that can be satisfied from active ground-water storage; CEPSC,interception storage capacity; UZSN, nominal capacity of the upper-zone storage; NSUR, Manning's roughness of the land surface; INTFW, interflow inflow; IRC, interflow recession constant; LZETP, lower-zone evapotranspiration]

\begin{tabular}{|c|c|c|c|c|c|c|c|c|c|c|}
\hline \multirow{3}{*}{ Parameter } & \multicolumn{10}{|c|}{ Land-use/land-cover classification } \\
\hline & \multicolumn{2}{|c|}{$\begin{array}{l}\text { Hardwood } \\
\text { forest }\end{array}$} & \multicolumn{2}{|c|}{$\begin{array}{l}\text { Pasture/ } \\
\text { grassland }\end{array}$} & \multicolumn{2}{|c|}{$\begin{array}{l}\text { Row crop } \\
\text { agriculture }\end{array}$} & \multicolumn{2}{|c|}{$\begin{array}{c}\text { Urban/ } \\
\text { developed }\end{array}$} & \multicolumn{2}{|c|}{ Mined land } \\
\hline & $\begin{array}{c}\text { Maxi- } \\
\text { mum }\end{array}$ & $\begin{array}{c}\text { Mini- } \\
\text { mum }\end{array}$ & $\begin{array}{c}\text { Maxi- } \\
\text { mum }\end{array}$ & $\begin{array}{c}\text { Mini- } \\
\text { mum }\end{array}$ & $\begin{array}{c}\text { Maxi- } \\
\text { mum }\end{array}$ & $\begin{array}{l}\text { Mini- } \\
\text { mum }\end{array}$ & $\begin{array}{c}\text { Maxi- } \\
\text { mum }\end{array}$ & $\begin{array}{c}\text { Mini- } \\
\text { mum }\end{array}$ & $\begin{array}{c}\text { Maxi- } \\
\text { mum }\end{array}$ & $\begin{array}{l}\text { Mini- } \\
\text { mum }\end{array}$ \\
\hline CSNOFG, dimensioless & 1 & 0 & 1 & 0 & 1 & 1 & 1 & 0 & 1 & 0 \\
\hline RTOPFG, dimensionless & 1 & 1 & 1 & 1 & 1 & 1 & 1 & 1 & 1 & 1 \\
\hline UZFG, dimensionless & 1 & 1 & 1 & 1 & 1 & 1 & 1 & 1 & 1 & 1 \\
\hline VCSFG, dimensionless & 1 & 1 & 1 & 1 & 1 & 1 & 1 & 0 & 1 & 1 \\
\hline VUZFG, dimensionless & 1 & 0 & 1 & 0 & 1 & 1 & 1 & 0 & 1 & 0 \\
\hline VNNFG, dimensionless & 1 & 0 & 0 & 0 & 1 & 0 & 0 & 0 & 0 & 0 \\
\hline VIFWFG, dimensionless & 0 & 0 & 0 & 0 & 0 & 0 & 0 & 0 & 0 & 0 \\
\hline FOREST, dimensionless & .3 & .0 & .3 & .0 & .1 & .0 & .3 & .0 & .4 & .0 \\
\hline LZSN, in inches & 5.0 & 1.5 & 5.0 & 5.0 & 5.0 & 5.0 & 5.0 & 1.0 & 10.0 & 2.0 \\
\hline INFILT, in inches per day & .1220 & .0290 & .0900 & .0187 & .0850 & .0340 & .8000 & .0010 & .9500 & .1600 \\
\hline LSUR, in feet & 800 & 10 & 500 & 10 & 600 & 150 & 600 & 10 & 400 & 75 \\
\hline SLSUR, in foot per foot & .5697 & .2368 & .5689 & .2368 & .5689 & .3415 & .5857 & .0800 & .5689 & .2340 \\
\hline KVARY, in inches ${ }^{-1}$ & 4.7 & .0 & 4.7 & .0 & 4.5 & 1.0 & 4.5 & .0 & 4.5 & .0 \\
\hline AGWRC, in day ${ }^{-1}$ & .980 & .910 & .980 & .910 & .980 & .910 & .990 & .910 & .990 & .935 \\
\hline $\begin{array}{l}\text { PETMAX, in degrees } \\
\text { Fahrenheit }\end{array}$ & 45 & 40 & 45 & 40 & 45 & 40 & 45 & 40 & 45 & 40 \\
\hline $\begin{array}{l}\text { PETMIN, in degrees } \\
\text { Fahrenheit }\end{array}$ & 42 & 35 & 42 & 35 & 42 & 35 & 42 & 35 & 42 & 35 \\
\hline INFEXP, dimensionless & 2 & 2 & 2 & 2 & 2 & 2 & 2 & 2 & 2 & 2 \\
\hline INFILD, dimensionless & 2 & 2 & 2 & 2 & 2 & 2 & 2 & 2 & 2 & 2 \\
\hline DEEPFR, dimensionless & .4 & .0 & .4 & .0 & .0 & .0 & .4 & .0 & .4 & .0 \\
\hline BASETP, dimensionless & .005 & .000 & .005 & .000 & .005 & .000 & .005 & .000 & .005 & .000 \\
\hline $\begin{array}{l}\text { AGWETP, } \\
\text { dimensionless }\end{array}$ & 0 & 0 & 0 & 0 & 0 & 0 & 0 & 0 & 0 & 0 \\
\hline CEPSC, in inches & .1 & .0 & .1 & .0 & .1 & .0 & .1 & 0.0 & .1 & 0.0 \\
\hline UZSN, in inches & 1.1280 & .2067 & 1.1280 & .2000 & 1.1280 & .2067 & 1.1280 & .0200 & 1.1280 & .2067 \\
\hline NSUR, dimensionless & .7725 & .1750 & .3000 & .0750 & .2000 & .0183 & .2000 & .0200 & .7500 & .0200 \\
\hline INTFW, dimensionless & 3.40 & .68 & 2.80 & .56 & 2.80 & .56 & 2.80 & .50 & 2.80 & .05 \\
\hline IRC, in day ${ }^{-1}$ & .39 & .065 & .36 & .06 & .36 & .09 & .50 & .02 & .90 & .05 \\
\hline LZETP, dimensionless & .9 & .1 & .9 & .1 & .9 & .1 & .9 & .1 & .9 & .1 \\
\hline
\end{tabular}




\section{Summary}

In 2001West Virginia was ranked as the second largest coal-producing State, accounting for about 15 percent of the total coal production in the United States. The surface-mining technique called mountaintop removal (steep-slope, mountaintop-mining, and multiple-seam mining) largely accounts for an increase in coal production in the 1990s. The West Virginia Department of Environmental Protection, Division of Mining and Reclamation (WVDEP/DMR) is assessing the cumulative hydrologic impacts of coal mining in 240 basins with drainage areas between approximately 30 and $80 \mathrm{mi} 2$ in the coal-mining region of West Virginia. The U.S. Geological Survey, in cooperation with WVDEP/DMR began a study in 2003 to apply the HSPF model to selected basins within and adjacent to these 240 basins.

The HSPF model was applied to eight basins in the coalmining region of West Virginia to determine the magnitude and characteristics of model parameters used for simulating streamflow. The eight basins were selected from those with a USGS streamflow-gaging station at the terminus. Those stations selected had long record periods, including mined and unmined record periods. The stations also are well distributed across the coal-mining region. Results of this study will be useful for simulating the cumulative impacts of coal mining on streamflow for other basins in West Virginia.

The eight basins were delineated into subbasins and stream reaches using BASINS software. Ten land-use/landcover classifications were determined as hardwood forest, shrubland, pasture/grassland, row-crop agriculture, urban/ developed, barren land, wetland, mined land, surface water, and conifer forest.

Initial estimates of parameter values were based on those used for a model simulating the South Fork South Branch Potomac River at Brandywine by the Chesapeake Bay Project. Parameters values were adjusted by evaluating daily, monthly, and seasonal hydrographs; statistical comparisons; and automated advice from the expert system of the HSPF modeling software.

The HSPF parameter for fraction of ground-water inflow that flows to inactive ground water, DEEPFR, was given special action to allow for values greater than zero during autumn. The basis for this special action was related to the seasonal movement of the water table and transpiration of trees.

The HSPF parameter for nominal capacity of the upperzone storage, UZSN, increased as the latitude of the basin location increased. The correlation between values of UZSN and latitude could be due to decreasing slopes, decreasing rockiness of the soils, and increasing soil depths from south to north.

The characteristics of major parameters for the prevalent land use, hardwood forest, were examined, including relations among parameters and relative sensitivity to model calibrations. The models were most sensitive to DEEPFR and the parameter for interception storage capacity, CEPSC. The models were also fairly sensitive to the parameters representing an index of the infiltration capacity of the soil, INFILT; the non-linearizing parameter of the ground-water recession flow, KVARY; the basic ground water recession rate, AGWRC; the nominal capacity of the upper zone storage, UZSN; the interflow inflow coefficient, INTFW, the interflow recession parameter, IRC; and the parameter for lower-zone evapotranspiration, LZETP. The major parameters for all land-use/landcover classifications were presented for the eight basins, and a summary of the parameters was tabulated. The parameter values presented can be used as a reference for developing HSPF models for other basins in the coal-mining region of West Virginia.

Models for six of the eight study basins were verified by computing streamflow for a time period not used for calibration. The verification was quantified by statistical measures and indicated good model-simulation results. The verification for CLEAR FORK was probably affected by continued mining and development, but also by the difficulty that the rainfall time-series and observed runoff had opposite trends.

\section{Acknowledgments}

The authors thanks Nick Schaer with WVDEP/DMR for his assistance in providing information on mining operations throughout the State and advice on basins for model application. The authors would also like to thank the staff at the Natural Resource Analysis Center (NRAC) associated with West Virginia University, particularly Jerry Fletcher, Bob Eli, and Mike Strager, for assistance in gathering data; designing project goals; determining criteria for modeling, including selection of categories for pervious land surfaces; providing geographic information system (GIS) tools; facilitating and providing training; and selecting basins for model application. The authors also wish to extend appreciation to Kate Flynn of the USGS for assistance with all matters related to HSPF. We also thank Anthony Donigian, Brian Bicknell, and others of AQUA TERRA Consultants in Decatur, Ga., for assistance during the workshop entitled "HSPF Use for Cumulative Hydrologic Impact Assessments of Coal Mining in West Virginia," at West Virginia University, March 4 and 5, 2003.

Special thanks are expressed to James Sams of the USGS whose advice and previous HSPF study (Sams and Whitt, 1995) were of great value, especially in the early months of this effort. 


\section{Selected References}

Bicknell, B.R., Imhoff, J.C., Kittle, J.L., Jr., Jobes, T.H., and Donigian, A.S., Jr., 2001, HSPF Version 12 User's Manual: Mountain View, Calif., AQUA TERRA Consultants, 845 p.

Borchers, J.W., Ehlke, T.A., Mathes, M.V., and Downes, S.C., 1991, The effects of coal mining on the hydrologic environment of selected stream basins in southern West Virginia: U.S. Geological Survey Water-Resources Investigations Report 84-4300, 119 p.

Chow, V.T., ed., 1964, Handbook of applied hydrology: New York, McGraw-Hill, p. 9-57.

Donigian, A.S. Jr., Imhoff, J.C., and Kittle, J.L., Jr., 1999. HSPFParm-An Interactive Database of HSPF Model Parameters: Washington, D.C., U.S. Environmental Protection Agency, EPA-823-R-99-004, 40 p.

Donigian, A.S. Jr., Imhoff, J.C., and Kittle, J.L., Jr., 2000, HSPFParm, Version 1.2b1.

Donigian, A.S., Jr. and Imhoff, J.C., 2002. From the Stanford Model to BASINS-40 Years of Watershed Modeling, ASCE Task Committee on Evolution of Hydrologic Methods Through Computers, ASCE 150th Anniversary Celebration. November 3-7, 2002: Washington, D.C., accessed July 16, 2004, at http://www.aquaterra.com/publications.html

Duan, Q., M. Smith and J. Schaake, 2003, Testing and evaluation of potential evapotranspiration schemes for National Weather Service River Forecast System: Seventeenth Conference on Hydrology, Long Beach, CA, extended abstract accessed June 16, 2005 at http://ams.confex.com/ams/pdfpapers/54504.pdf, 4 p.

ESRI, 2002, ArcView 3.3 Now available, May 29, 2002, Press Release: Redlands, Calif., Environmental Systems Research Institute, Inc., accessed July 27, 2004, at http://www.esri. com/news/releases/02_2qtr/arcview33.html

Farnsworth, R.K., Thompson, E.S., and Peck, E.L., 1982, Evaporation atlas for the contiguous 48 United States: National Oceanic and Atmospheric Administration Technical Report NWS 33, 26 p.

Fenneman, N.M., 1938, Physiography of the Eastern United States: New York, McGraw-Hill, 714 p.

Fenneman, N.M., and Johnson, D.W., 1946, Physical division of the United States: U.S. Geological Survey, Physiography Committee Special Map, scale 1:7,000,000.

Freeze, R.A., and Cherry, J.A., 1979, Groundwater: Englewood Cliffs, N.J., Prentice-Hall, Inc., 604 p.
Greene, K., and Linker, L.C., 1998, Chesapeake Bay watershed model application \& calculation of nutrient \& sediment loadings, Appendix A-Phase IV Chesapeake Bay Watershed Model Hydrology Calibration Results Report of the Modeling Subcommittee: Annapolis, Md., Chesapeake Bay Program Office, EPA 903-R-98-004. CBP/TRS 196/98, accessed July 16, 2004, at http://www.chesapeakebay. net/pubs/113.pdf

Harlow, G.E., and LeCain, G.D., 1993, Hydrologic characteristics of, and ground water flow in, coal bearing rocks of southwestern Virginia: U.S. Geological Survey Water-Supply Paper 2388, 36 p.

Haro, R.J., and Brusven, M.A., 1994, Effects of cobble embeddedness on the microdistribution of the sculpin Cottus beldingi and its stonefly prey: Great Basin Naturalist, v. 54, no. 1, p. 64-70.

Hershfield, D.M., 1961, Rainfall frequency atlas of the United States for durations from 30 minutes to 24 hours and return periods from 1 to 100 years: U.S. Department of Commerce, Weather Bureau Technical Paper No. 40, May 1961, p. 6.

Hobba, W.A., Jr., and Suder, K.E., 1987, National Water Summary 1987-Water supply and use: West Virginia, 7 p., (in Carr, J.E., Chase, E.B., Paulson, R.W., and Moody, D.W., 1990), National water summary 1987-Hydrologic events and water supply and use: U.S. Geological Survey WaterSupply Paper 2350, 552 p.

Hobba, W.A., Jr., 1981, Effects of underground mining and mine collapse on the hydrology of selected basins in West Virginia: West Virginia Geologic and Economic Survey Report of Investigations RI-33, 77 p.

Hummel, J.K., Jr., and Gray, M., 2001, WDMUtil Version 2.0-A tool for managing watershed modeling time-series data, User's Manual: Decatur, Ga., AQUA TERRA Consultants, $157 \mathrm{p}$.

Krug, W.R., Gebert, W.A., Graczyk, D.J., Stevens, D.L., Jr., Rochelle, B.P, and Church, M.R., 1990, Map of mean annual runoff for the northeastern, southeastern, mid-Atlantic United States, Water years 1951-80: U.S. Geological Survey Water-Resources Investigations Report 88-4094, 11 p.

Lahlou, M., Shoemaker, L., Choudhury, S., Elmer, R., Hu, A., Manguerra, H., and Parker, A., 1998, BASINS-Better Assessment Science Integrating Nonpoint and point Source, user's manual, version 2.0: Fairfax, Va., U.S. Environmental Protection Agency, EPA-823-B-98-006, 360 p.

Leavesley, G.H., Lichty, R.W., Troutman, B.M., and Saindon, L.G., 1983, Precipitation-Runoff Modeling System: User's Manual: U.S. Geological Survey Water-Resources Investigations 83-4238, $207 \mathrm{p}$. 
Lumb, A.M., McCammon, R.B., and Kittle, J.L., Jr., 1994, Users manual for an Expert System (HSPEXP) for calibration of the Hydrological Simulation Program-Fortran: U.S. Geological Survey Water-Resources Investigations Report 94-4168, 102 p.

Messinger, Terence, 2002, Comparison of storm response of streams in small, unmined and valley-filled watersheds, 1999-2001, Ballard Fork, West Virginia: U.S. Geological Survey Water-Resources Investigations Report 02-4303, 22 p.

Messinger, Terence, and Paybins, K.S., 2003, Relations between precipitation and daily and monthly mean flows in gaged, unmined and valley-filled watersheds, Ballard Fork, West Virginia, 1999-2001: U.S. Geological Survey WaterResources Investigations Report 03-4113, 57 p.

National Oceanic and Atmospheric Administration, 1996, Climatological data annual summary for West Virginia: v. 104, no. 13, 22 p.

National Oceanic and Atmospheric Administration, [2001?], Untitled original documentation of the National Weather Service River Forecast System Synoptic Data Transfer (SYNTRAN) utility computer program, accessed June 17, 2005 at http://dipper.nws.noaa.gov/hdsb/data/archived/legacy/syntran.html, 1 p.

Office of Surface Mining Reclamation and Enforcement, 2003, Annual evaluation summary report for the regulatory and abandoned mine land reclamation program administered by the state of West Virginia for evaluation year 2002, October 1, 2001, to September 30, 2002: Charleston, W.Va., $37 \mathrm{p}$.

Puente, Celso, and Atkins, J.T., 1989, Simulation of rainfallrunoff response in mined and unmined watersheds in coal areas of West Virginia: U.S. Geological Survey Water-Supply Paper 2289, 48 p.

Rango, A., and Martinec, J., 1995, Revisiting the degree-day method for snowmelt computations: Water Resources Bulletin, v. 31, no. 4, p. 657-669.

Sams, J.I., III, and Witt, E.C., III, 1995, Simulation of streamflow and sediment

transport in two surface-coal-mined basins in Fayette County, Pennsylvania: U.S. Geological Survey WaterResources Investigations Report 92-4093, 52 p.

U.S. Department of Commerce, 1960, Climates of the states, West Virginia: Weather Bureau, Climatography of the United States, no. 60-46, 15 p.

U.S. Department of Commerce, 1961, Rainfall frequency atlas of the United States: Weather Bureau Technical Paper no. $40,115 \mathrm{p}$.
U.S. Department of Commerce, 1968, Climatic atlas of the United States: Environmental Data Service, 80 p.

U.S. Environmental Protection Agency, 1996, Hydrologic simulation program-FORTRAN (HSPF): Users Manual for release 11: Environmental Research Laboratory, 760 p.

U.S. Environmental Protection Agency, 1999, Using HSPEXP with BASINS/NPSM BASINS, Technical Note 5: U.S. Environmental Protection Agency, EPA-823-R-99-010, $14 \mathrm{p}$.

U.S. Environmental Protection Agency, 2000, BASINS Technical Note 6-Estimating hydrology and hydraulic parameters for HSPF: U.S. Environmental Protection Agency, EPA-823-R00-012, 32 p.

U.S. Environmental Protection Agency, 2004a, http://www. chesapeakebay.net/temporary/mdsc/community_model/allwdm.tar.Z, accessed July 16, 2004.

U.S. Environmental Protection Agency, 2004b, HSPFParm Version 1.3 beta of July 2002, http://www.epa.gov/OST/ BASINS/ or http://www.epa.gov/waterscience/ftp/basins/ HSPFParm/, accessed July 16, 2004.

U.S. Geological Survey, 1970, The national atlas of the United States of America: U.S. Geological Survey, 417 p.

U.S. Geological Survey, 1991, National water summary 1988-89-Hydrologic events and floods and droughts: U.S. Geological Survey Water-Supply Paper 2375, 591 p.

Wang, P., Storrick, J., and Linker, L.C., 1997, Chesapeake Bay Watershed model application and calculations of nutrient and sediment loadings, Appendix D-Phase IV Chesapeake Bay Watershed model precipitation and meteorological data development and atmospheric nutrient deposition report of the Modeling Subcommittee, August, 1997: Annapolis, Md., 58 p., accessed July 16, 2004, at http://www.chesapeakebay.net/pubs/112.pdf

Ward, P.E., and Wilmoth, B.M., 1968, Ground-water hydrology of the Monongahela River basin in West Virginia: West Virginia Geological and Economical Survey River Basin Bulletin 1, 54 p.

Wiley, J.B., Atkins, J.T., Jr., and Tasker, G.D., 2000, Estimating magnitude and frequency of peak discharges for rural, unregulated, streams in West Virginia: U.S. Geological Survey Water-Resources Investigations Report 00-4080, 93 p.

Wiley, J.B., and Brogan, F.B, 2003, Comparison of peak discharges among sites with and without valley fills for the July 8-9, 2001, flood in the headwaters of Clear Fork, Coal River basin, mountaintop coal-mining region, southern West Virginia: U.S. Geological Survey Open-File Report 03-133, $12 \mathrm{p}$. 
Wiley, J.B., Evaldi, R.D., Eychaner, J.H., and Chambers, D.B., 2001, Reconnaissance of stream geomorphology, low streamflow, and stream temperature in the mountaintop coal-mining region, southern West Virginia: U.S. Geological Survey Water-Resources Investigations Report 01-4092, $34 \mathrm{p}$.

Wyrick, G.G., and Borchers, J.W., 1981, Hydrologic effects of stress-relief fracturing in an Appalachian Valley: U.S. Geological Survey Water-Supply Paper 2177, 51 p.

\section{Abbreviations and acronyms}

AGWETP HSPF parameter for the fraction of remaining potential evapotranspiration that can be satisfied from active ground-water storage.

AGWRC HSPF parameter for the basic ground-water recession rate, the ratio of a given day's ground-water flow to the previous day's.

AUDRA The basin with the USGS streamflow-gaging station "Middle Fork River at Audra," station number 03052000, at the terminus.

BASETP HSPF parameter for the fraction of the remaining potential evapotranspiration that can be satisfied from base flow.

BASINS Better Assessment Science Integrating point and Nonpoint Sources.

BMP Best-management practices.

BOD Biochemical oxygen demand.

BRANDYWINE The basin with the USGS streamflow-gaging station "South Fork South Branch Potomac River at Brandywine," station number 01607500, at the terminus.

BUFFALO The basin with the USGS streamflow-gaging station "Buffalo Creek at Barrackville," station number 03061500, at the terminus.

CEPSC HSPF parameter for interception storage capacity.

CLEAR FORK The basin with the USGS streamflow-gaging station "Clear Fork at Clear Fork," station number 03202750, at the terminus.

CBP Chesapeake Bay Program.

CBPO Chesapeake Bay Program Office.

CBP/CWM Chesapeake Bay Program/Community Watershed Model.

CSNOFG HSPF parameter for indicating whether snow accumulation and melt are considered in the simulation.
DEEPFR HSPF parameter for the fraction of ground-water inflow that flows to inactive ground water.

DEM Digital elevation model.

DEVT Daily values of potential evapotranspiration.

DUNLOW The basin with the USGS streamflow-gaging station "East Fork Twelvepole Creek near Dunlow," station number 03206600, at the terminus.

ESRI Environmental Systems Research Institute.

ET Evapotranspiration.

EVAP Pan evaporation.

FOREST HSPF parameter indicating the fraction of the land segment covered by forest transpiring in winter.

GIS Geographic information system.

HSPF Hydrologic Simulation Program- FORTRAN.

HSPEXP Hydrological Simulation Program- FORTRAN EXPert system.

HWTFG HSPF parameter indicating whether a wetland (high water table) is prevalent on the land segment.

IFFCFG HSPF parameter indicating whether the effect of frozen ground on infiltration rate is considered in the simulation.

IMPLND Impervious land segment.

INFEXP HSPF parameter for the exponent in the infiltration equation.

INFILD HSPF parameter for the ratio between the maximum and mean infiltration capacities over the land segment.

INFILT HSPF parameter for an index to the infiltration capacity of the soil.

INTFW HSPF parameter for the interflow inflow.

IRC HSPF parameter for the interflow recession constant, ratio of a given day's interflow to the previous day's.

IRRGFG HSPF parameter selecting the method to determine demands in the irrigation module of the simulation.

KVARY HSPF parameter for indicating the behavior of the ground-water recession flow, enabling a non-exponential decay with time.

LOCKW00D The basin with the USGS streamflow-gaging station "Peters Creek near Lockwood," station number 03191500, at the terminus.

LSUR HSPF parameter for the length of the overland flow plane. 
LZETP HSPF parameter for lower zone evapotranspiration.

LZS HSPF parameter or state variable for the lower-zone storage quantity.

LZSN HSPF parameter for the nominal capacity of the lowerzone storage.

MIDVALE The basin with the USGS streamflow-gaging station "Middle Fork at Midvale," station number 03051500, at the terminus.

NAPD/NTN National Atmospheric Deposition Program/ National Trends Network.

NCDC/NDPT National Climatic Data Center/numeric data package.

NED National elevation dataset.

NHD National Hydrography Dataset.

NHDS National Oceanic and Atmospheric Administration Hydrologic Data Systems.

NLCD National Land Cover Data program.

NOAA National Oceanic and Atmospheric Administration.

NRAC Natural Resource Analysis Center.

NSUR HSPF parameter for Manning's roughness of the land surface.

NURP Nationwide Urban Runoff Project.

OSM Office of Surface Mining Reclamation and Enforcement.

PANTHER The basin with the USGS streamflow-gaging station "Panther Creek near Panther," station number 03213500, at the terminus.

PDRO HSPF parameter for potential direct runoff.

PERLND Pervious land segment.

PETMAX HSPF parameter for the air temperature below which evapotranspiration will be reduced if snow is simulated.

PETMIN HSPF parameter for the air temperature below which evapotranspiration will be forced to zero if snow is simulated.

PEVT Potential evapotranspiration.

PRMS Precipitation-Runoff Modeling System.

PWATER HSPF subroutine containing "tables" or groups of watershed parameters.

RCID Reedy Creek Improvement District.

RCHRES A stream reach.
RPARM HSPF parameter indicating the upper limit on how much of the evapotranspiration can be taken from the lower zone.

RTOPFG HSPF parameter for selecting the algorithm for computing overland flow for the simulation.

SLSUR HSPF parameter for slope of the overland flow plane.

SMCRA Surface Mining and Reclamation Act of 1977.

SNOWCF HSPF parameter for a snow gage catch correction factor.

USACE U.S. Army Corps of Engineers.

USEPA U.S. Environmental Protection Agency.

USGS U.S. Geological Survey.

UCI User control input.

UZFG HSPF parameter for selecting the method for computing inflow to the upper zone for the simulation.

UZS HSPF parameter or state variable for the upper-zone storage quantity.

UZSN HSPF parameter for the nominal capacity of the upperzone storage.

VAUGHAN The basin with the USGS streamflow-gaging station "Twentymile Creek at Vaughan," station number 03192200, at the terminus.

VCSFG HSPF parameter indicating whether interception storage capacity is considered in the simulation.

VIFWFG HSPF parameter indicating whether interflow inflow is considered in the simulation.

VIRCFG HSPF parameter indicating whether interflow recession constant is considered in the simulation.

VLEFG HSPF parameter indicating whether lower-zone evapotranspiration is considered in the simulation.

VNNFG HSPF parameter indicating whether Manning's roughness for the land surface is considered in the simulation.

VUZFG HSPF parameter indicating whether upper-zone nominal storage is considered in the simulation.

WCMS West Virginia Watershed Characterization and Modeling System.

WDM Water data management.

WMS Watershed modeling system.

WVDEP/DMR West Virginia Department of Environmental Protection, Division of Mining and Reclamation. 


\section{Appendix A: Modeling Theory in Hydrologic Simulation Program-FORTRAN Model (HSPF)}

Hydrologic Simulation Program-FORTRAN (HSPF) is a comprehensive watershed model, but one can get a sense of how it works by considering what happens in a pervious land segment (PERLND). A PERLND is a land-segment subdivision of the simulated watershed where infiltration is possible. The following vertical-moisture sequence atmosphere, vegetation, snow zone, surface zone, overland flow plane, upper soil zone, lower soil zone, active ground-water zone, and deep or inactive ground-water zone is shown in detail in fig. A-1. The shaded area is below the surface of the land. Evapotranspiration moves to the left and up; numbers on the left indicate the order that evaporation is taken from the PERLND. Runoff moves to the right.

\section{Interception}

Interception storage is water retained by any and all storage above the overland flow plane. Interception does not run off or infiltrate; any moisture that does not exceed the interception capacity is evaporated. Interception is one of five sources that make up the total evapotransportation (ET) for a given land segment. Only the sum of the evapotranspiration limits how much of the available moisture in interception storage can be evaporated; there is no rate limit. None of the precipitation can infiltrate or run off until the interception storage capacity (CEPSC) is exceeded.

\section{$\underline{\text { HSPF PERLND Module }}$}

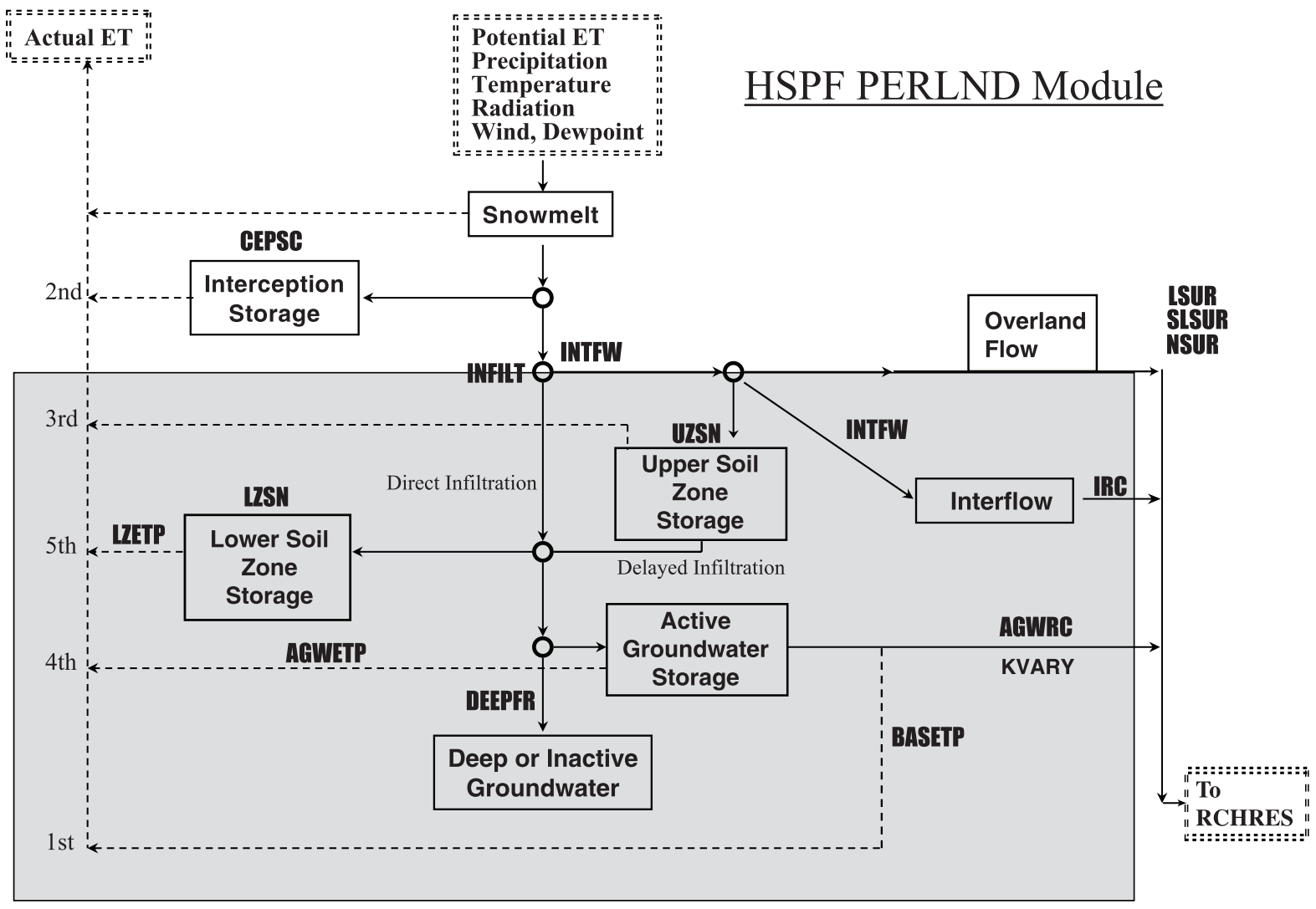

Figure A-1. Processes simulated in the Hydrologic Simulation Program-FORTRAN Model (HSPF) pervious land segment (PERLND) module. The shaded area depicts processes beneath land surface. [CEPSC, interception storage capacity; LSUR, length of the overland flow plane; SLSUR, slope of the overland flow plane; NSUR, Manning's roughness of the land surface; INTFW, interflow inflow; INFILT, index to the infiltration capacity of the soil; UZSN, nominal capacity of the upper-zone storage; IRC, interflow recession constant; LZSN, nominal capacity of the lower-zone storage; LZETP, lower-zone evapotranspiration; AGWRC, basic ground-water recession rate; AGWETP, fraction of remaining potential evapotranspiration that can be satisfied from active ground-water storage; KVARY, indication of the behavior of groundwater recession flow; DEEPFR, fraction of ground-water inflow that flows to inactive ground water; BASETP, fraction of the remaining potential evapotranspiration that can be satisfied from base flow (from a lecture by Kate Flynn,

U.S. Geological Survey, written commun., 2004)] 


\section{Division on the Overland Flow Plane}

When the interception storage is full, precipitation is routed directly to the land surface. Once on the land surface, precipitation may infiltrate, remain in surface detention storage, or run off directly to the river channel.

Infiltration is restricted by low values of a rate parameter, INFILT. Infiltration also is a function of the instantaneous soil-moisture profile. Standard values are usually given to two other parameters: INFILD, a parameter for the ratio between maximum and mean infiltration capacities over the land segment, and INFEXP, a parameter for the exponent in the infiltration equation (Bicknell and others, 2001).

The moisture that cannot directly infiltrate becomes potential direct runoff (PDRO). PDRO is divided into two parts: potential surface detention/runoff and potential interflow inflow. Flux to upper-zone storage (UZI, upper zone inflow) is the first moisture taken from PDRO. For this study (and $\mathrm{CBP}$ ), the fraction of PDRO that flows into upper-zone storage is computed directly as a function of the soil-moisture profile (the ratio of upper-zone storage to lower-zone storage). A division between potential surface detention/runoff (PSUR) and UZI + potential interflow inflow is determined by a function that considers infiltration, soil conditions, and the parameter INTFW (interflow inflow). A division between surface detention and surface runoff is determined by use of the ChezyManning equation (Chow, 1964) and an empirical expression that relates outflow depth to detention storage (Bicknell and others, 2001).

\section{Beneath the Land Surface}

Interflow.- Interflow drains more rapidly with decreasing values of a recession-rate parameter, IRC (fraction of yesterday's interflow). Moisture that remains will occupy interflow storage. Interflow storage is short lived and is not a source from which the sum of the evapotranspiration is totaled for a land segment.

Upper soil zone storage.- From the upper soil zone, moisture can be lost either through evapotranspiration to the atmosphere or percolation to any lower layer. Moisture evaporates from the upper zone only when it is wet, as indicated by a ratio of upper zone storage to nominal capacity (UZS/ UZSN) that is greater than 2.0. Percolation is simulated using the same INFILT parameter (an index to the infiltration capacity of the soil) that was used at the land surface in a different equation that empirically accounts for the behavior of the upper soil zone.

Lower soil zone storage.- Direct infiltration and percolation are the usual sources of moisture to the lower soil zone. The inflowing fraction of that moisture is determined empirically as a function of soil moisture in the lower zone. Water stored in the lower zone is removed only through evapotranspiration. All influences on the evapotranspiration opportunity are lumped into the LZETP parameter. LZETP is used to calculate RPARM, an upper limit on how much of the evapotranspiration can be taken from the lower zone in the present interval. RPARM also is a function of the current relative moisture content in the lower zone (LZS, a parameter for the lower zone storage/LZSN, a parameter for the nominal capacity of the lower zone storage), and evaprotranspiration decreases as the lower zone dries.

Active ground-water storage.- The fraction of the moisture supply remaining after the surface, upper zone, and lower zone components are subtracted further infiltrates to active and inactive ground-water storage. For active ground-water storage, the parameter AGWETP is the fraction of the remaining potential evapotranspiration that can be satisfied from the active ground-water storage. If the value of AGWETP is zero, all moisture that enters the active ground-water zone eventually discharges to the stream as base flow. Ground-water discharge is computed as a function of active ground-water storage by means of two parameters: AGWRC, a parameter for the basic ground-water recession rate, and KVARY, a parameter for indicating the behavior of the ground-water recession flow, enabling a non-exponential decay with time. Additionally, ground-water discharge to the stream may be reduced through evapotranspiration by riparian lands and vegetation. This reduction feature is controlled by setting the value of BASETP. BASETP is the fraction per interval (a rate) of remaining potential evapotranspiration that can be satisfied from groundwater outflow or base flow, if enough is available.

Deep or inactive ground water.- The distribution to active and inactive ground water is user designated by the parameter DEEPFR, that fraction of ground-water inflow that flows to inactive ground water. Inactive ground water is not a source from which the sum of the evapotranspiration is totaled for a land segment, and once ground water is inactive, it cannot affect streamflow.

\section{References in appendix A}

Bicknell, B.R., Imhoff, J.C., Kittle, J.L., Jr., Jobes, T.H., and Donigian, A.S., Jr., 2001, HSPF Version 12 User's Manual: Mountain View, Calif., AQUA TERRA Consultants, 845 p.

Chow, V.T., ed., 1964, Handbook of applied hydrology: New York, McGraw-Hill, p. 7-24. 


\section{Appendix B: Digital-Spatial Data Used for Initial User Control Input (UCI) File Creation}

In all cases, initial user control input (UCI) files and Hydrologic Simulation Program-FORTRAN (HSPF) simulations were generated by means of a multipurpose geographic information system (GIS) environmental and ecological analysis system called Better Assessment Science Integrating Point and Nonpoint Sources (BASINS, Lahlou and others, 1998) developed by USEPA. The BASINS version used in this study, BASINS 3.0, is a GIS application using software from the Environmental Systems Research Institute, Inc. (ESRI); specifically, ArcView GIS 3.3 (ESRI, May 29, 2002). BASINS is considered the most cost-effective means of bringing together GIS data and national watershed-related data to produce HSPF model framework.

BASINS 3.0 Web extractor extension was used to create the initial BASINS projects for the eight basins identified by a streamflow-gaging station at the terminus, and the BASINS projects were organized by cataloging-unit number (11-digit watersheds). For each station, the basin to be simulated was delineated by automated methods in BASINS and the West Virginia Watershed Characterization and Modeling System (WCMS), using a Digital Elevation Model (DEM) based on 20-meter DEM grid cells. Sources (runoff-producing portions of the DEM) and sinks (runoff-receiving portions of the DEM) were eliminated, and stream centerlines from the National Hydrography Dataset (NHD) were burned into the DEM. The original source of the DEM data was the National Elevation Dataset (NED), a seamless raster product produced by the USGS (http://gisdata.usgs.net/NED). The Natural Resource Analysis Center (NRAC) smoothed the DEM and burned in the streams (Mike Strager, Natural Resource Analysis Center, oral commun., 2002).

For each streamflow-gaging station, the basin and subbasins were automatically delineated by use of a slightly expanded boundary as a mask over the statewide DEM. This technique ensures that the automated basin and subbasin delineation routine within BASINS will consider all contributing area within the entire drainage. A minimum threshold area was determined for each basin such that 8-15 subbasins would be delineated; additional subbasins were added where slope and land use changed, and where major tributaries intersected. LOCKWOOD and VAUGHAN were not correctly delineated near the downstream boundaries by the automated methods. Therefore, boundaries for these stations were manually delineated before subbasins could be correctly delineated by automated methods.

The land-use/land-cover data are a simplified 30-m grid from the USGS/USEPA National Land Cover Data program (NLCD). These data originated with LANDSAT images of the early 1990s for West Virginia. The data were generalized for this project from 21 to 9 classifications (Mike Strager, Resource Analysis Center, oral commun., 2003). The agri- cultural classifications were combined into one; the forested classifications were combined into two; the wetland classifications were combined into one; and, the urban classifications were combined into one. Coal-mine-permit areas from the mid-1980s to 2002 were added to the remaining nine classifications, making a total of 10 classifications used in this study: hardwood forest, shrubland, pasture/grassland, row-crop agriculture, urban/developed, barren land, wetland, mined land, surface water, and conifer forest.

An estimated percentage of each land-use/land-cover classification that was permeable was used to create the initial UCI file. Seventy percent of the urban/developed lands were estimated as permeable by assuming that most developed lands for this study are actually low-intensity residential areas. Ninety percent of barren lands were estimated as permeable by assuming that occasional heavy rainfall that is prevalent in summer can rapidly saturate the surface. Seventy percent of mined lands were estimated as permeable by assuming that (1) surface mined area is first cleared to barren ground before mining begins, and (2) some mining techniques produce a pavement-like surface during active mining. All the land surface of the remaining land-use/land-cover classifications was estimated as permeable.

\section{Summary of Digital Spatial Data for the Eight Study Basins}

AUDRA.- The drainage area of the AUDRA Basin was computed as $149.3 \mathrm{mi}^{2}$ by automated methods, stored as $149.50 \mathrm{mi}^{2}$ in the UCI file (the minor difference is due to rounding to integer acres), and reported as $148 \mathrm{mi}^{2}$ by the U.S. Geological Survey (USGS) in table 1. The threshold area used to generate 12 subbasins was 2,000 hectares. The land use/land cover for AUDRA was 88-percent hardwood forest, 10-percent pasture/grassland, and less than 2-percent of all other land-use/land-cover classifications.

BUFFALO.- The drainage area of the BUFFALO Basin was computed as $115.9 \mathrm{mi}^{2}$ by automated methods, stored as $115.85 \mathrm{mi}^{2}$ in the UCI file, and reported as $116 \mathrm{mi}^{2}$ by the USGS in table 1 . The threshold area used to generate 10 subbasins was 2,000 hectares. The land use/land cover for BUFFALO was 80- percent hardwood forest, 14-percent pasture/ grassland, 2-percent shrubland, 2-percent urban/developed, 1-percent mined, and less than 1-percent of all other land-use/ land-cover classifications.

CLEAR FORK.- The drainage area of the CLEAR FORK Basin was computed as $126.3 \mathrm{mi}^{2}$ by automated methods, stored as $126.25 \mathrm{mi}^{2}$ in the UCI file, and reported as 126 $\mathrm{mi}^{2}$ by the USGS in table 1 . The threshold area used to generate 21 subbasins was 800 hectares. The land use/land cover for CLEAR FORK was 89-percent hardwood forest, 5-percent 
mined, 2-percent pasture/grassland, 1-percent urban/developed, 1-percent shrubland, and less than 2-percent of all other land-use/land-cover classifications.

DUNLOW. - The drainage area of the DUNLOW Basin was computed as $37.7 \mathrm{mi}^{2}$ by automated methods, stored as $37.73 \mathrm{mi}^{2}$ in the UCI file, and reported as $38.5 \mathrm{mi}^{2}$ by the USGS in table 1 . The threshold area used to generate 10 subbasins was 500 hectares. The land use/land cover for DUNLOW was 86-percent hardwood forest, 11-percent mined, 2-percent pasture/grassland, and less than 1-percent of all other land-use/land-cover classifications. The classification of coal-mine-permit areas from the mid-1980s to 2002 postdates the calibration period used for DUNLOW.

LOCKWOOD. - The drainage area of the LOCKWOOD Basin was computed as $40.2 \mathrm{mi}^{2}$ by automated methods, stored as $40.21 \mathrm{mi}^{2}$ in the UCI file, and reported as $40.2 \mathrm{mi}^{2}$ by the USGS in table 1 . The threshold area used to generate 16 subbasins was 500 hectares. The land use/land cover for LOCKWOOD was 82-percent hardwood forest, 8-percent mined, 8percent pasture/grassland, 1-percent urban/developed, and less than 1-percent of all other land-use/land-cover classifications.

MIDVALE. - The drainage area of the MIDVALE Basin was computed as $123.4 \mathrm{mi}^{2}$ by automated methods, stored as $123.37 \mathrm{mi}^{2}$ in the UCI file, and reported as $122 \mathrm{mi}^{2}$ by the USGS in table 1 . The threshold area used to generate 12 subbasins was 2,000 hectares. The land use/land cover for MIDVALE was 90-percent hardwood forest, 9-percent pasture/ grassland, and less than 1-percent of all other land-use/landcover classifications.

PANTHER. - The drainage area of the PANTHER Basin was computed as $30.1 \mathrm{mi}^{2}$ by automated methods, stored as $30.16 \mathrm{mi}^{2}$ in the UCI file, and reported as $30.8 \mathrm{mi}^{2}$ by the USGS in table 1 . The drainage areas are within 2.1 percent, which was considered acceptable for this study. The threshold area used to generate 11 subbasins was 400 hectares. The land use/land cover for PANTHER was 99-percent hardwood forest and less than 1-percent of all other land-use/land-cover classifications.

VAUGHAN. - The drainage area of the VAUGHAN Basin was computed as $45.2 \mathrm{mi}^{2}$ by automated methods, stored as $45.28 \mathrm{mi}^{2}$ in the UCI file, and reported as $46.2 \mathrm{mi}^{2}$ by the USGS in table 1 . The threshold area used to generate 14 subbasins was 500 hectares. The land use/land cover for VAUGHAN was 72-percent hardwood forest, 27-percent mined, 1-percent barren, and less than 1-percent of all other land-use/land-cover classifications.

\section{References in appendix B}

ESRI, 2002, ArcView 3.3 Now available, May 29, 2002, Press Release: Redlands, Calif., Environmental Systems Research Institute, Inc., accessed July 27, 2004, at

http://www.esri.com/news/releases/02_2qtr/arcview33.html
Lahlou, M., Shoemaker, L., Choudhury, S., Elmer, R., Hu, A., Manguerra, H., and Parker, A., 1998, BASINS-Better Assessment Science Integrating Nonpoint and point Source, user's manual, version 2.0: Fairfax, Va., U.S. Environmental Protection Agency, EPA-823-B-98-006, 360 p. 


\section{Appendix C: Time-Series Data Used for Initial Water Data Management (WDM) File Creation}

Input time-series data, primarily from precipitation and evaporation/evapotranspiration, drive an Hydrologic Simulation Program-FORTRAN (HSPF) simulation. The sources of precipitation data are summarized in table $\mathrm{C}-1$, and the seasonal and annual values of precipitation and evaporation/ evapotranspiration are summarized in table $\mathrm{C}-2$.

\section{Sources of Precipitation Data}

Precipitation is the primary forcing function to watershed simulations. The Natural Resource Analysis Center (NRAC) provided most of the precipitation time-series data used in this study (Jerry Fletcher, Ph.D., Natural Resource Analysis

Table C-1. Sources of precipitation and evaporation/evapotranspiration time series for the eight study basins in West Virginia, and the Brandywine Basin in West Virginia and Virginia, used in this study.

[DSN, dataset number; WDM, water data management file; CBP/CWM, Chesapeake Bay Program/Community Watershed Model; NRAC, Natural Resource Analysis Center; USEPA, U.S. Environmental Protection Agency; BASINS, Better Assessment Science Integrating Point and Nonpoint Sources; NHDS, National Oceanic and Atmospheric Administration Hydrologic Data Systems; NCDC/NDP, National Climatic Data Center/Numeric Data Package]

\begin{tabular}{|c|c|c|c|c|}
\hline \multirow{2}{*}{$\begin{array}{l}\text { Basin name } \\
\text { (Fig. 1) }\end{array}$} & \multicolumn{2}{|r|}{ Precipitation } & \multicolumn{2}{|r|}{ Evaporation } \\
\hline & $\begin{array}{c}\text { DSN } \\
\text { in } \\
\text { WDM }\end{array}$ & Source & $\begin{array}{c}\text { DSN } \\
\text { in } \\
\text { WDM }\end{array}$ & Source \\
\hline \multirow{2}{*}{ BRANDYWINE } & 702 & From CBP/CWM, Phase 3 & 40 & \multirow{2}{*}{$\begin{array}{l}\text { From } \mathrm{CBP} / \mathrm{CWM} \\
\text { From } \mathrm{CBP} / \mathrm{CWM} \text { (extended the time } \\
\quad \text { series from Phase } 3 \text { ) }\end{array}$} \\
\hline & 1170 & From CBP/CWM, Phase 4 & 40 & \\
\hline \multirow{2}{*}{ AUDRA } & \multirow{2}{*}{70} & \multirow{2}{*}{$\begin{array}{l}\text { NRAC supplied hourly rainfall } \\
\text { focused on "Elkins" }\end{array}$} & 56 & \multirow{2}{*}{$\begin{array}{l}\text { Site "Elkins WSO Airport" in wv.wdm } \\
\text { from USEPA BASINS }\end{array}$} \\
\hline & & & 52 & \\
\hline \multirow{2}{*}{ BUFFALO } & \multirow{2}{*}{327} & \multirow{2}{*}{$\begin{array}{l}\text { NRAC supplied hourly rainfall } \\
\text { focused on "Barrackville" }\end{array}$} & 316 & \multirow{2}{*}{$\begin{array}{l}\text { Site "Lake Lynn" in wv.wdm (renum- } \\
\text { bered) from USEPA BASINS }\end{array}$} \\
\hline & & & 312 & \\
\hline \multirow{2}{*}{ CLEAR FORK } & \multirow{2}{*}{3011} & \multirow{2}{*}{$\begin{array}{l}\text { NRAC supplied hourly rainfall } \\
\text { focused on "Clear Fork" (Wyo- } \\
\text { ming County) }\end{array}$} & 16 & \multirow{2}{*}{$\begin{array}{l}\text { Site "Beckley WSO AP" in wv.wdm } \\
\text { from USEPA BASINS }\end{array}$} \\
\hline & & & 12 & \\
\hline DUNLOW & 33 & $\begin{array}{l}\text { NRAC supplied hourly rainfall } \\
\text { focused on "Dunlow" }\end{array}$ & 5203 & $\begin{array}{l}\text { Generated from temperature from sites } \\
\text { "Gary" patched }{ }^{1} \text { with "Logan" from } \\
\text { NHDS }\end{array}$ \\
\hline LOCKWOOD & 56 & $\begin{array}{l}\text { Site "London Locks" (disaggre- } \\
\text { gated }^{2} \text { and smoothed }{ }^{3} \text { ) from } \\
\text { NHDS }\end{array}$ & 64 & $\begin{array}{l}\text { Generated from temperature from } \\
\text { sites "London Locks" patched }{ }^{1} \text { with } \\
\text { "Gary" patched with "Logan" from } \\
\text { NHDS }\end{array}$ \\
\hline MIDVALE & 58 & $\begin{array}{l}\text { Sites "Buckhannon" patched }{ }^{1} \\
\text { with "Glenville } 1 \text { ENE" (disag- } \\
\text { gregated }{ }^{1} \text { and smoothed }{ }^{3} \text { ) from } \\
\text { NHDS }\end{array}$ & 20 & $\begin{array}{l}\text { Generated from temperature from sites } \\
\text { "Buchannon" patched }{ }^{1} \text { with "Glen- } \\
\text { ville" from NCDC/NDP }\end{array}$ \\
\hline \multirow{2}{*}{ PANTHER } & \multirow{2}{*}{247} & \multirow{2}{*}{$\begin{array}{l}\text { NRAC supplied hourly rainfall } \\
\text { focused on "Dunlow" (about } \\
46 \text { miles away) }\end{array}$} & 236 & \multirow{2}{*}{$\begin{array}{l}\text { Site "Hurley" in va.wdm from USEPA } \\
\text { BASINS }\end{array}$} \\
\hline & & & 232 & \\
\hline VAUGHAN & 56 & $\begin{array}{l}\text { Site "London Locks" (disaggre- } \\
\text { gated }^{2} \text { and smoothed }{ }^{3} \text { ) from } \\
\text { NHDS }\end{array}$ & 64 & $\begin{array}{l}\text { Generated from temperature from } \\
\text { sites "London Locks" patched }{ }^{1} \text { with } \\
\text { "Gary" patched with "Logan" from } \\
\text { NHDS }\end{array}$ \\
\hline
\end{tabular}




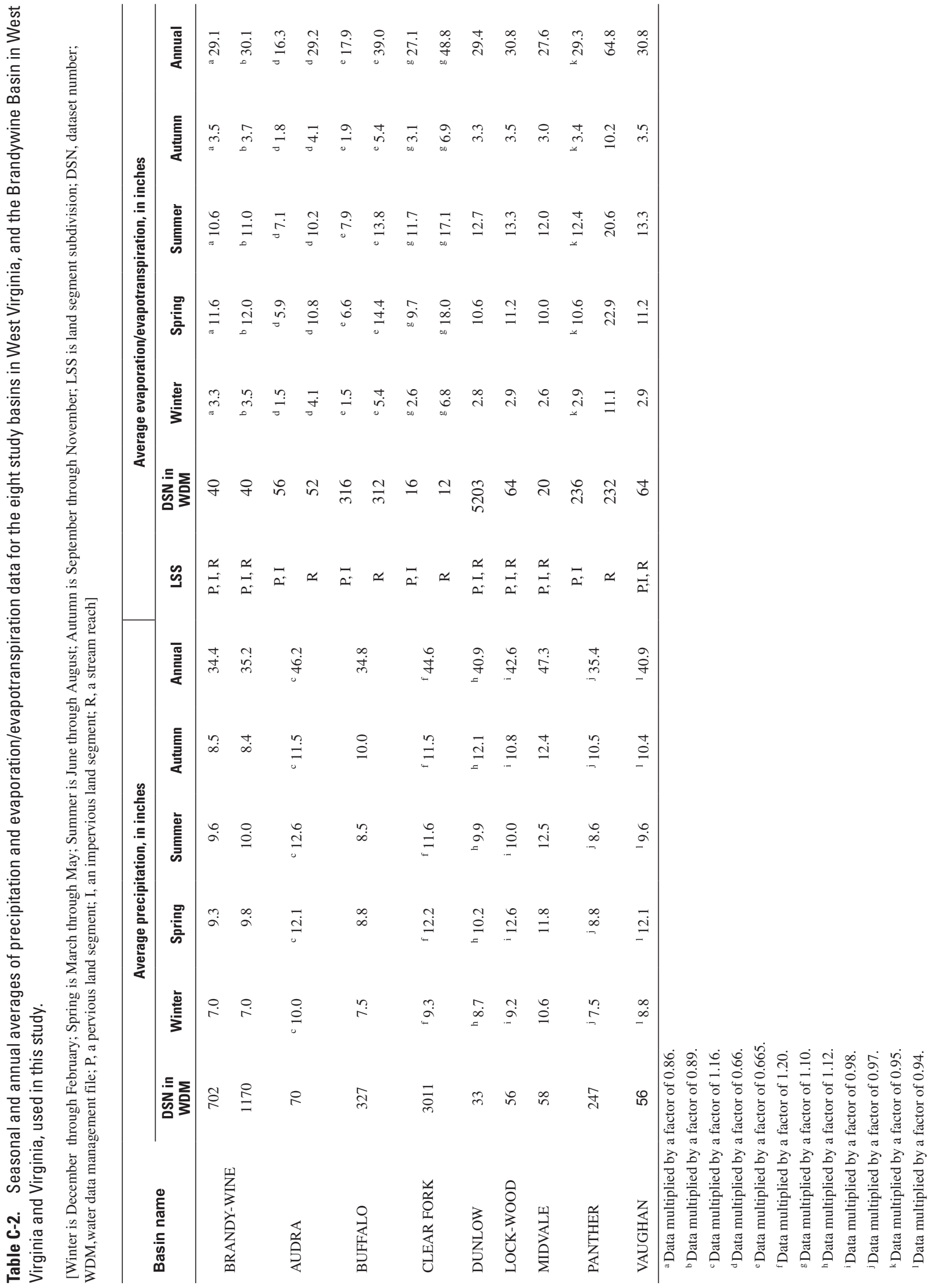


Center, written commun., December, 2003). In order to use precipitation data that would be adequate and advantageous for any basin of interest throughout the West Virginia coal fields, NRAC relied on a precipitation database and software from ZedX, Inc. of Bellefonte, Pa. The precipitation datasets for the AUDRA, BUFFALO, CLEAR FORK, DUNLOW, and PANTHER study basins (table C-2) were provided by NRAC.

Precipitation data from any of three other sources, described below, were acquired when data were not available from NRAC. Daily precipitation data were disaggregated to hourly time-series data by methods incorporated into the WDMUtil software (Hummel and Gray, 2001) when hourly data were not available. Precipitation data used by the Modeling Subcommittee of the Chesapeake Bay Program (CBP) for the U.S. Environmental Protection Agency (USEPA) Chesapeake Bay Program Office (CBPO), Annapolis, Maryland (http://www.chesapeakebay.net, accessed July 16, 2004) were used for guidance in rainfall disaggregation. CBPO developed methods for correlating, averaging, estimating missing values, and testing precipitation for 147 stations at the terminus of basins contributing to the Chesapeake Bay (Wang and others, 1997). CBPO used a Thiessen polygon network for areal weighting of observations and computed time series. Disaggregated time-series precipitation data were compared to precipitation intensities determined by CBPO for the USGS station 01607500, South Fork of the South Branch Potomac River at Brandywine (BRANDYWINE). A 4-hour smoothing process of disaggregated data was necessary to produce similar rainfall intensities. (See "Calibration and Verification of the Streamflow Simulations" section of this report for further discussion of this calibration process).

BASINS. - USEPA provides the Better Assessment Science Integrating Point and Nonpoint Sources (BASINS) software, which is downloadable from http:/www.epa.gov/ waterscience/basins/ (accessed July 16, 2004). USEPA also facilitates HSPF model runs by providing hourly precipitation time-series data from http:/www.epa.gov/waterscience/ftp/ basins/wdm_data/ (accessed July 16, 2004) in pre-made Water Data Management (WDM) files. In the BASINS directory structure, these WDM files are stored in \BASINS\DATA MET_DATA and are named by State.

NCDC/NDP. - The National Climatic Data Center (NCDC) Numeric Data Package (NDP) from the National Oceanic and Atmospheric Administration (NOAA) is perhaps the earliest (1871-1997) daily precipitation time-series data freely available on the Internet, at ftp://cdiac.esd.ornl.gov/pub/ $n d p 070 /$ (West Virginia is State 46 at NCDC). This source of observed, daily precipitation data was used to disaggregate hourly time-series data for HSPF simulations at MIDVALE.

NHDS. - The NOAA National Hydrologic Data Systems (NHDS) Group provides historical data at http://dipper.nws. noaa.gov/hdsb/data/archived/. This source of observed, daily precipitation data was used to disaggregate hourly time-series data for HSPF simulations at LOCKWOOD and VAUGHAN.

\section{Sources of Evaporation Data and Generated Evaporation/Evapotranspiration Time-Series Data}

Evaporation time-series data are of two types: pan evaporation observations including estimated pan evaporation (EVAP) and observed or estimated potential evapotranspiration (PEVT). A pan coefficient (0.7; see Farnsworth and others, 1982) could be multiplied by EVAP time-series data to calculate PEVT time-series data. EVAP and PEVT can be estimated separately. Lahlou and others (1998) describe the derivation of the four pregenerated EVAP and PEVT timeseries datasets used in this study. The remaining PEVT timeseries data were generated as described below.

In the process of building a User Control Input (UCI) file for a specific HSPF simulation, the WinHSPF computer program in BASINS applies PEVT time-series data to Pervious Land Segments (PERLNDs) and Impervious Land Segments (IMPLNDs). WinHSPF applies EVAP time-series data to water surfaces of stream reach/reservoir segments (RCHRESs) of the stream network; but, PEVT time-series data are applied to all land uses, including "surface water." This distinction is seldom necessary because the proportion a drainage area in RCHRESs is usually small. In this study, the EVAP/ PEVT distinction was dispensed with for DUNLOW, LOCKWOOD, MIDVALE, and VAUGHAN. The Chesapeake Bay Program Community Watershead Model (CBP/CWM) also dispensed with this distinction for BRANDYWINE, using the equivalent method of an EVAP time-series data with a coefficient, as described above.

Four sources of evaporation time-series data are referenced to this report: (1) data available through BASINS that have been pregenerated and preloaded in WDM files, (2) Hamon Potential Evapotranspiration (the same PEVT) data that were generated for this study by use of NCDC/NDP or NHDS temperature data, (3) NHDS downloadable daily observations of pan evaporation, and (4) CBP/CWM data for BRANDYWINE, both Phase 3 and Phase 4 simulations. The Penman method was used to generate the CBP/CWM EVAP (Wang and others, 1997). The Hamon method generates daily potential evapotranspiration (inches) by use of air temperature, a monthly variable coefficient, the number of hours of sunshine (computed from latitude), and absolute humidity (computed from air temperature). The Hamon and Penman methods are explained in the WDMUtil computer program manual (Hummel and Gray, 2001). 


\section{References in appendix C}

Hummel, J.K., Jr., and Gray, M., 2001, WDMUtil Version 2.0-A tool for managing watershed modeling time-series data, User's Manual: Decatur, Ga., AQUA TERRA Consultants, $157 \mathrm{p}$.

Lahlou, M., Shoemaker, L., Choudhury, S., Elmer, R., Hu, A., Manguerra, H., and Parker, A., 1998, BASINS—Better Assessment Science Integrating Nonpoint and point Source, user's manual, version 2.0: Fairfax, Va., U.S. Environmental Protection Agency, EPA-823-B-98-006, 360 p.
Wang, P., Storrick, J., and Linker, L.C., 1997, Chesapeake Bay Watershed model application and calculations of nutrient and sediment loadings, Appendix D-Phase IV Chesapeake Bay Watershed model precipitation and meteorological data development and atmospheric nutrient deposition report of the Modeling Subcommittee, August, 1997: Annapolis, Md., 58 p., accessed July 16, 2004, at http://www.chesapeakebay.net/pubs/112.pdf

\section{Appendix D: Statistical Limits of Calibration Criteria}

Table D-1. Statistical limits of calibration criteria (modified from Lumb and others, 1994) used in this study.

\begin{tabular}{|c|c|c|}
\hline $\begin{array}{l}\text { Criteria identifica- } \\
\text { tion number }\end{array}$ & Description of calibration criteria & Statistical limit \\
\hline E1 & Maximum error in the total runoff volume & \pm 10.0 percent \\
\hline E2 & $\begin{array}{l}\text { Maximum error in low-flow recession (an average of a given day's } \\
\text { streamflow divided by the previous day's streamflow for stream- } \\
\text { flows between the 50- and 100-percent flow durations) }\end{array}$ & \pm 0.01 day $^{-1}$ \\
\hline E3 & Maximum error in the 50-percent lowest runoff total & \pm 10.0 percent \\
\hline E4 & Maximum error in the 10-percent highest runoff total & \pm 15.0 percent \\
\hline E5 & Maximum error in the average of peak-storm runoff volumes & +15.0 percent \\
\hline E6 & $\begin{array}{l}\text { Minimum total interflow as a multiple of total surface runoff } \\
\text { or 1/E6 is the maximum total surface runoff as a fraction of total } \\
\text { interflow }\end{array}$ & 2.5 (dimensionless) \\
\hline E7 & $\begin{array}{l}\text { Maximum of summer percentage error of runoff volume minus winter } \\
\text { percentage error of runoff volume }\end{array}$ & \pm 10.0 percent \\
\hline E8 & Maximum error of summer storm volume & \pm 15.0 percent \\
\hline E9 & $\begin{array}{l}\text { Multiplier for E3 and E4, used to compute the error term for the vol- } \\
\text { ume rule for INFILT (the infiltration parameter, in inches per day) } \\
\text { and is a multiplier on the error term that is used for the low-flow rule } \\
\text { for INFILT }\end{array}$ & 1.5 (dimensionless) \\
\hline E10 & Maximum percent of time in base flow & +30.0 percent \\
\hline
\end{tabular}

\section{References in appendix D}

Lumb, A.M., McCammon, R.B., and Kittle, J.L., Jr., 1994, Users manual for an Expert System (HSPEXP) for calibration of the Hydrological Simulation Program-Fortran: U.S. Geological Survey Water-Resources Investigations Report94-4168, 102 p. 


\section{Appendix E: Part of the Output from the Expert System for the Calibration of the Hydrological Simulation Program - FORTRAN (HSPEXP) Computer Program Showing Calibration Statistics for AUDRA (January 1, 1990, through September 30, 1979)}

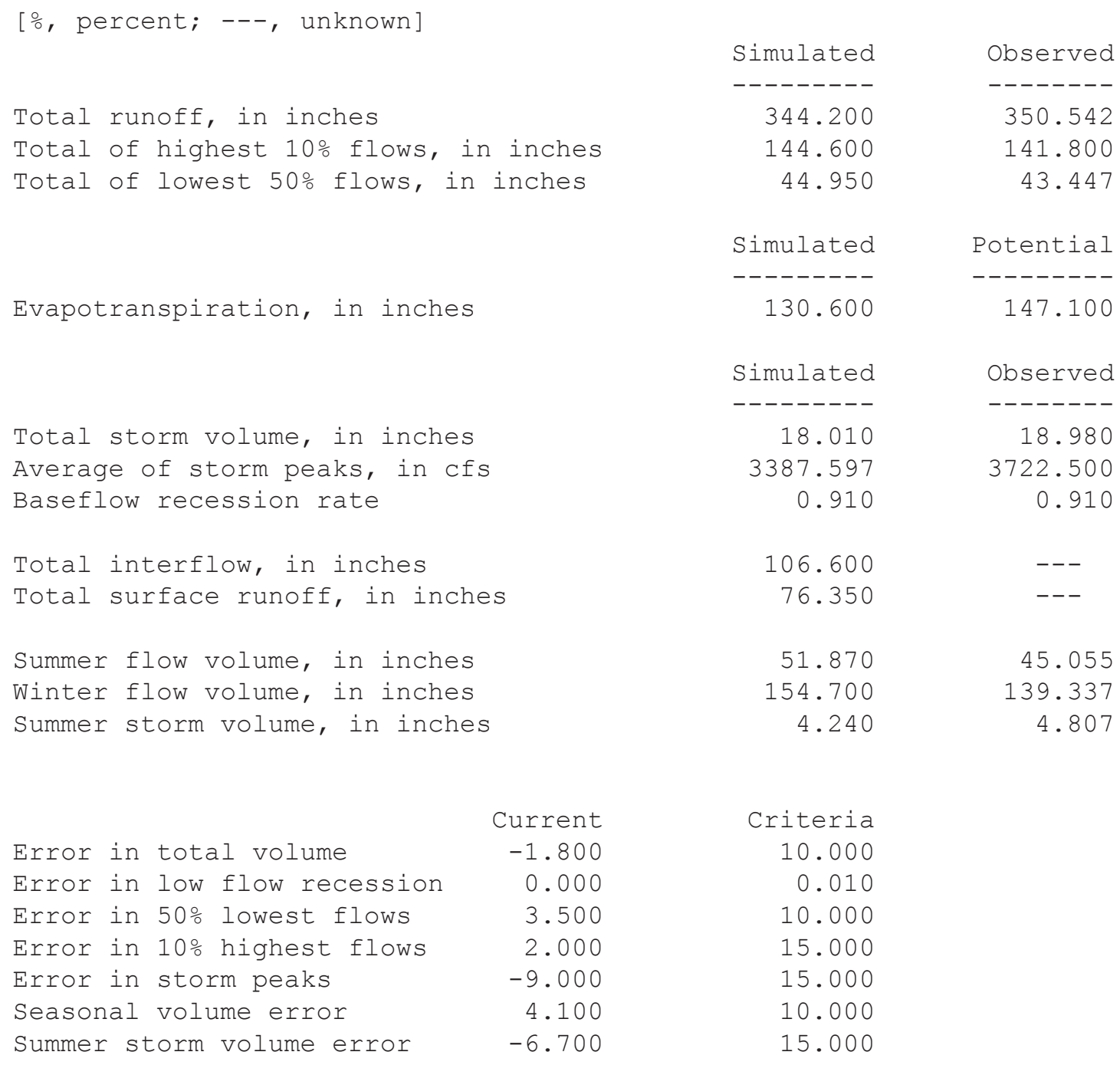

Simulated

Total runoff, in inches

Total of highest 10\% flows, in inches

Total of lowest 50\% flows, in inches

Evapotranspiration, in inches

Total storm volume, in inches

Average of storm peaks, in cfs

Baseflow recession rate

Total interflow, in inches

Total surface runoff, in inches

Summer flow volume, in inches

Winter flow volume, in inches

summer storm volume, in inches

$\begin{array}{rr}\text { Current } & \text { Criteria } \\ -1.800 & 10.000 \\ 0.000 & 0.010 \\ 3.500 & 10.000 \\ 2.000 & 15.000 \\ -9.000 & 15.000 \\ 4.100 & 10.000 \\ -6.700 & 15.000\end{array}$

Error in total volume

Error in low flow recession

Error in 50\% lowest flows

Error in 10\% highest flows

Error in storm peaks

Seasonal volume error

Summer storm volume error

0.597

0.910

4.240

15.000 


\section{Appendix F: Part of the Output from the Expert System for the Calibration of the Hydrological Simulation Program - FORTRAN (HSPEXP) Computer Program Showing Calibration Statistics for BUFFALO (January 1, 1970, through December 31, 1980)}

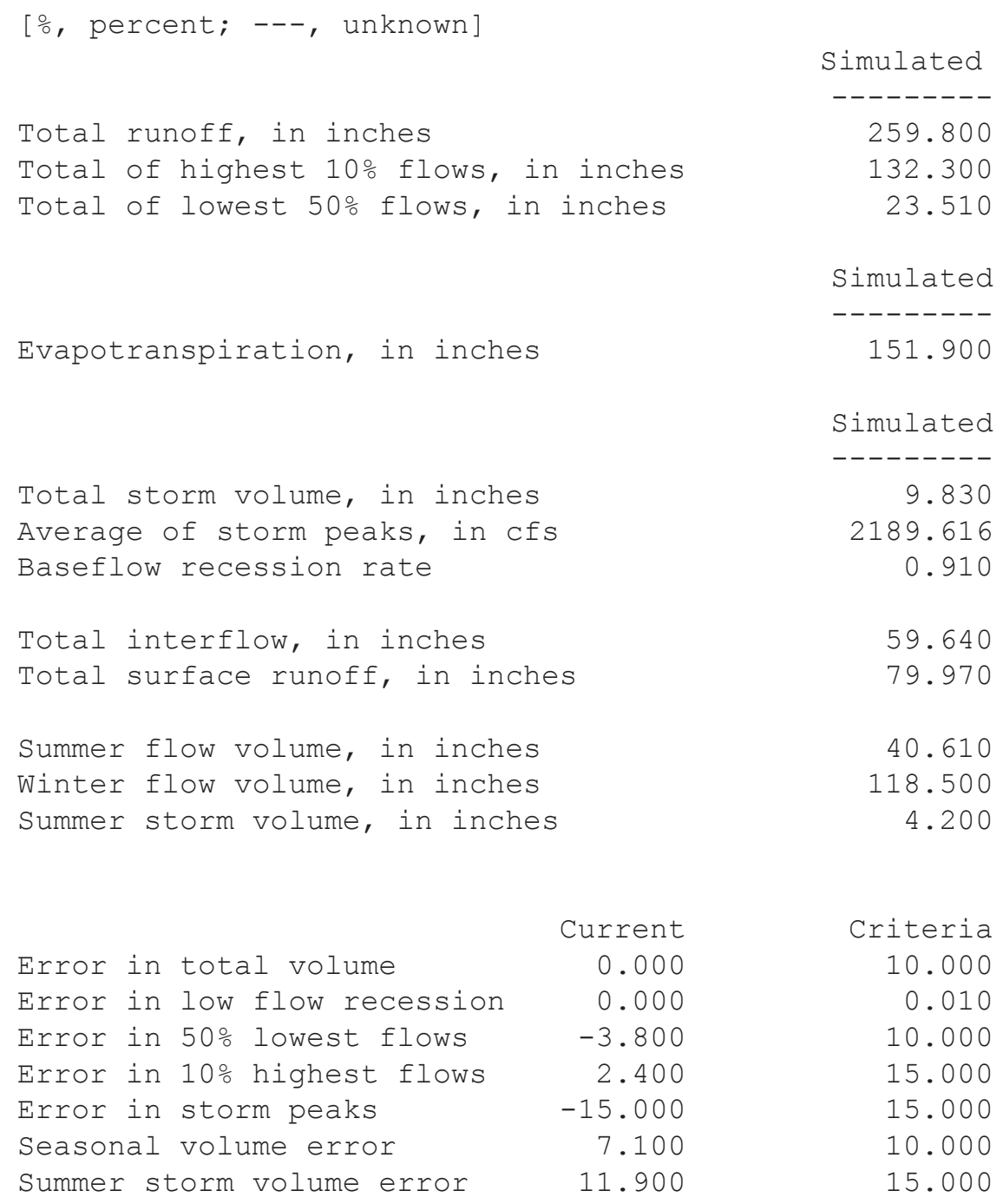

Simulated

Total runoff, in inches

Total of highest $10 \%$ flows, in inches

Total of lowest 50\% flows, in inches

Evapotranspiration, in inches

Total storm volume, in inches

Average of storm peaks, in cfs

Baseflow recession rate

Total interflow, in inches

Total surface runoff, in inches

Summer flow volume, in inches

Winter flow volume, in inches

Summer storm volume, in inches

Current

0.000

0.000

$-3.800$

2.400

$-15.000$

7.100

11.900

Simulated

151.900

Simulated

9.830

2189.616

0.910

59.640

79.970

40.610

118.500

4.200

Criteria 10.000

0.010

10.000

15.000

15.000

10.000

15.000

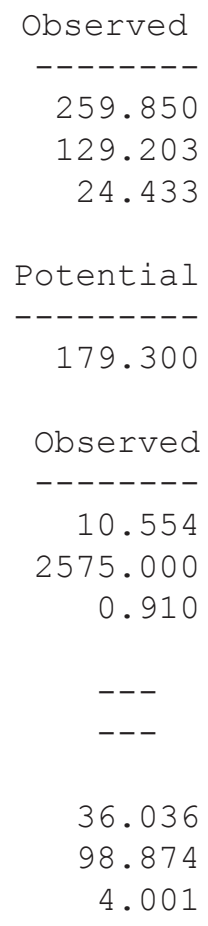

Observed

--------

259.850

129.203

24.433

Potential

179.300

Observed

10.554

2575.000

0.910

36.036

98.874

4.001 


\section{Appendix G: Part of the Output from the Expert System for the Calibration of the Hydrological Simulation Program - FORTRAN (HSPEXP) Computer Program Showing Calibration Statistics for CLEAR FORK (June 28, 1974, through June 27, 1984)}

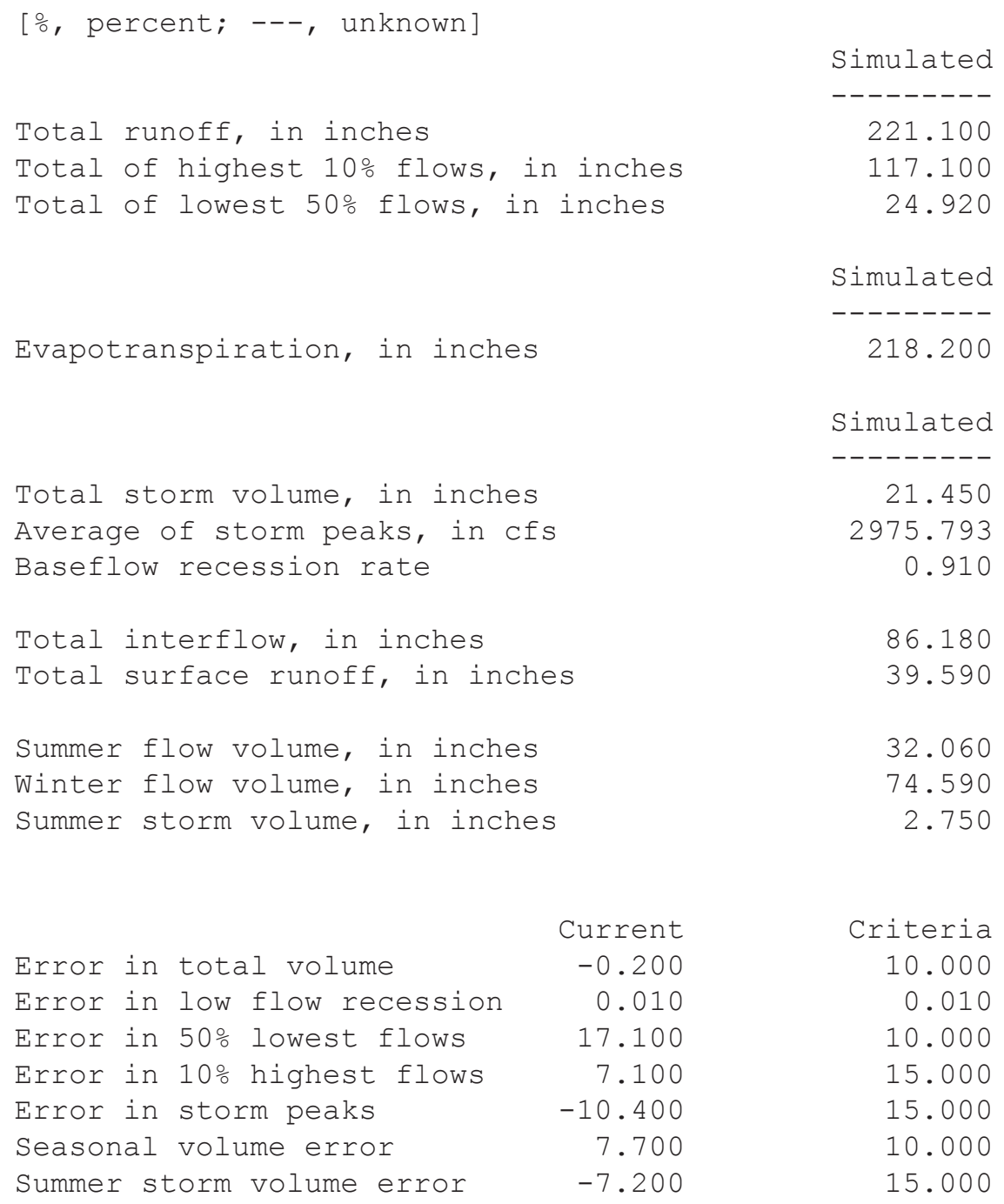

Simulated

Total runoff, in inches

Total of highest 10\% flows, in inches

Total of lowest 50\% flows, in inches

Evapotranspiration, in inches

Total storm volume, in inches

Average of storm peaks, in cfs

Baseflow recession rate

Total interflow, in inches

Total surface runoff, in inches

Summer flow volume, in inches

Winter flow volume, in inches

Summer storm volume, in inches

Current

$-0.200$

0.010

17.100

7.100

$-10.400$

7.700

$-7.200$

Simulated

218.200

Simulated

21.450

2975.793

0.910

86.180

39.590

32.060

74.590

2.750

Criteria

10.000

0.010

10.000

15.000

15.000

10.000

15.000

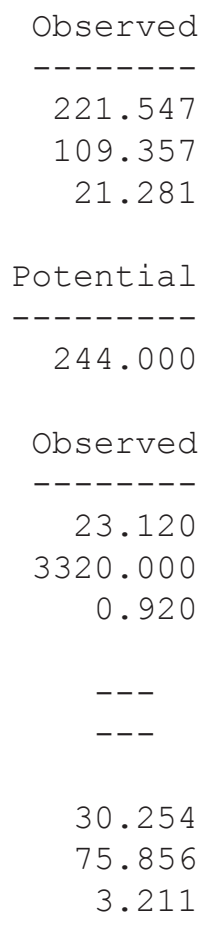

Observed

--------

221.547

109.357

21.281

Potential

244.000

Observed

23.120

3320.000

0.920

30.254

75.856

3. 211 


\section{Appendix H: Part of the Output from the Expert System for the Calibration of the Hydrological Simulation Program - FORTRAN (HSPEXP) Computer Program Showing Calibration Statistics for DUNLOW (January 1, 1970, through December 31, 1995)}

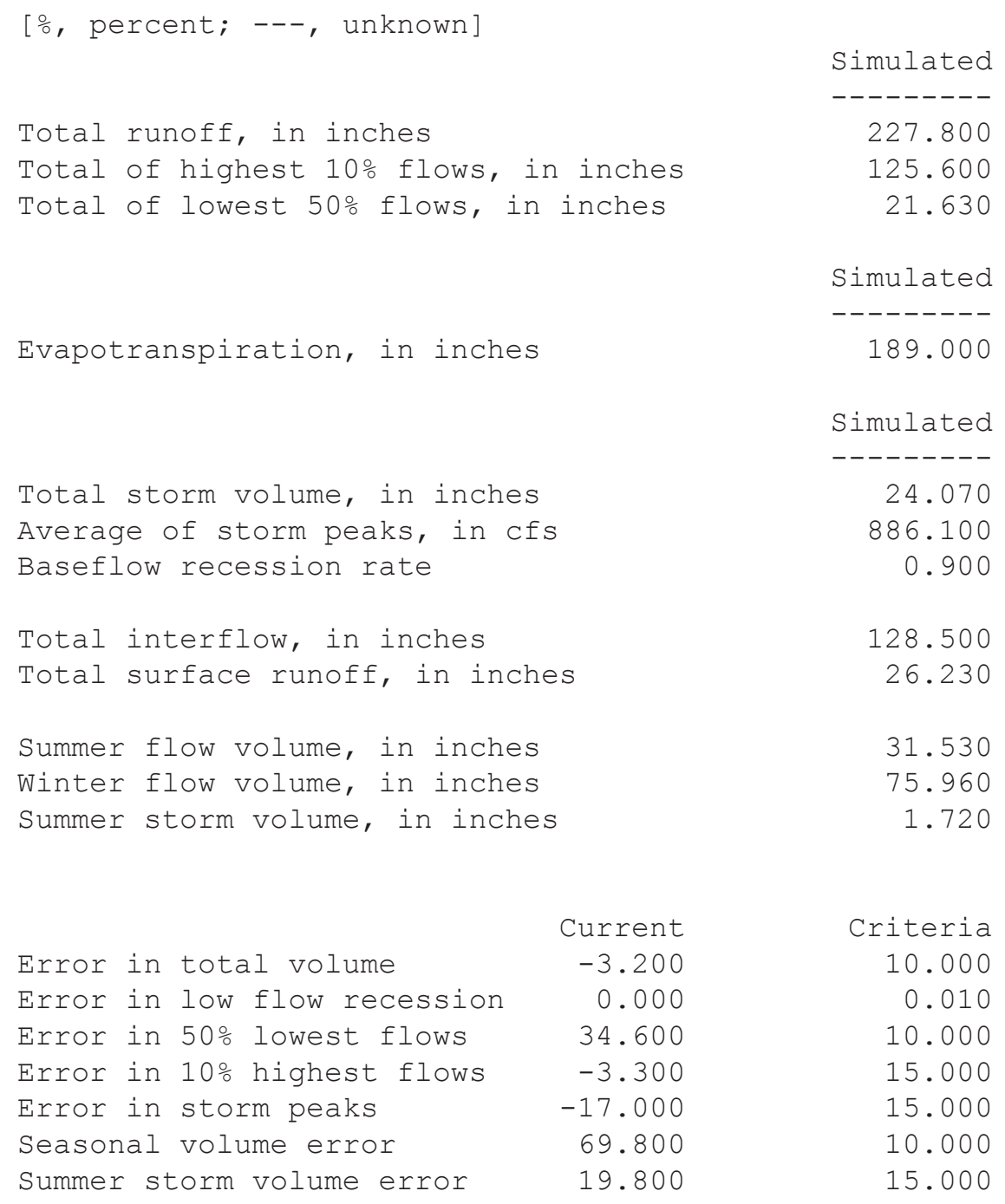

19.800

$$
\begin{array}{r}
128.500 \\
26.230 \\
31.530 \\
75.960 \\
1.720 \\
\\
\\
\text { Criteria } \\
10.000 \\
0.010 \\
10.000 \\
15.000 \\
15.000 \\
10.000 \\
15.000
\end{array}
$$

Criteria 


\section{Appendix I: Part of the Output from the Expert System for the Calibration of the Hydrological Simulation Program - FORTRAN (HSPEXP) Computer Program Showing Calibration Statistics for LOCKWOOD (October 1, 1945, through September 30, 1955)}

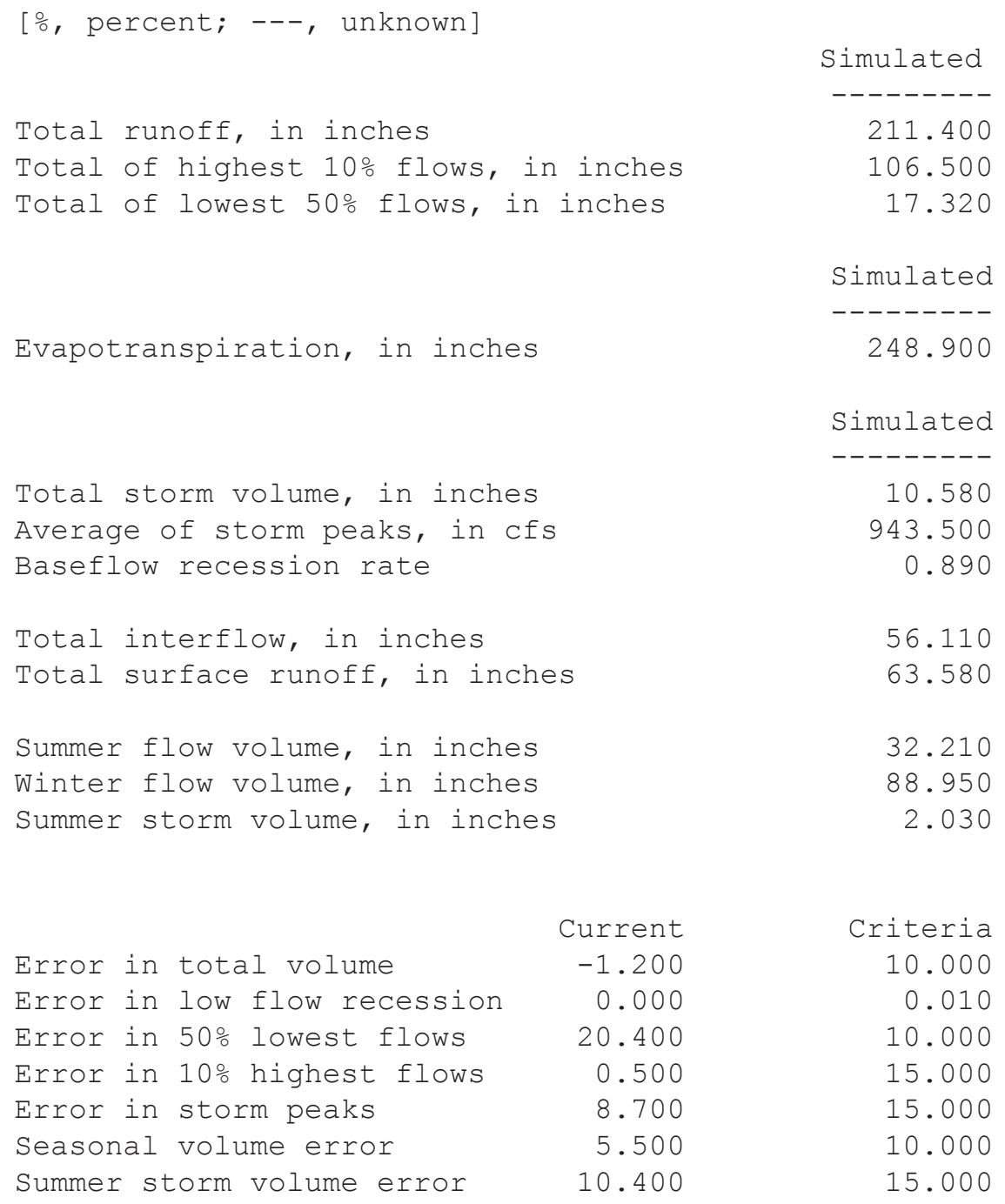

Simulated

Total runoff, in inches

Total of highest $10 \%$ flows, in inches

Total of lowest $50 \%$ flows, in inches

Evapotranspiration, in inches

Total storm volume, in inches

Average of storm peaks, in cfs

Baseflow recession rate

Total interflow, in inches

Total surface runoff, in inches

Summer flow volume, in inches

Winter flow volume, in inches

Summer storm volume, in inches

Current

$-1.200$

0.000

20.400

0.500

8.700

5.500

10.400

17.320

Simulated

248.900

Simulated

56.110

63.580

32.210

88.950

2.030

Criteria

10.000

0.010

10.000

15.000

15.000

10.000

15.000

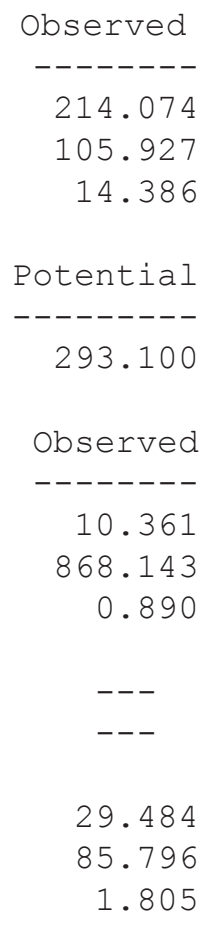

Observed

--------

214.074

105.927

14.386

Potential

293.100

Observed

10.361

868.143

0.890

29.484

85.796

1.805 


\section{Appendix J: Part of the Output from the Expert System for the Calibration of the Hydrological Simulation Program - FORTRAN (HSPEXP) Computer Program Showing Calibration Statistics for MIDVALE (May 1, 1915, through April 30, 1933)}

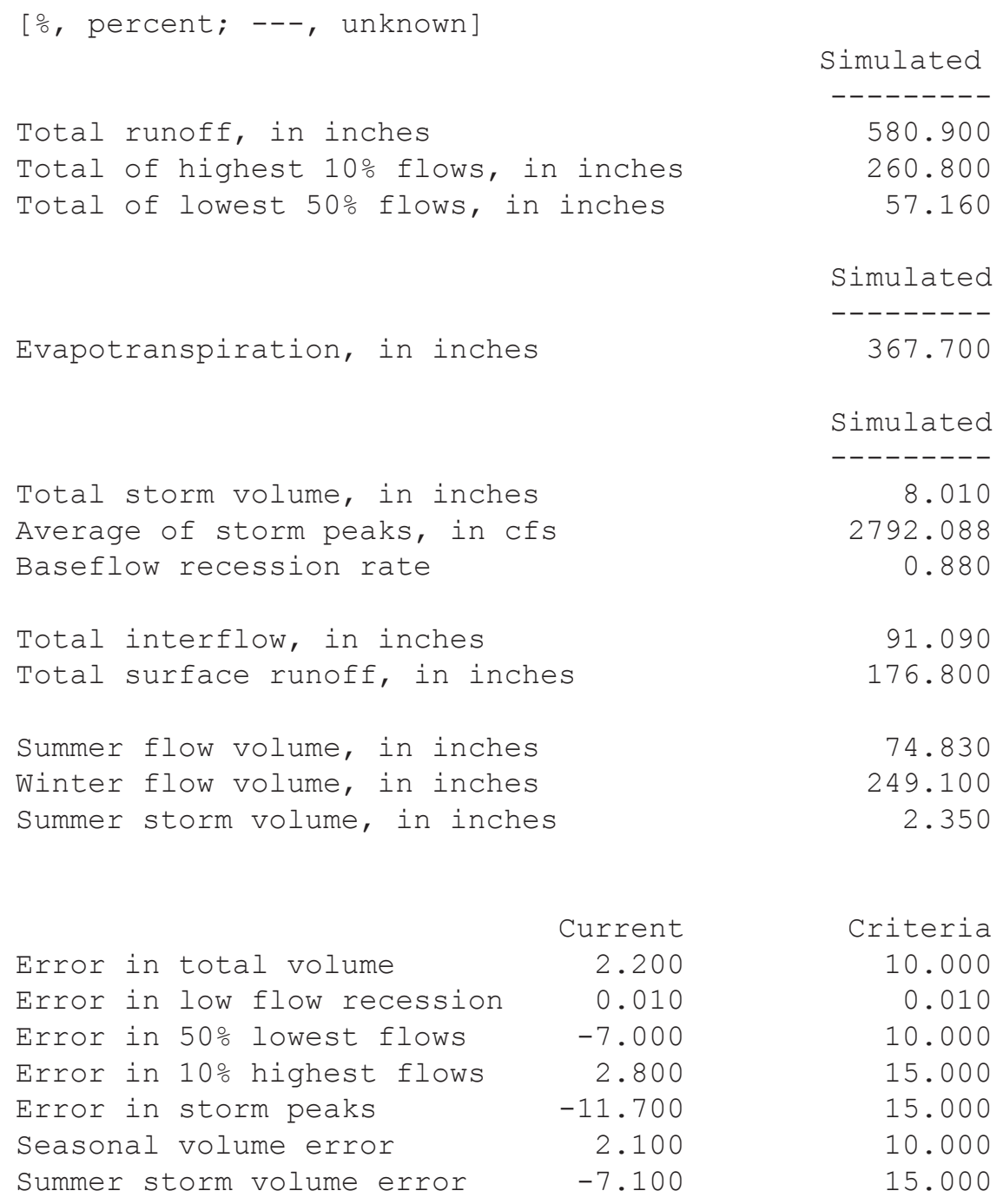

Simulated

Total runoff, in inches

Total of highest $10 \%$ flows, in inches

Total of lowest $50 \%$ flows, in inches

Evapotranspiration, in inches

Total storm volume, in inches

Average of storm peaks, in cfs

Baseflow recession rate

Total interflow, in inches

Total surface runoff, in inches

Summer flow volume, in inches

Winter flow volume, in inches

Summer storm volume, in inches

Current

2.200

0.010

$-7.000$

2.800

$-11.700$

2.100

$-7.100$

57.160

Simulated

367.700

Simulated

8.010

2792.088

0.880

91.090

176.800

74.830

249.100

2.350

Criteria

10.000

0.010

10.000

15.000

15.000

10.000

15.000

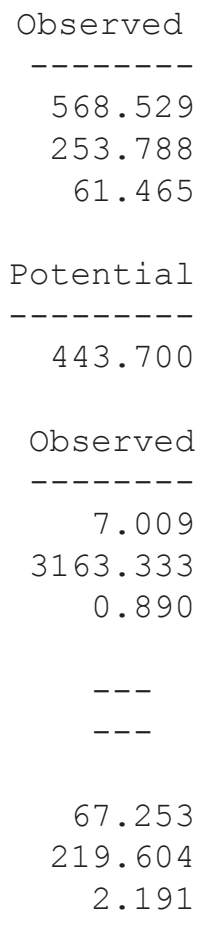

Observed

--------

568.529

253.788

61.465

Potential

443.700

Observed

7.009

3163.333

0.890

67.253

219.604

2.191 


\section{Appendix K: Part of the Output from the Expert System for the Calibration of the Hydrological Simulation Program - FORTRAN (HSPEXP) Computer Program Showing Calibration Statistics for PANTHER (January 1, 1970, through September 30, 1986)}

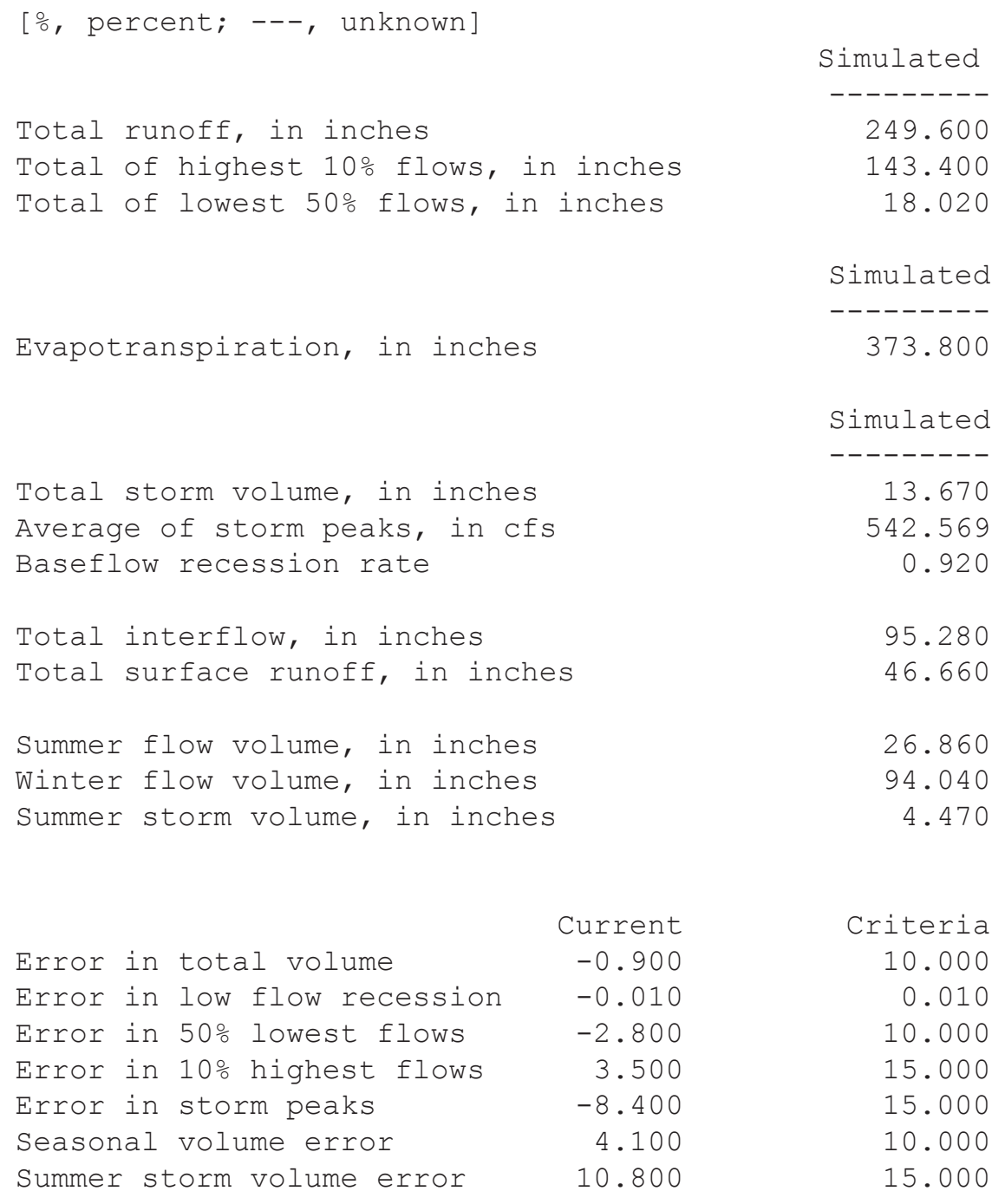

Simulated

Total runoff, in inches

Total of highest $10 \%$ flows, in inches

Total of lowest $50 \%$ flows, in inches

Evapotranspiration, in inches

Total storm volume, in inches

Average of storm peaks, in cfs

Baseflow recession rate

Total interflow, in inches

Total surface runoff, in inches

Summer flow volume, in inches

Winter flow volume, in inches

Summer storm volume, in inches

Current

$-0.900$

$-0.010$

$-2.800$

3.500

$-8.400$

4.100

10.800

249.600
143.400
18.020
Simulated
-173.800
Simulated
------
13.670
542.569
0.920
95.280
46.660

26.860
94.040
4.470

Criteria
10.000
0.010
10.000
15.000
15.000
10.000
15.000

error

10.800

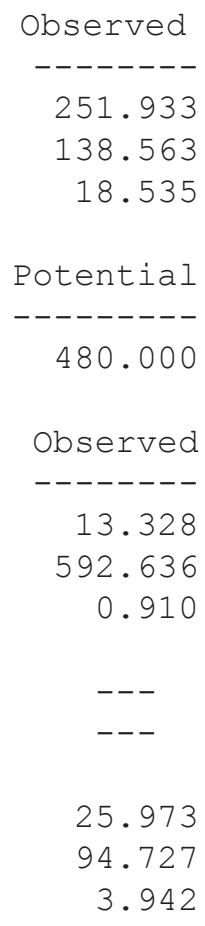

Observed

--------

251.933

138.563

18.535

Potential

480.000

Observed

13.328

592.636

0.910

25.973

94.727

3.942 


\section{Appendix L: Part of the Output from the Expert System for the Calibration of the Hydrological Simulation Program - FORTRAN (HSPEXP) Computer Program Showing Calibration Statistics for VAUGHAN (November 18, 1999, through September 29, 2001)}

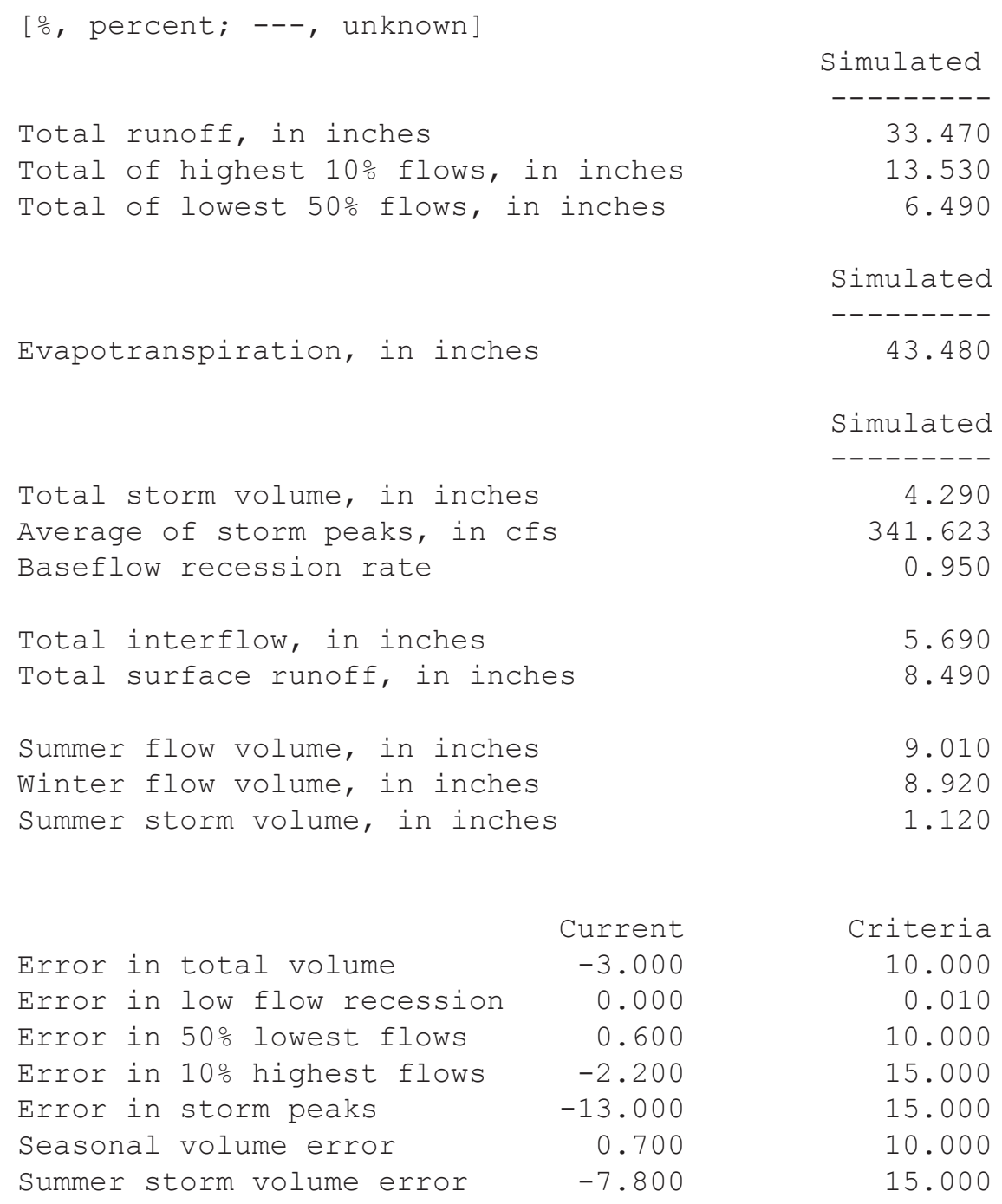

Simulated

Total runoff, in inches

Total of highest $10 \%$ flows, in inches

Total of lowest $50 \%$ flows, in inches

Evapotranspiration, in inches

Total storm volume, in inches

Average of storm peaks, in cfs

Baseflow recession rate

Total interflow, in inches

Total surface runoff, in inches

Summer flow volume, in inches

Winter flow volume, in inches

Summer storm volume, in inches

Current

$-3.000$

0.000

0.600

$-2.200$

$-13.000$

0.700

$-7.800$

Simulated

43.480

Simulated

4.290

341.623

0.950

5.690

8.490

9.010

8.920

1.120

Criteria

10.000

0.010

10.000

15.000

15.000

10.000

15.000

Summer storm volume error

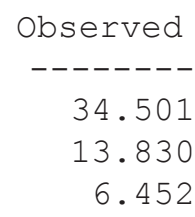

Potential

55.690

Observed

4.093
392.625

0.950

10.416

10.392

1.155 
Appendix M: Part of the Output from the Expert System for the Calibration of the Hydrological Simulation Program - FORTRAN (HSPEXP) Computer Program Showing Calibration Hydrographs for the Eight Study Basins in This Study 


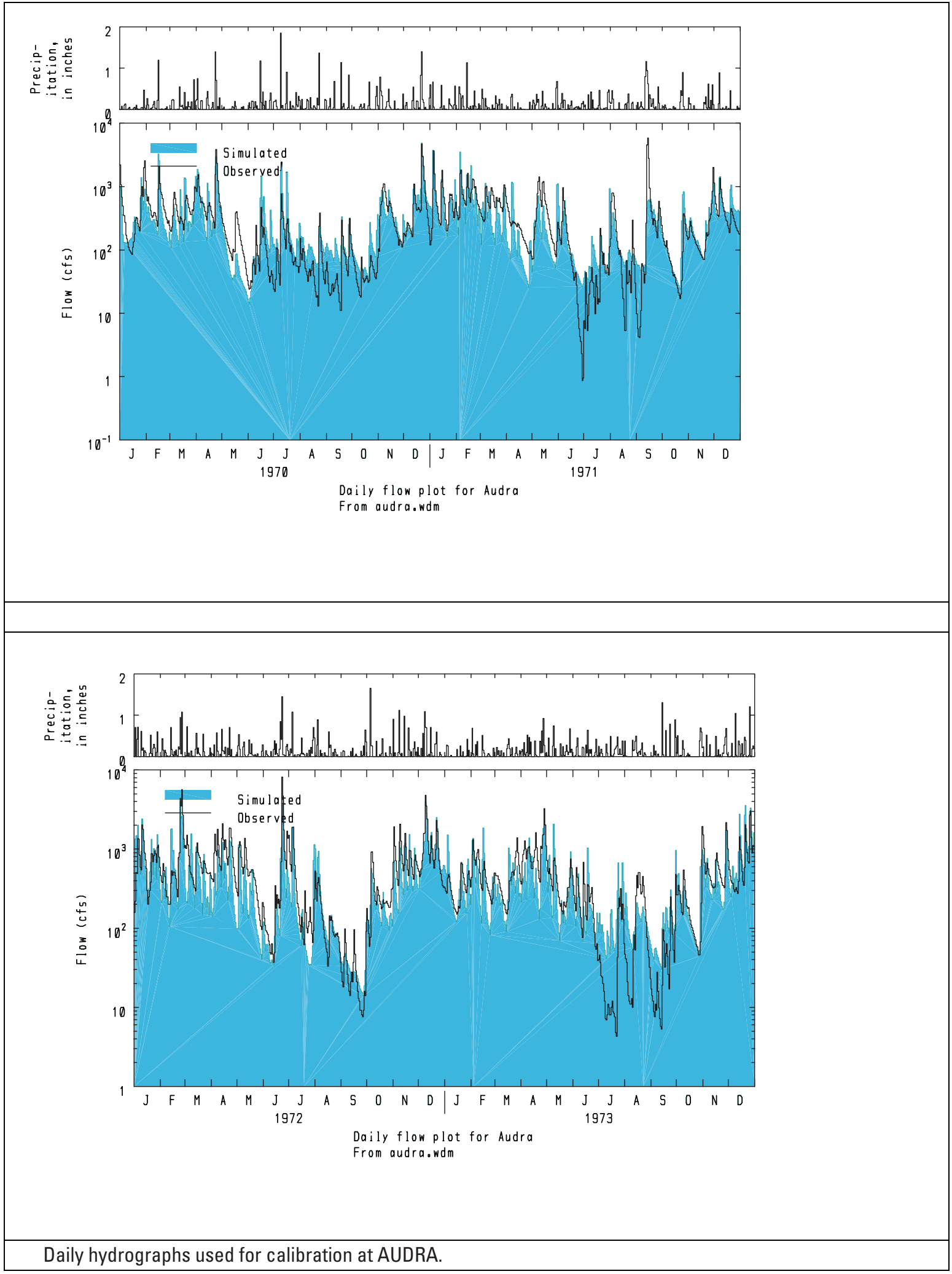




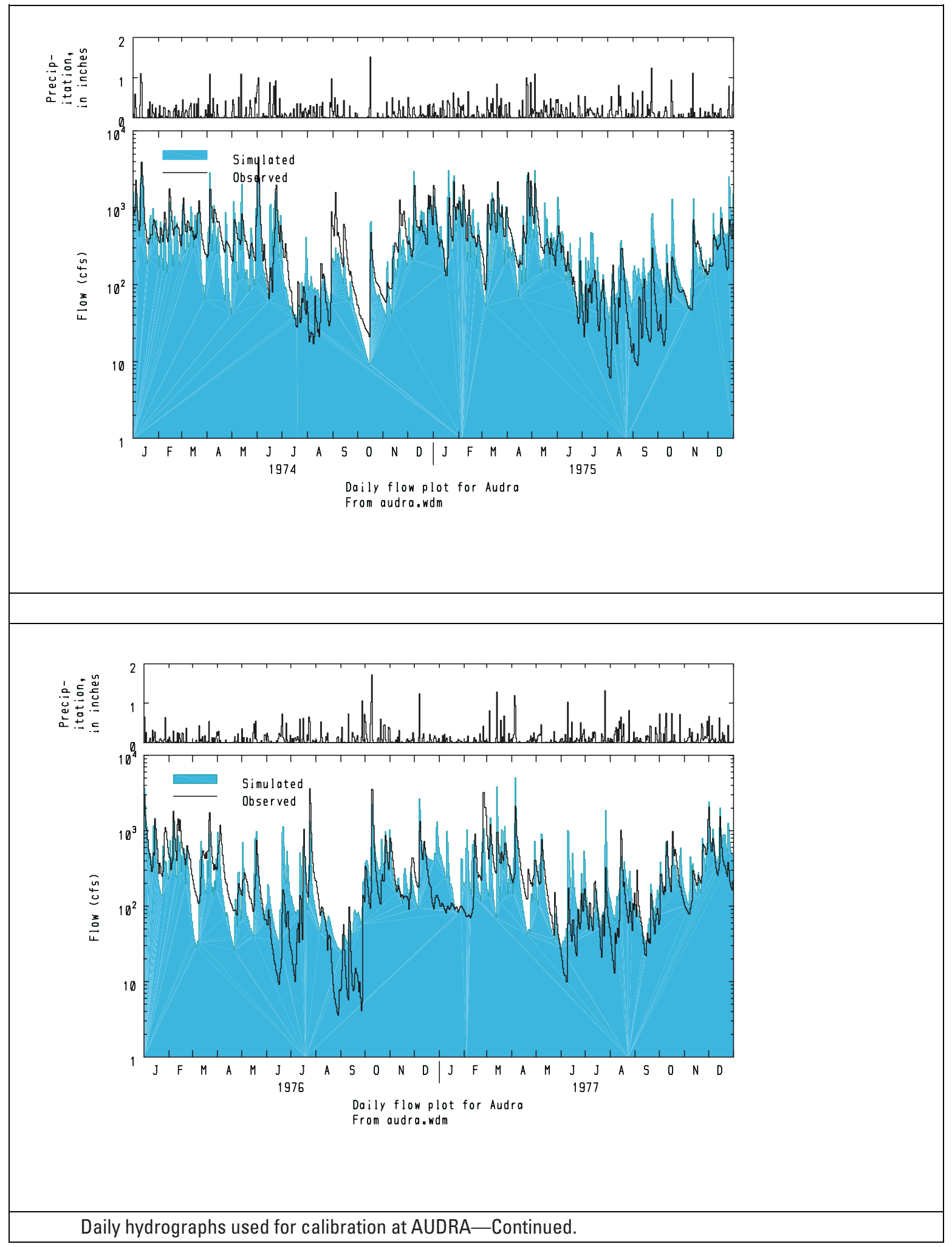




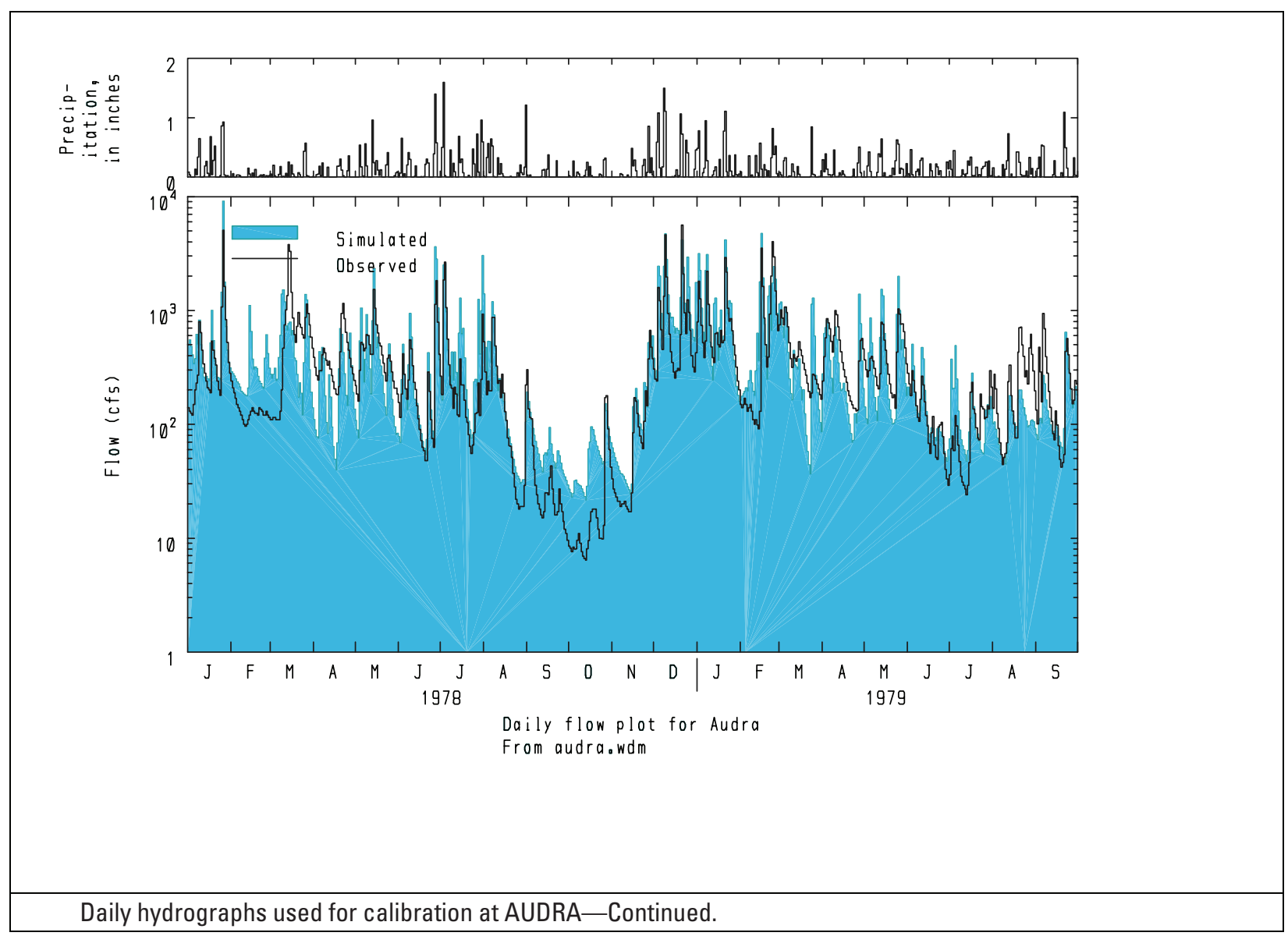




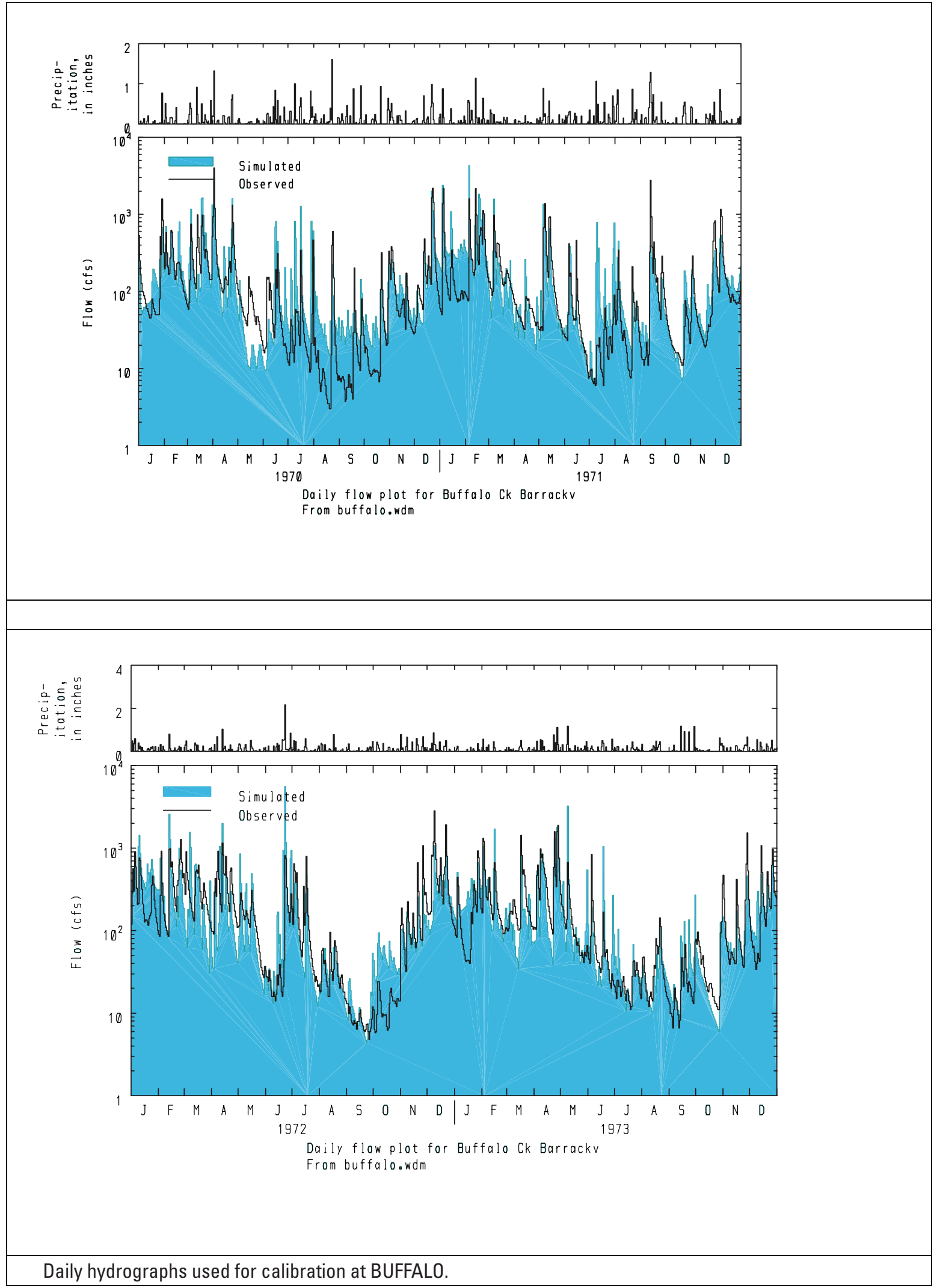




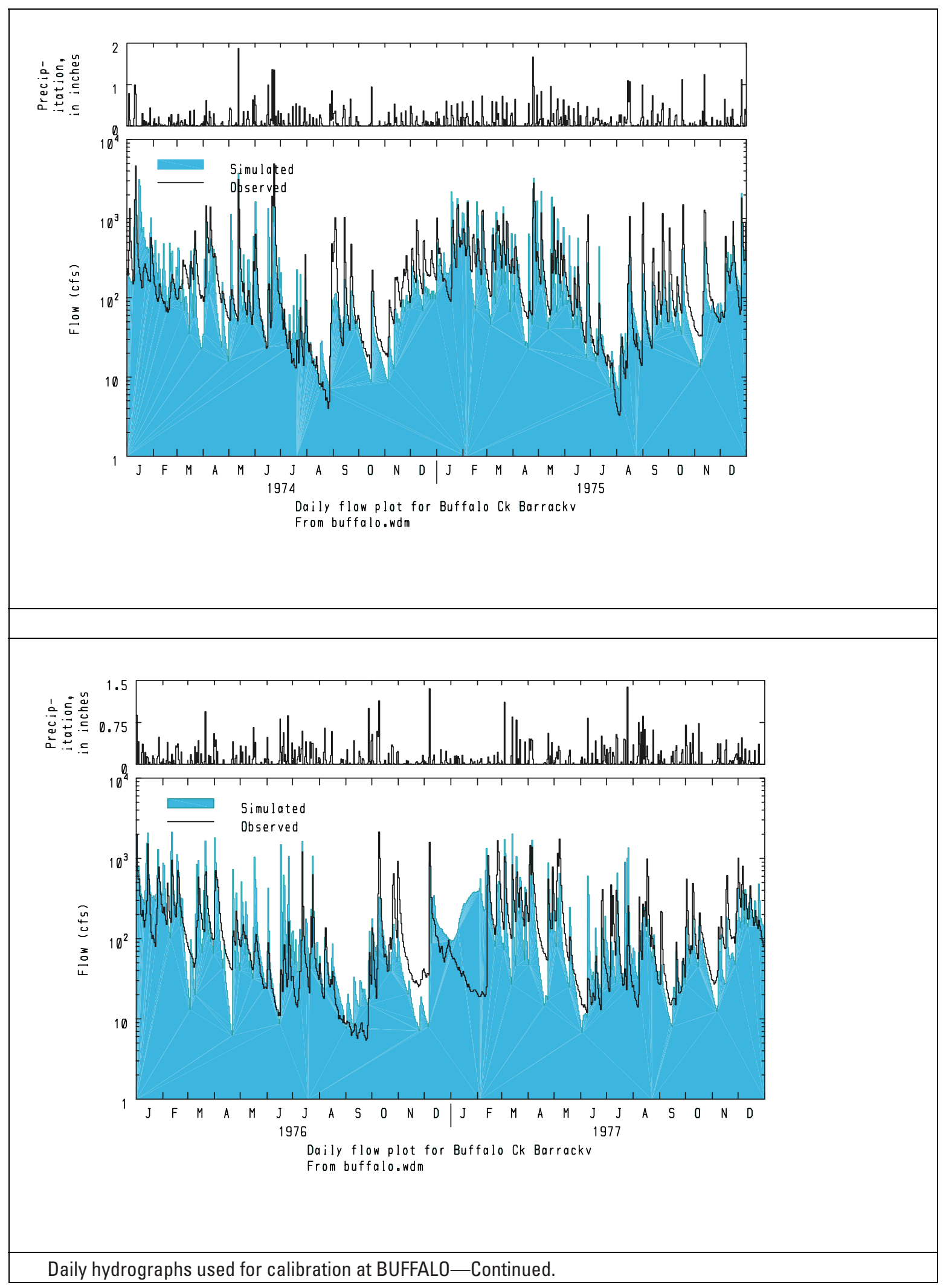




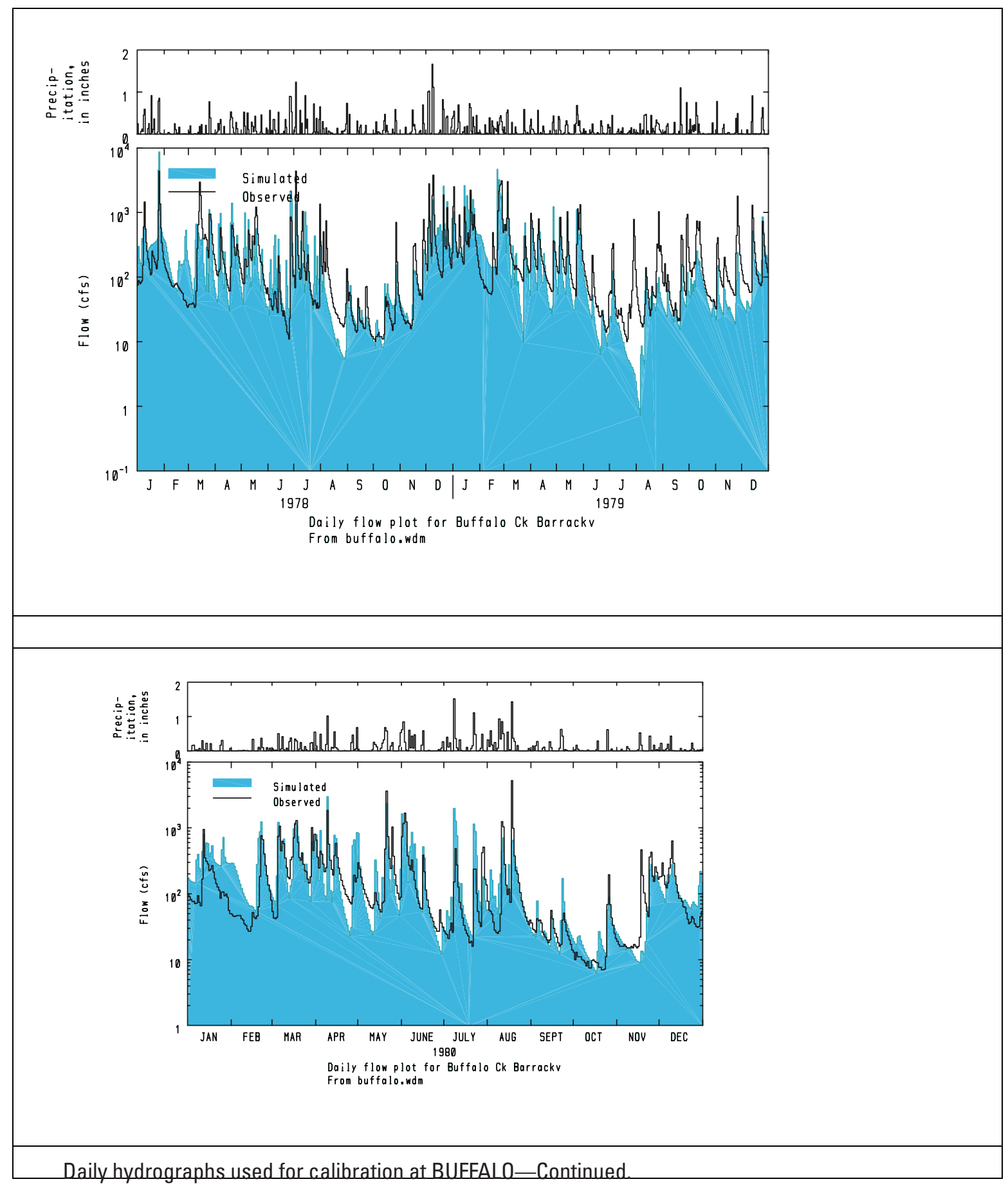




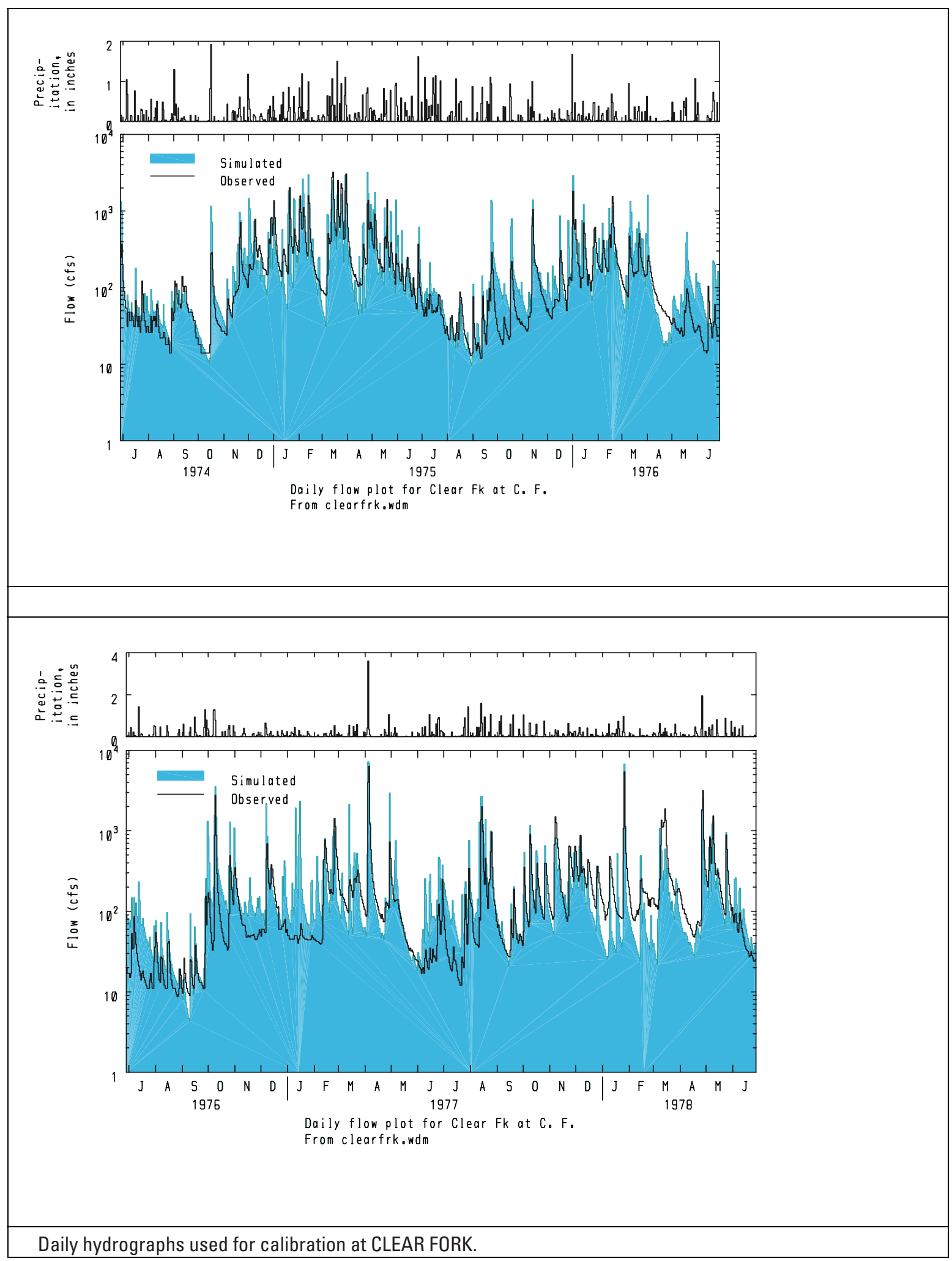




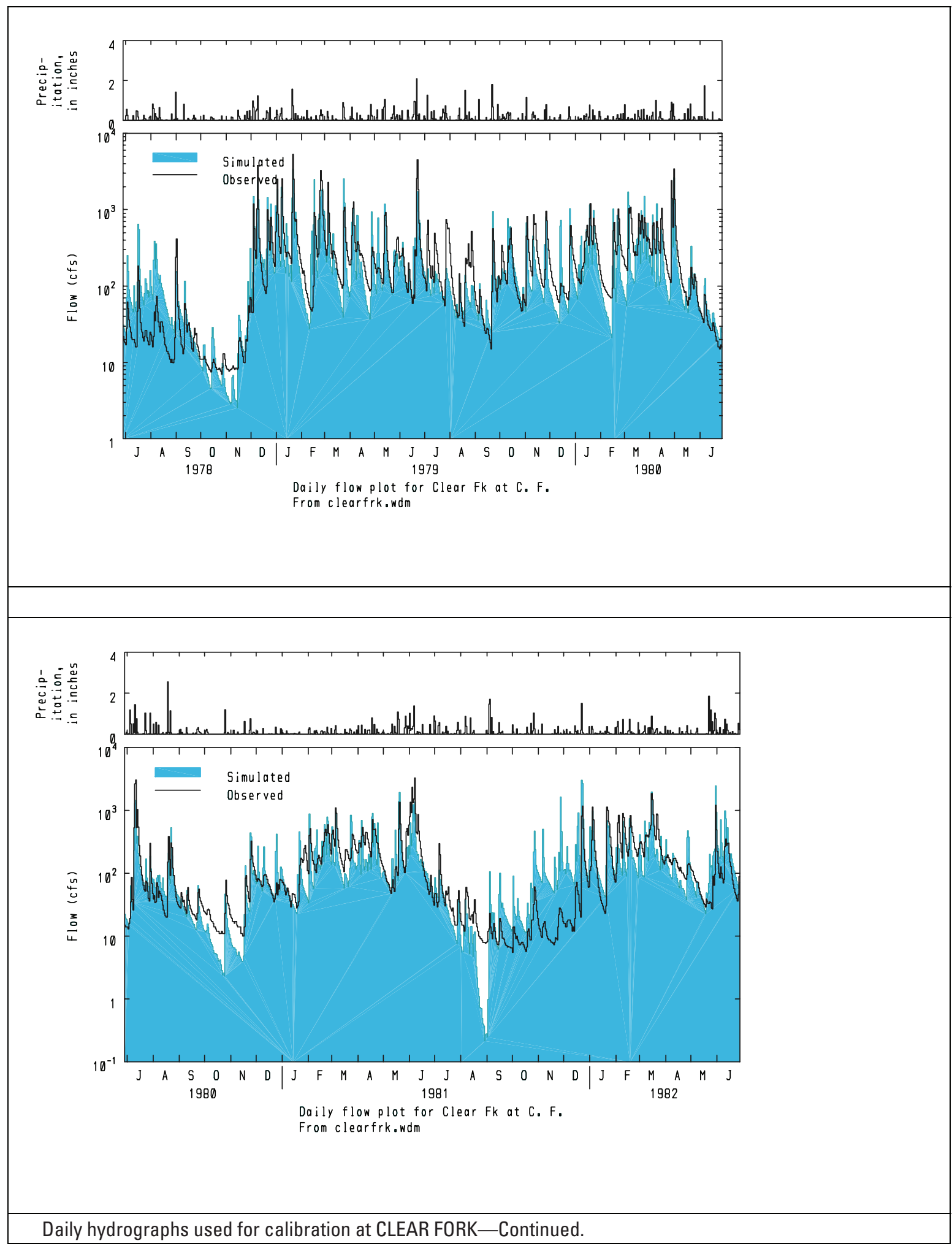




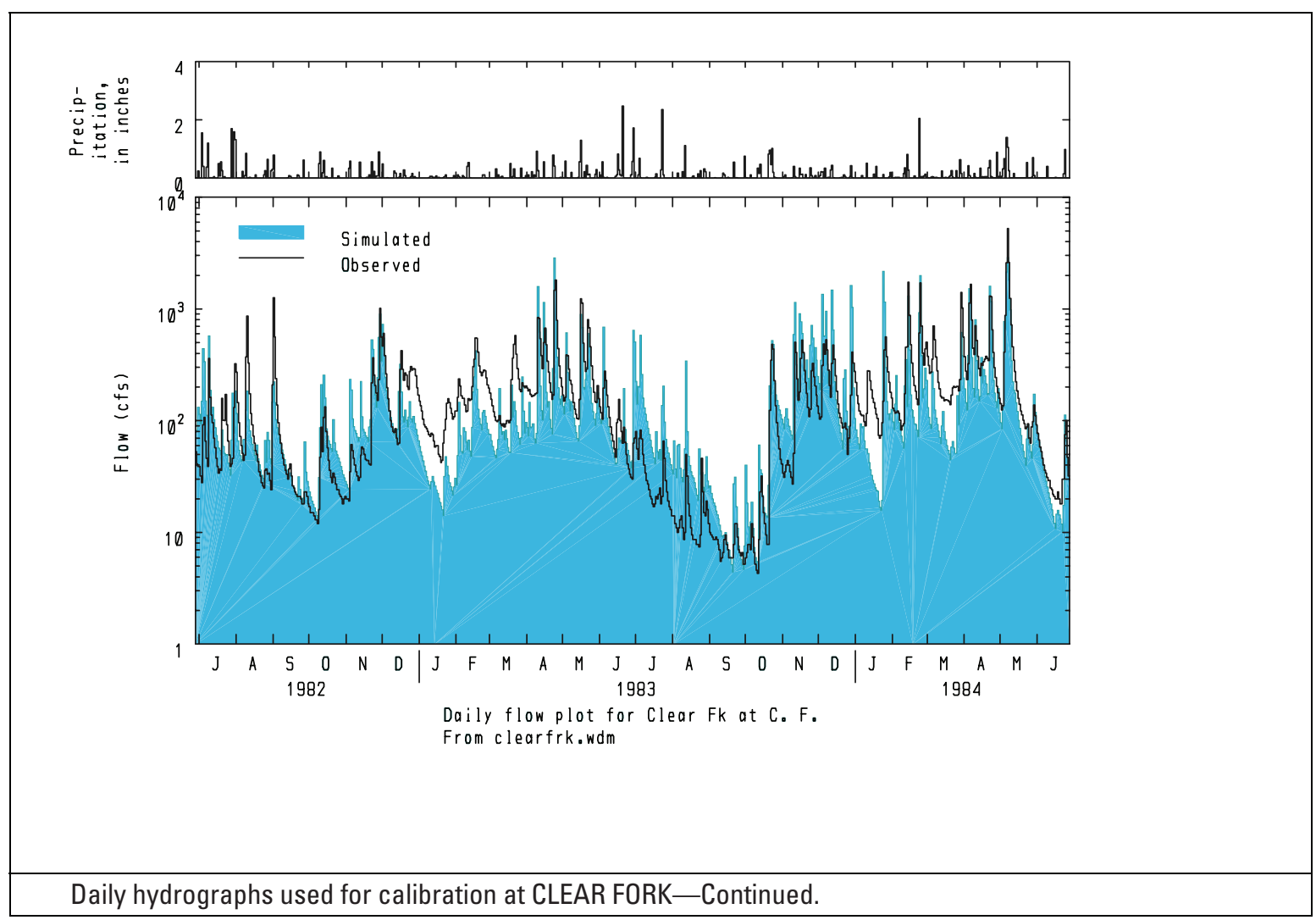




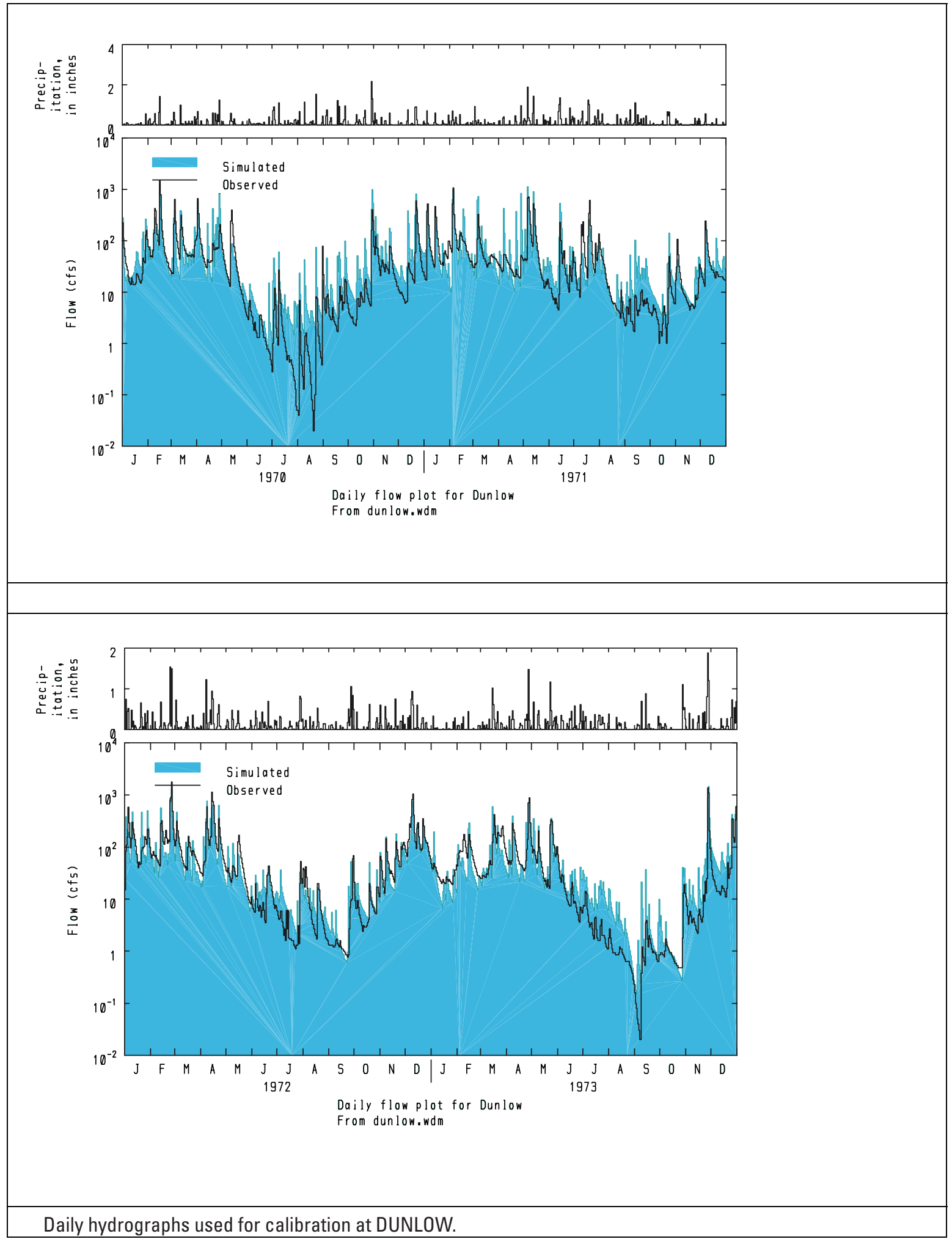




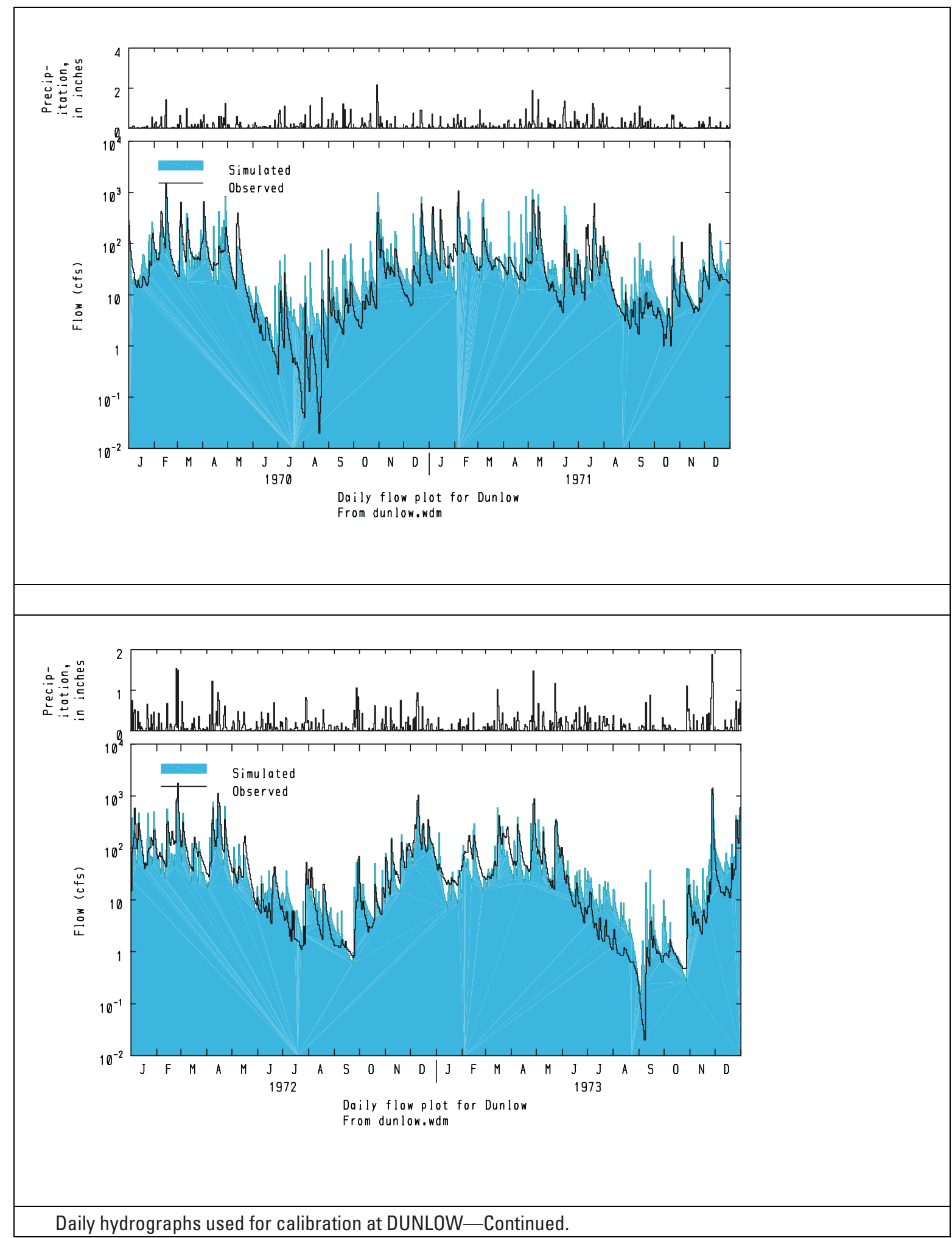




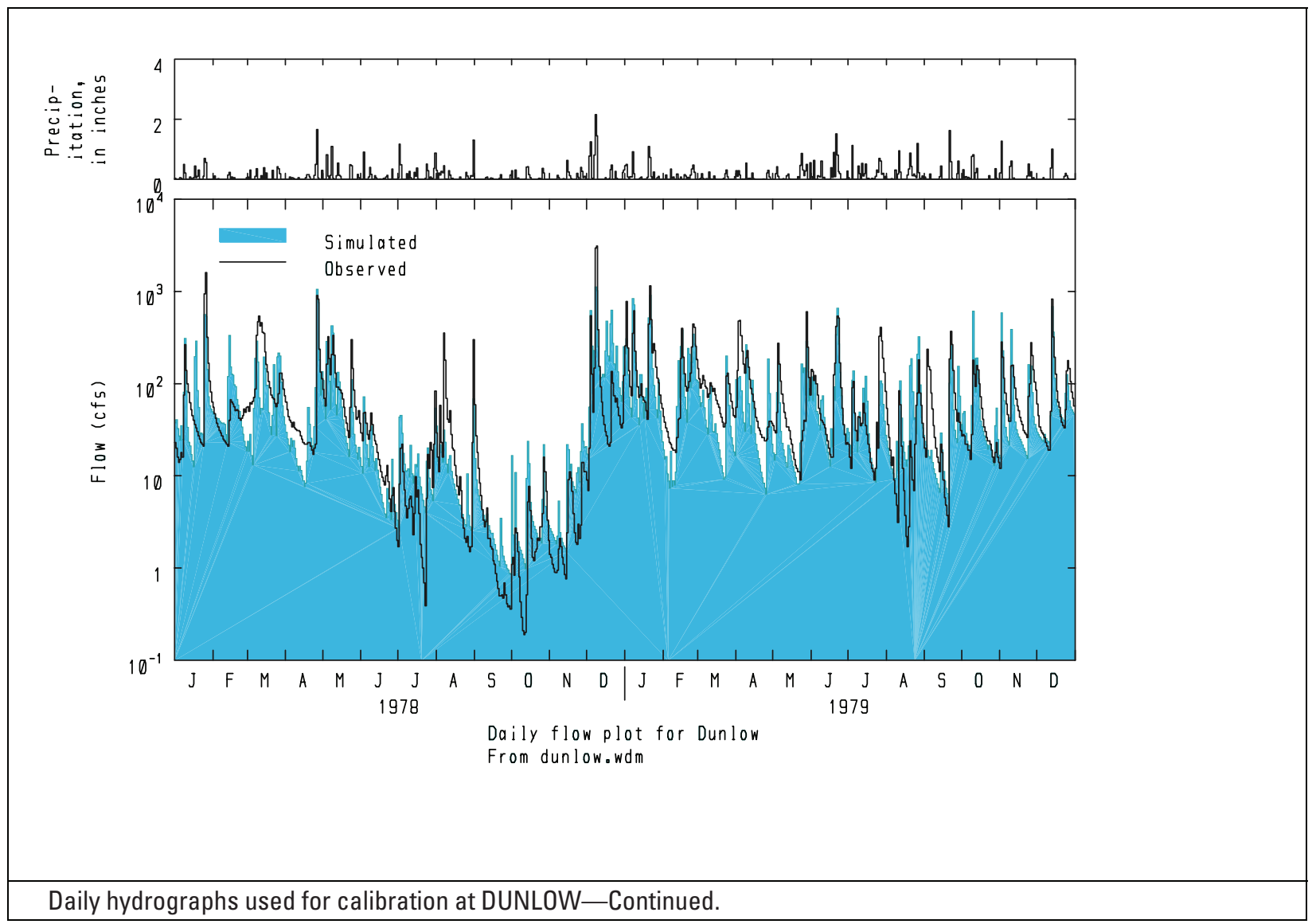




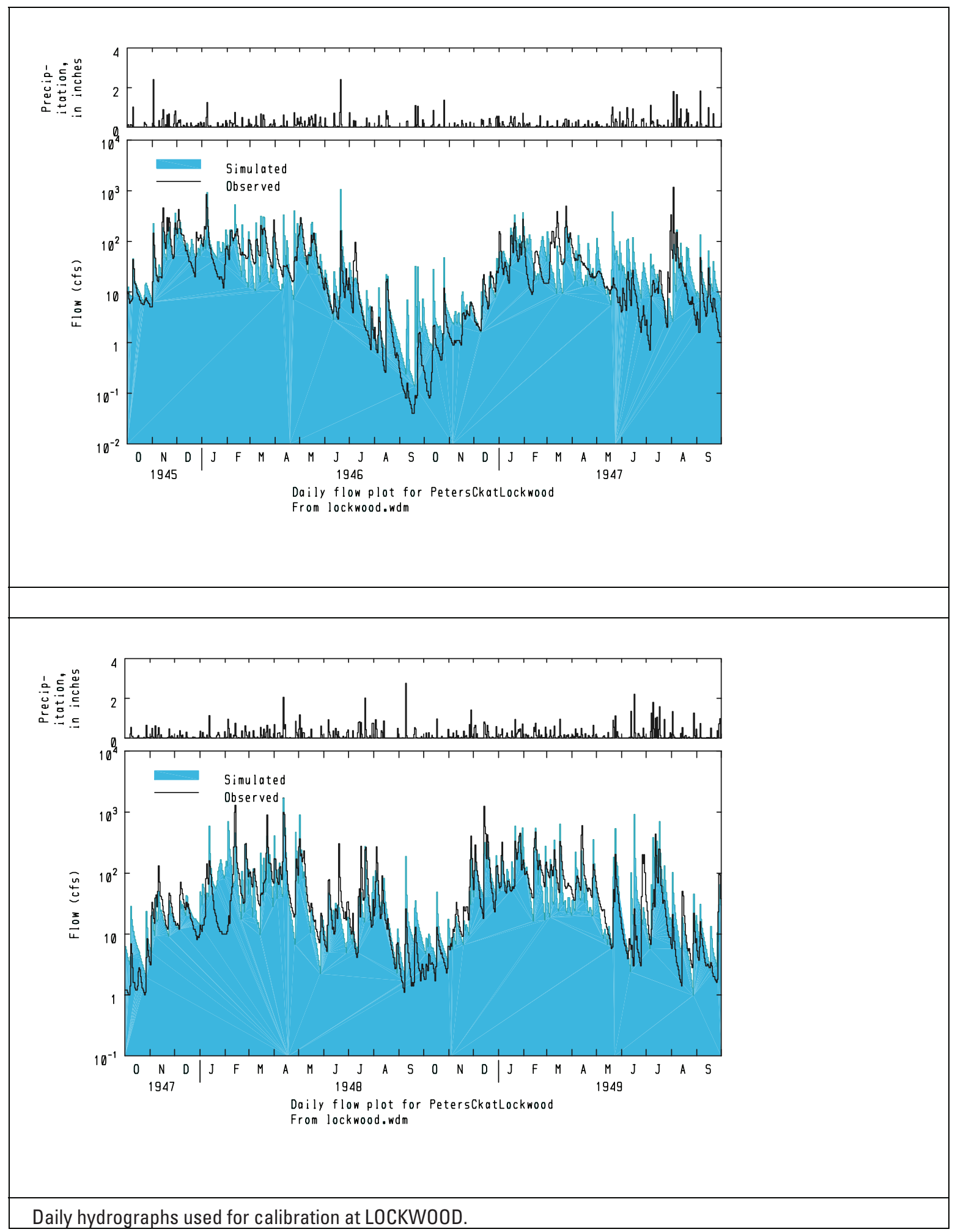




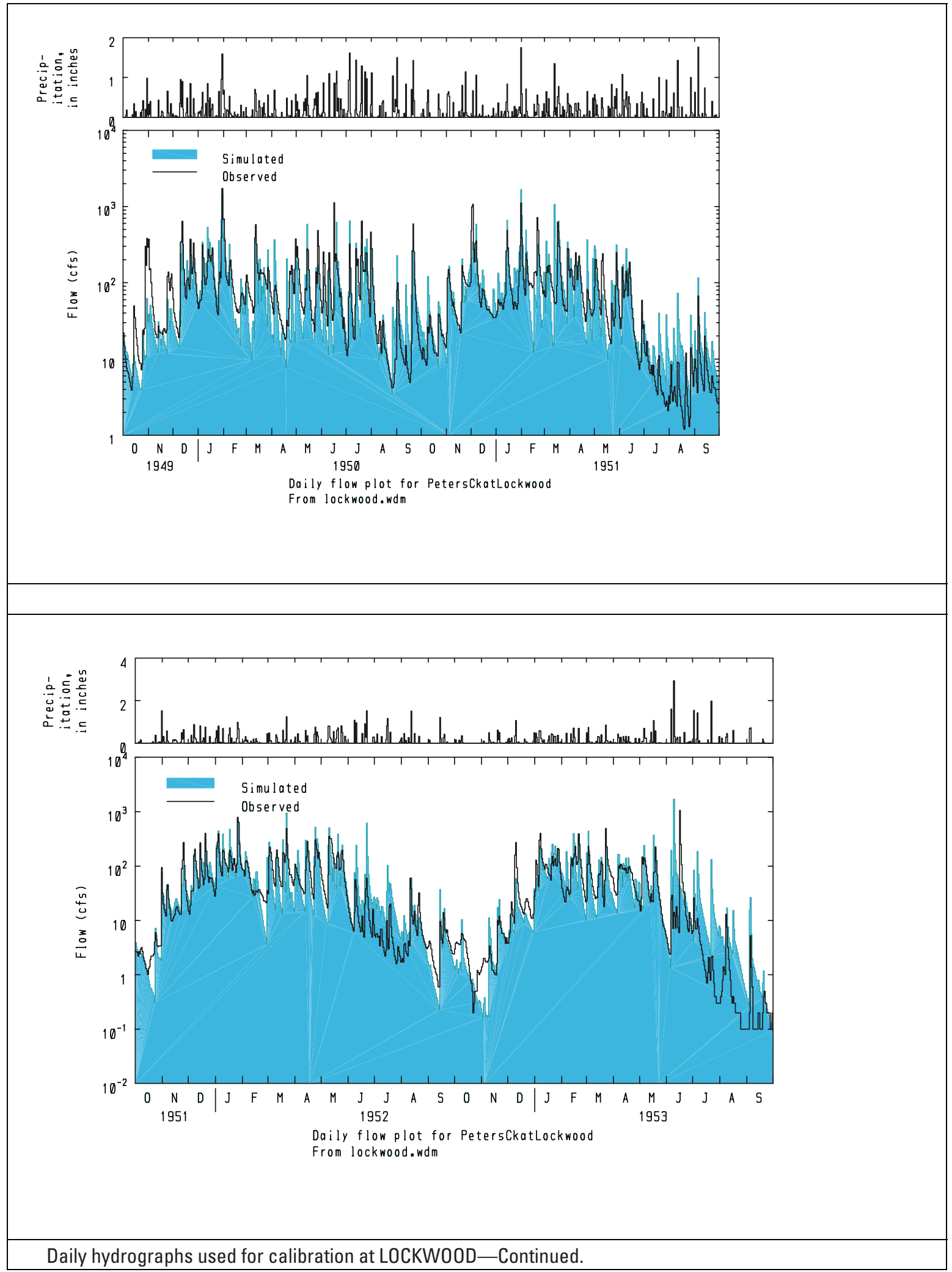




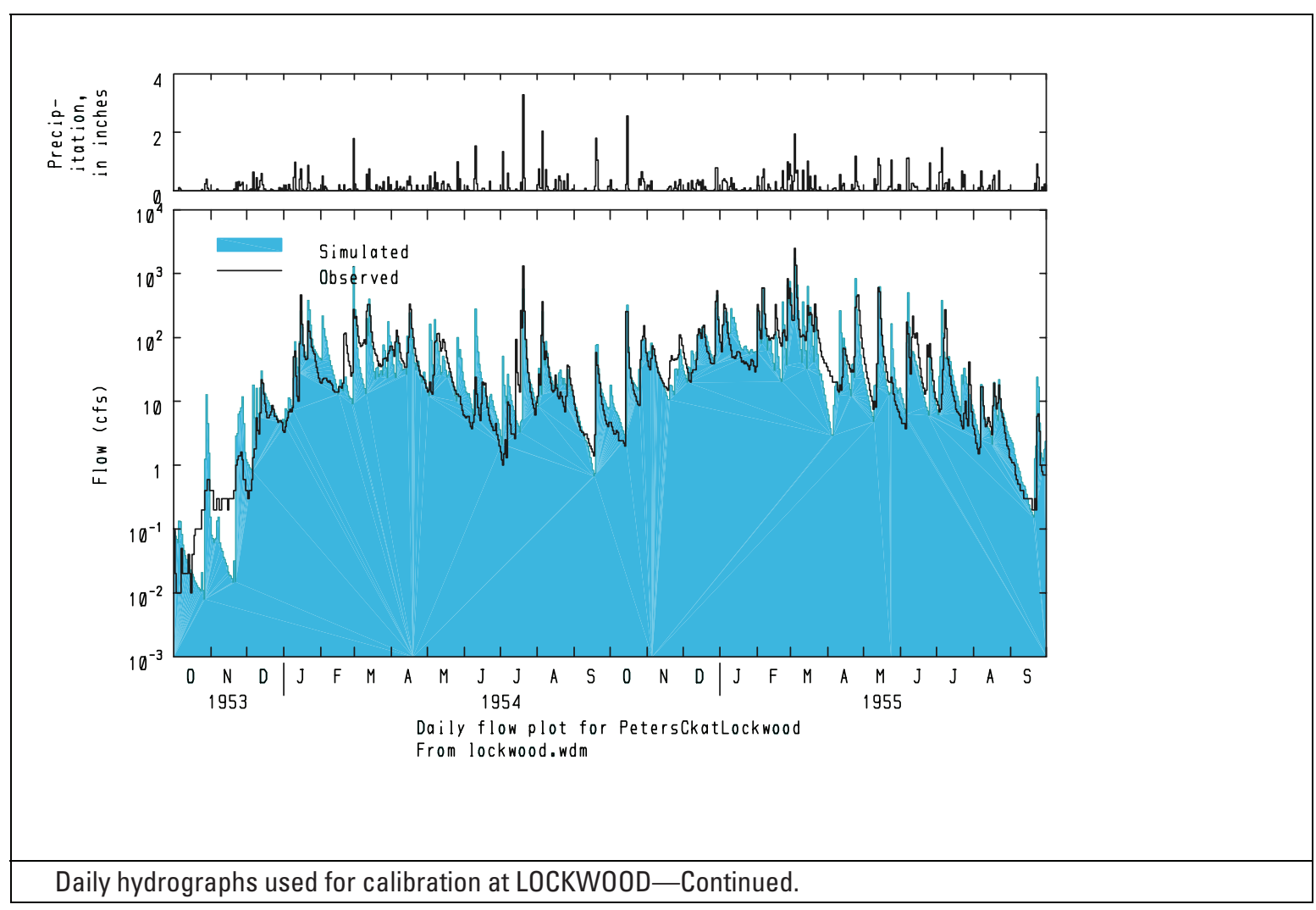




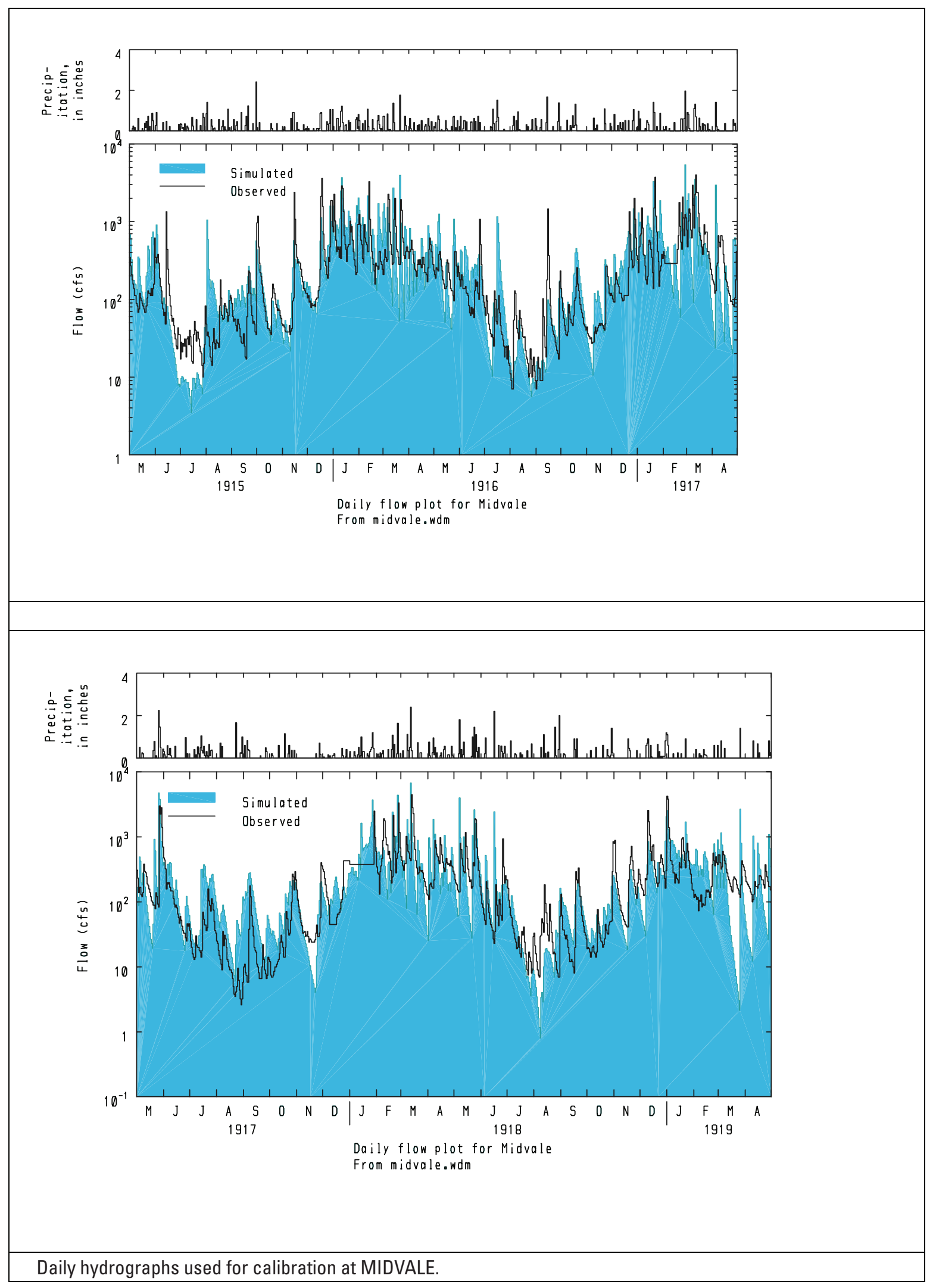




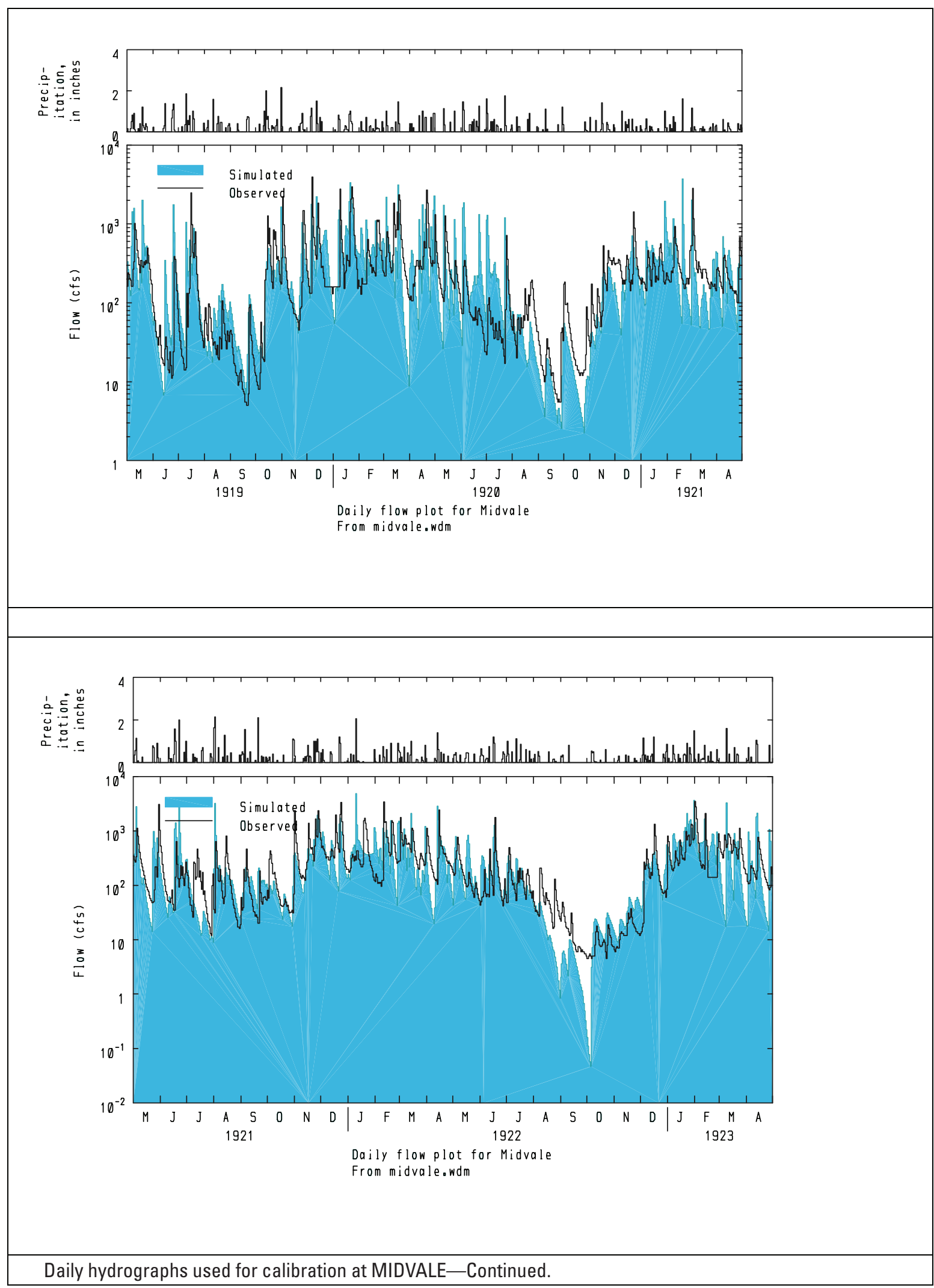




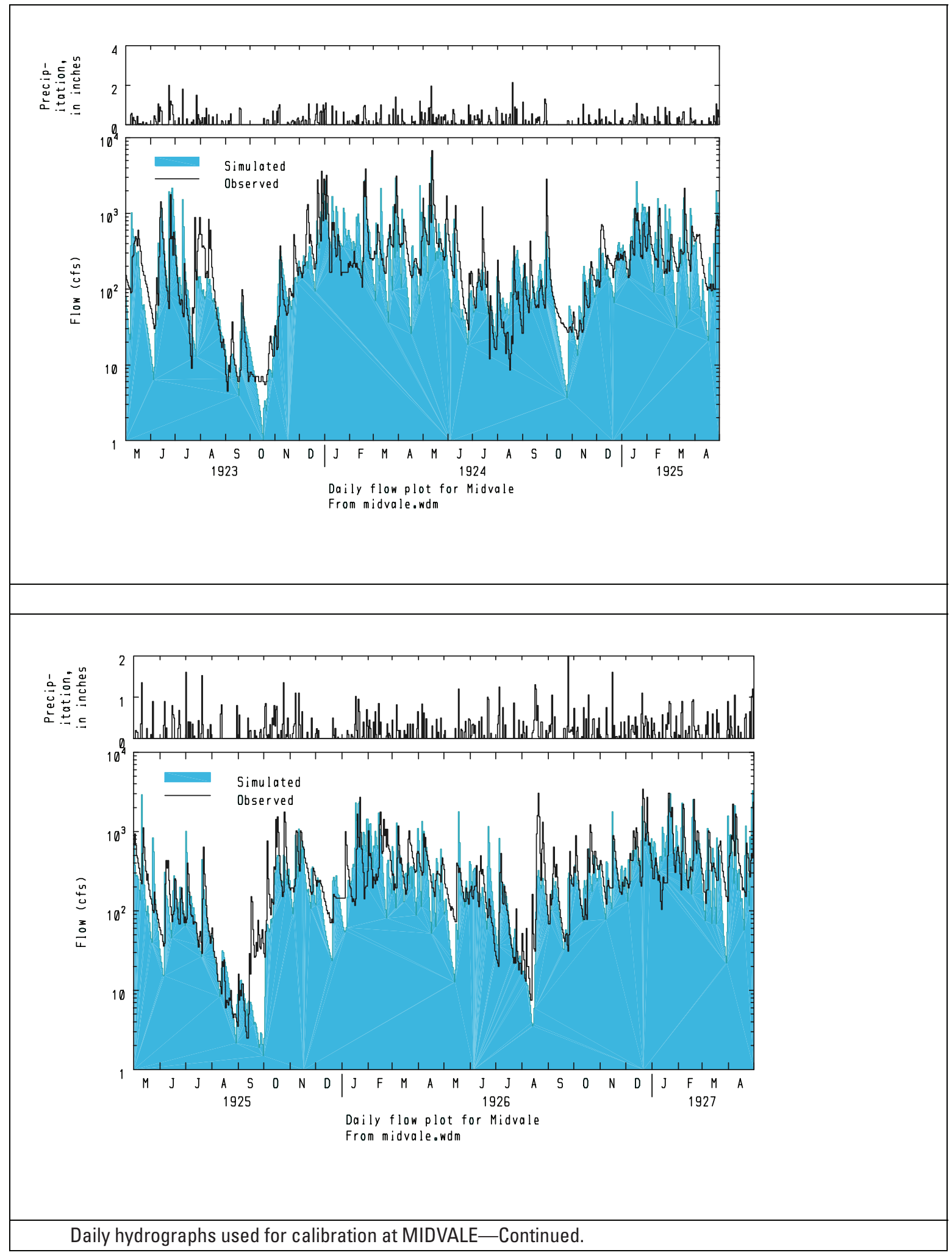




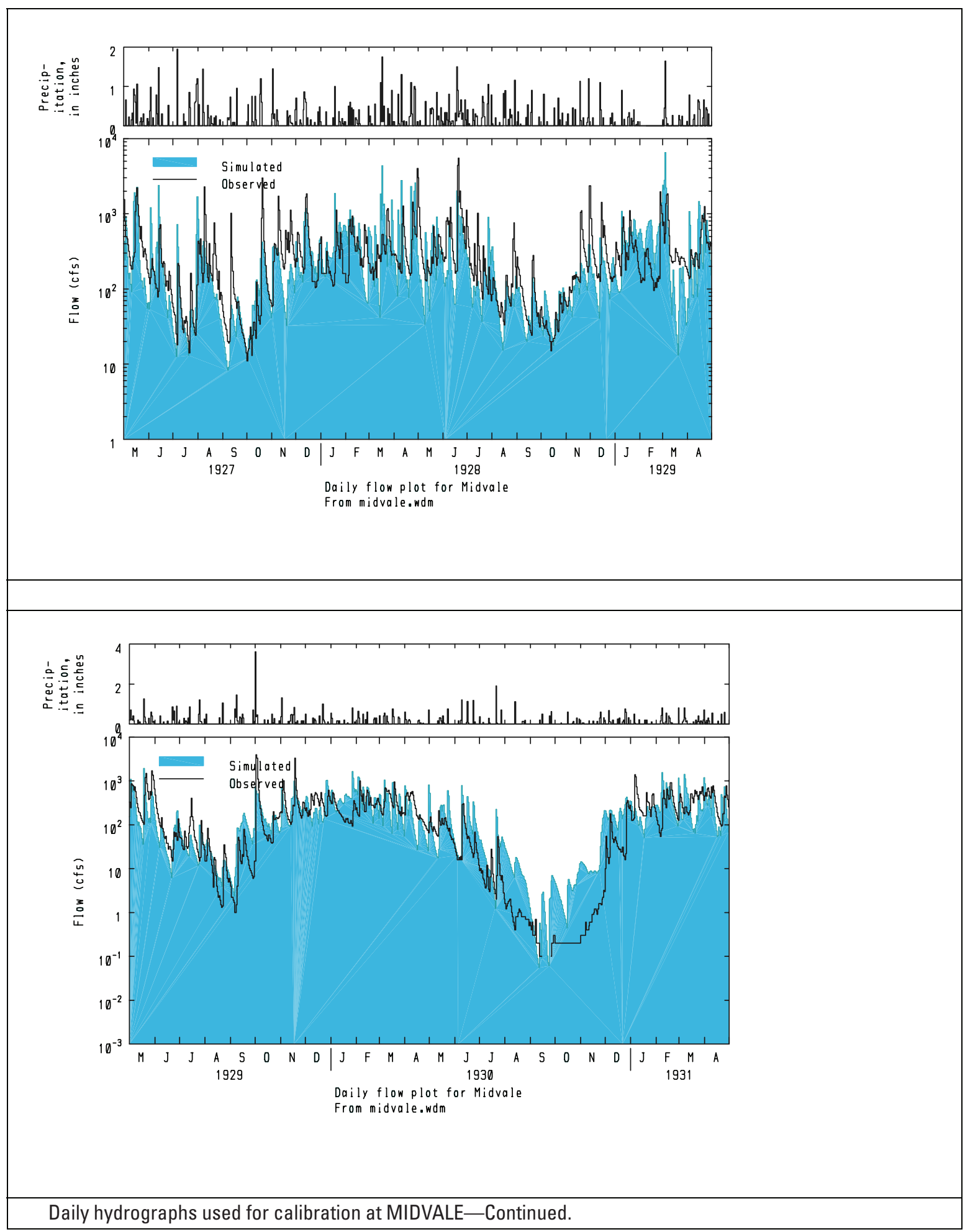




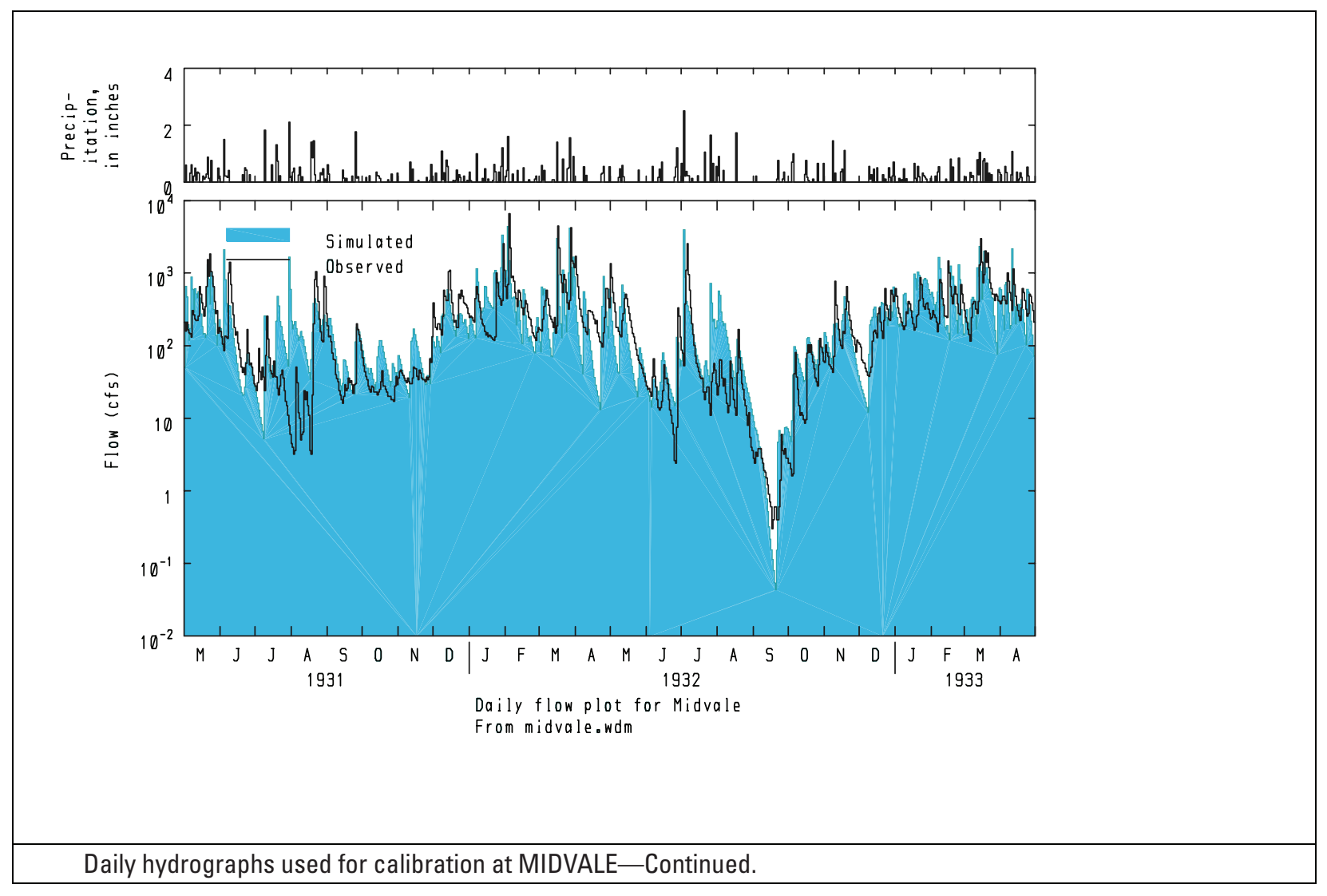




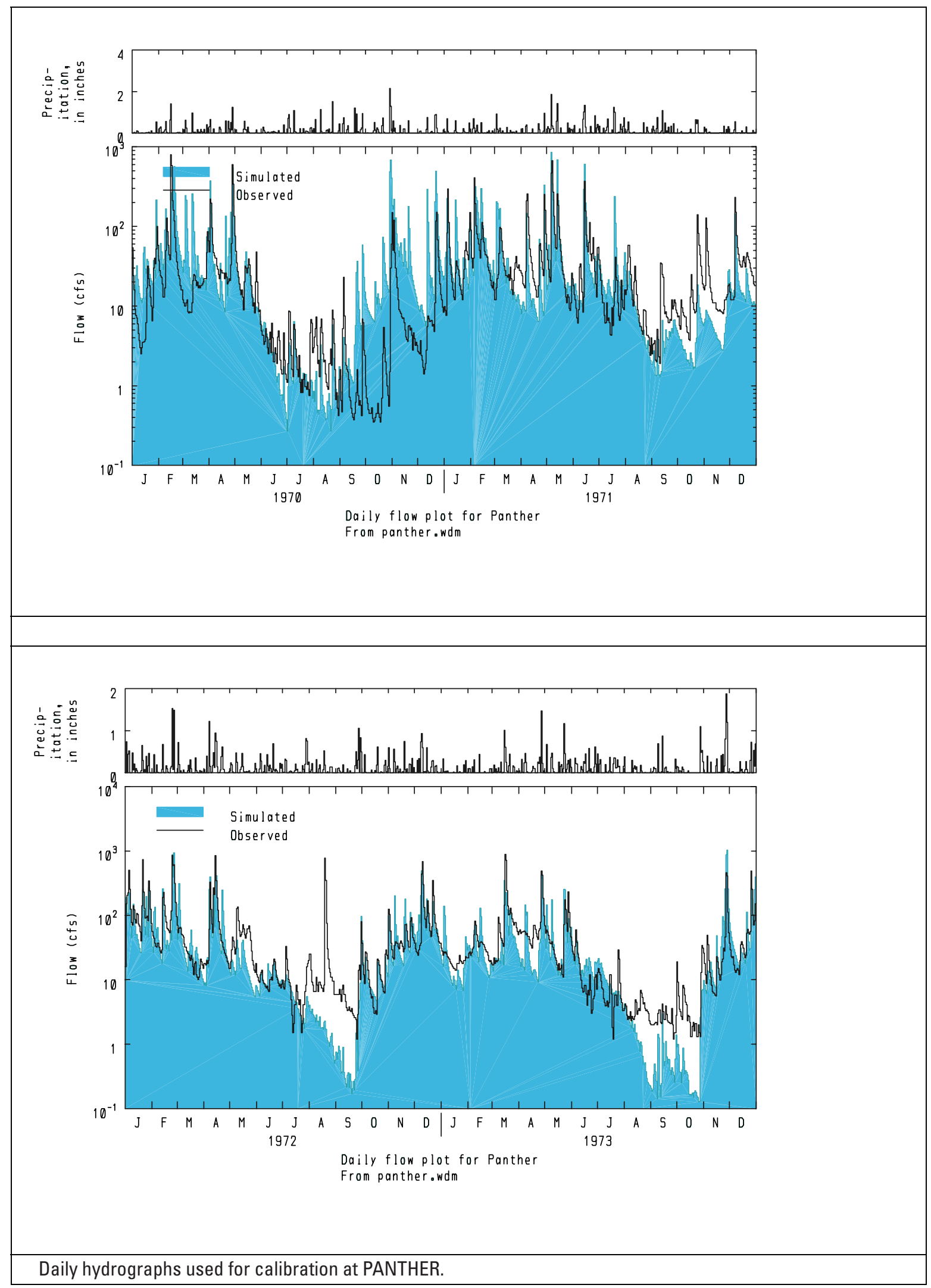




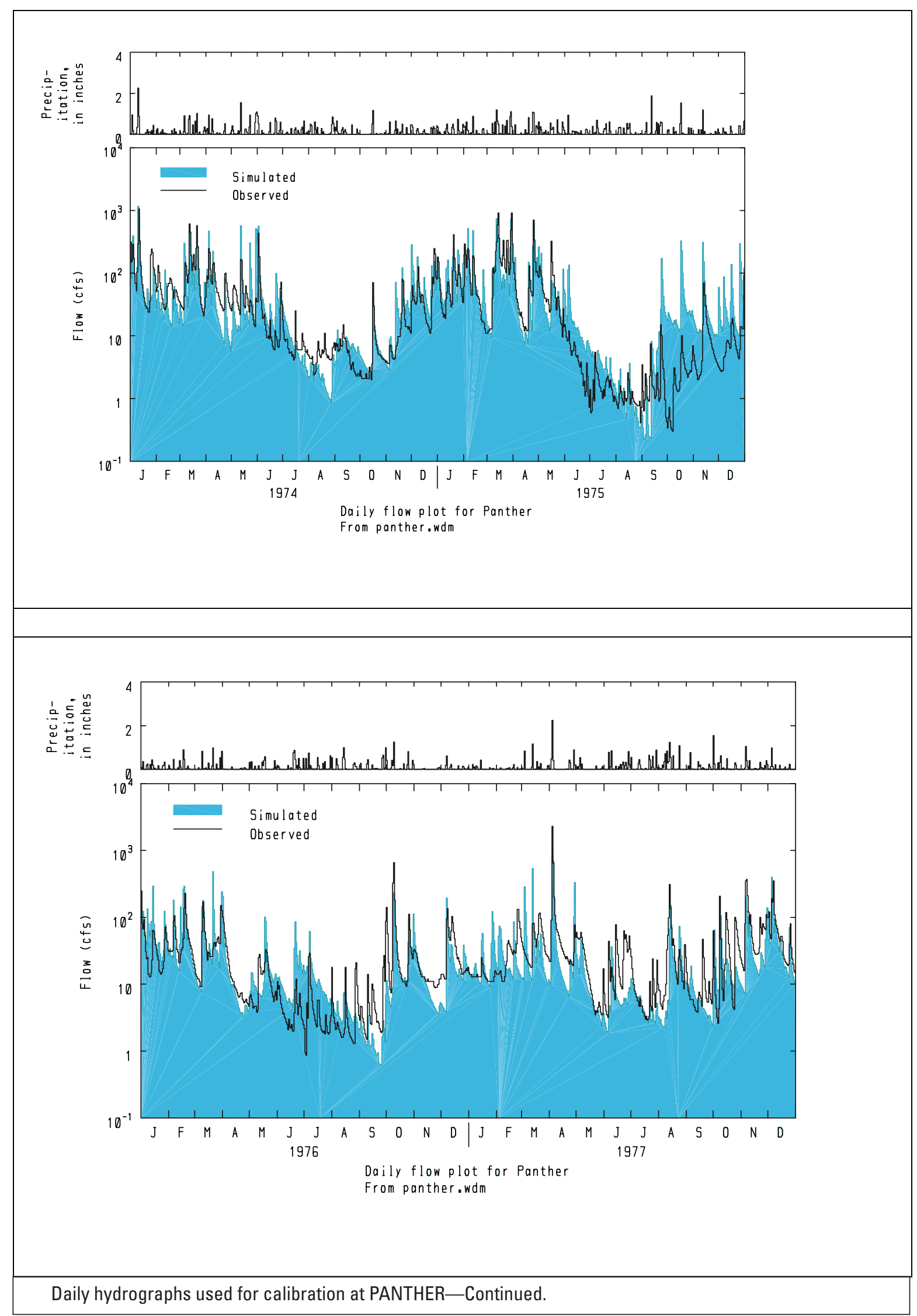




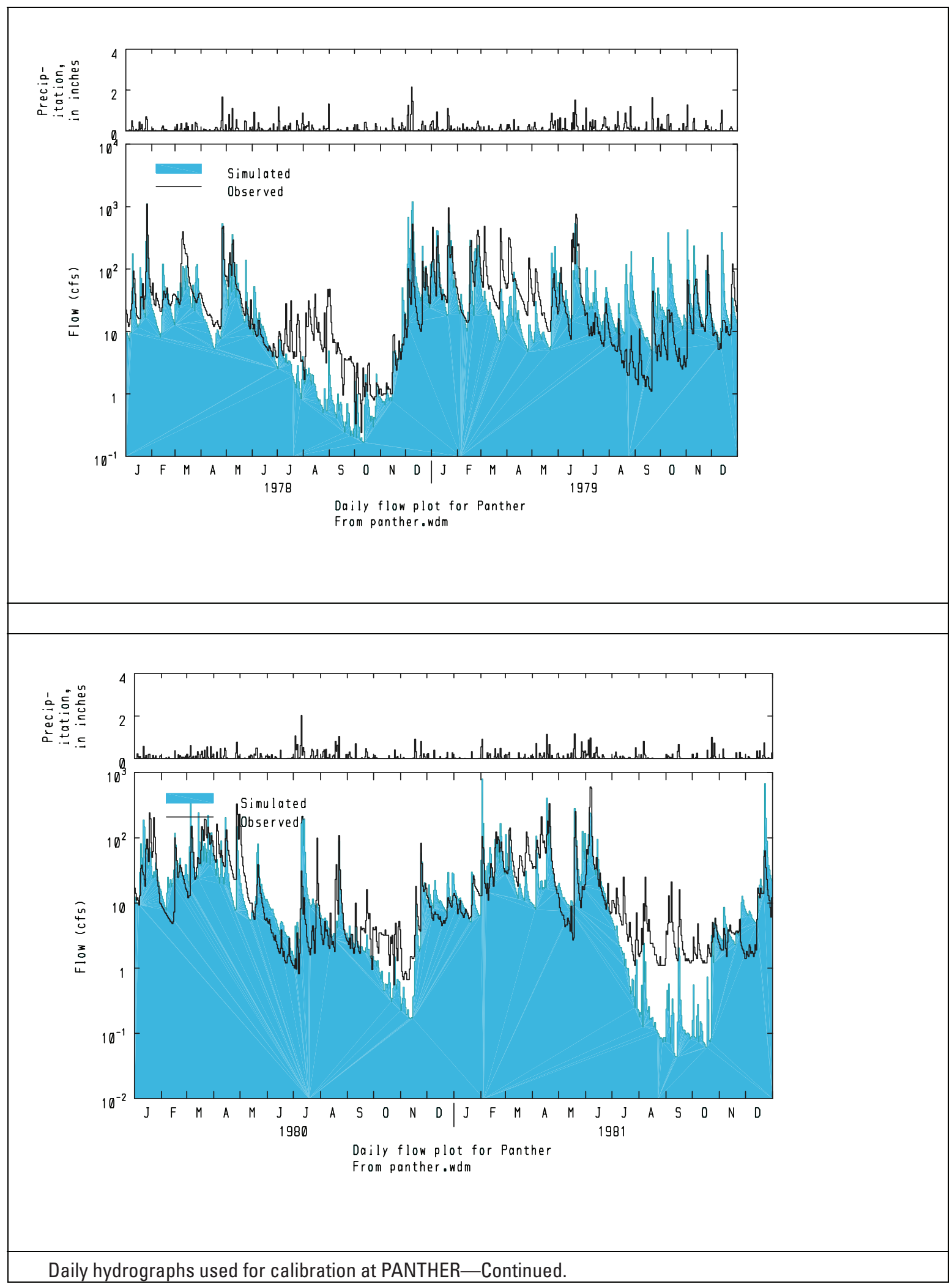




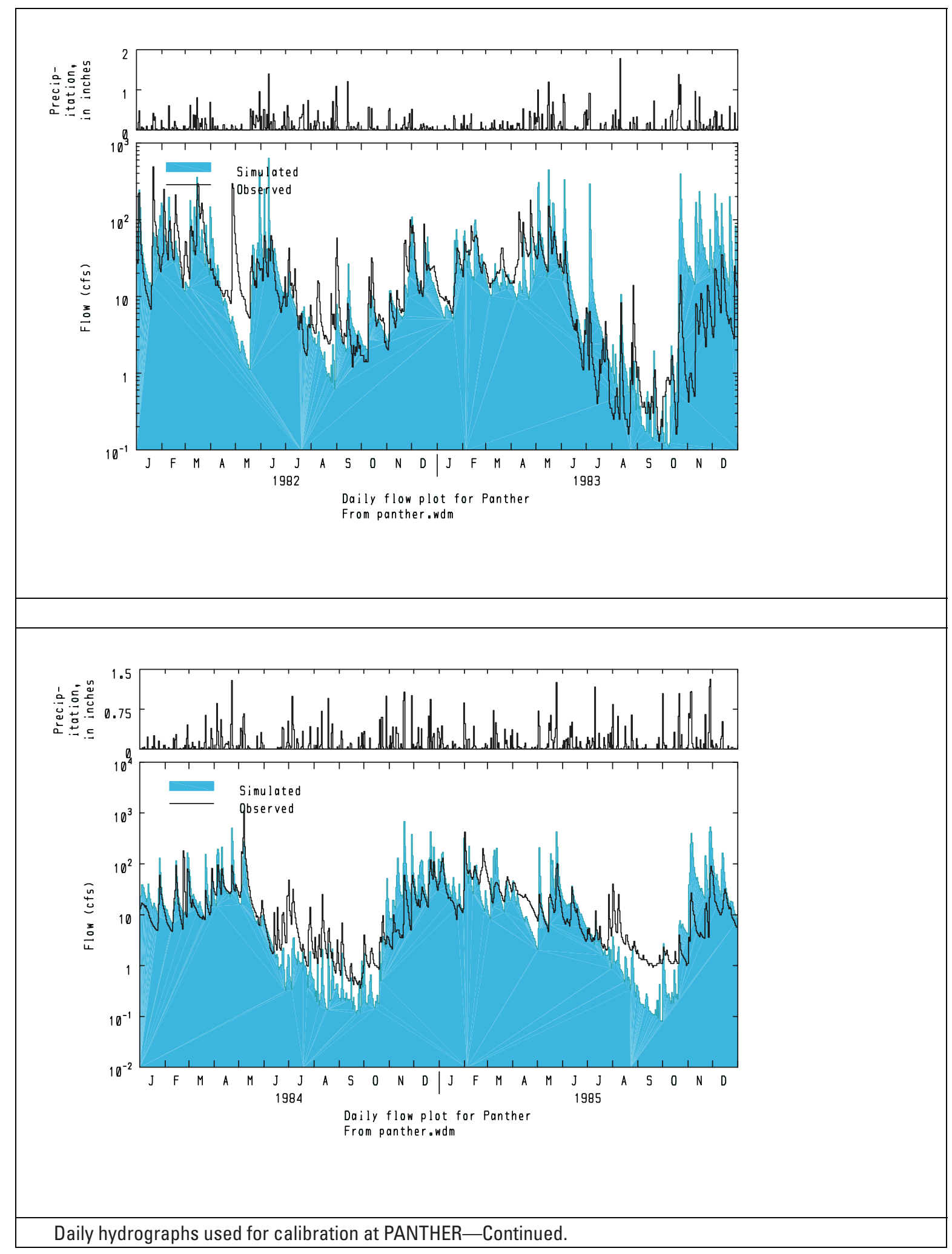




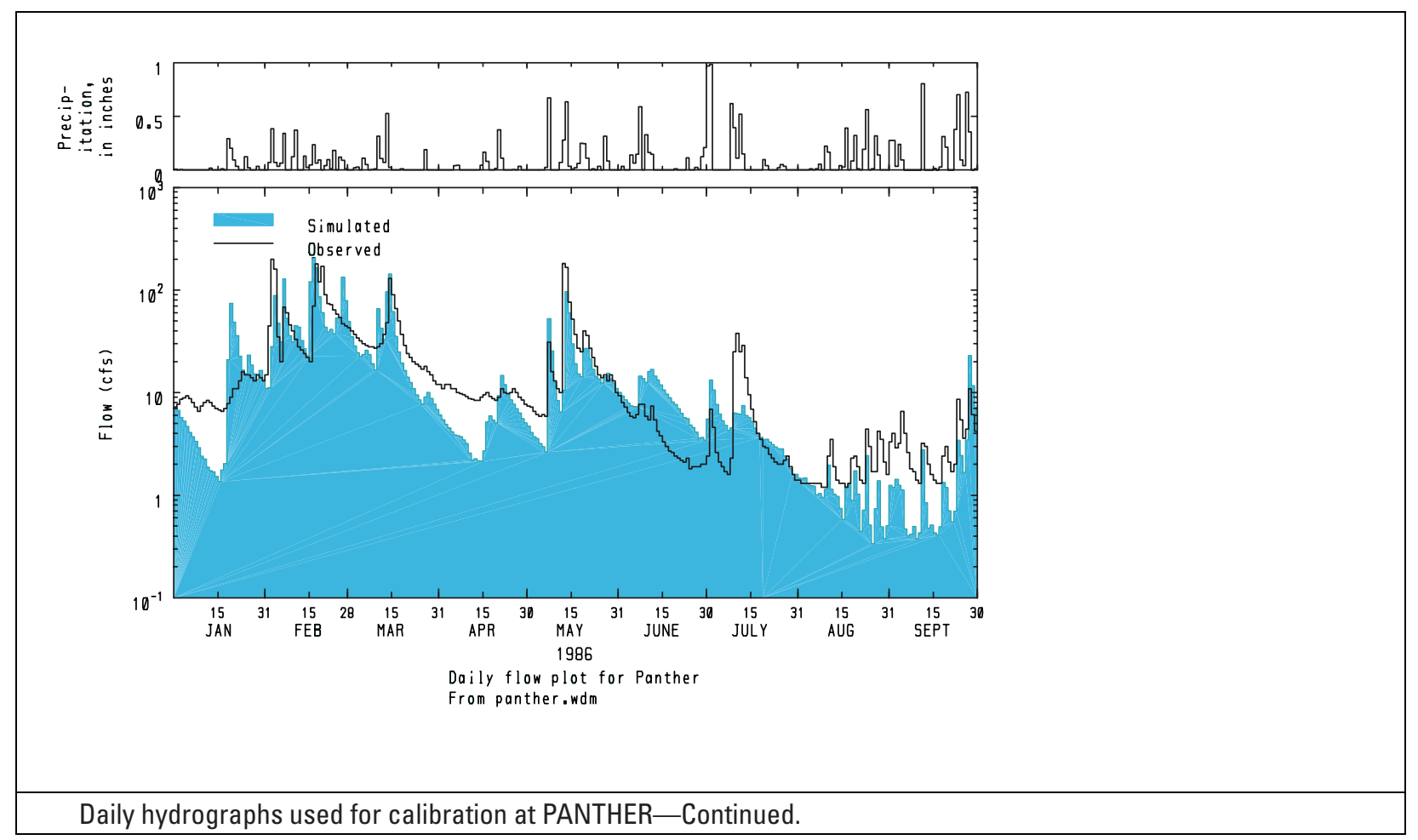




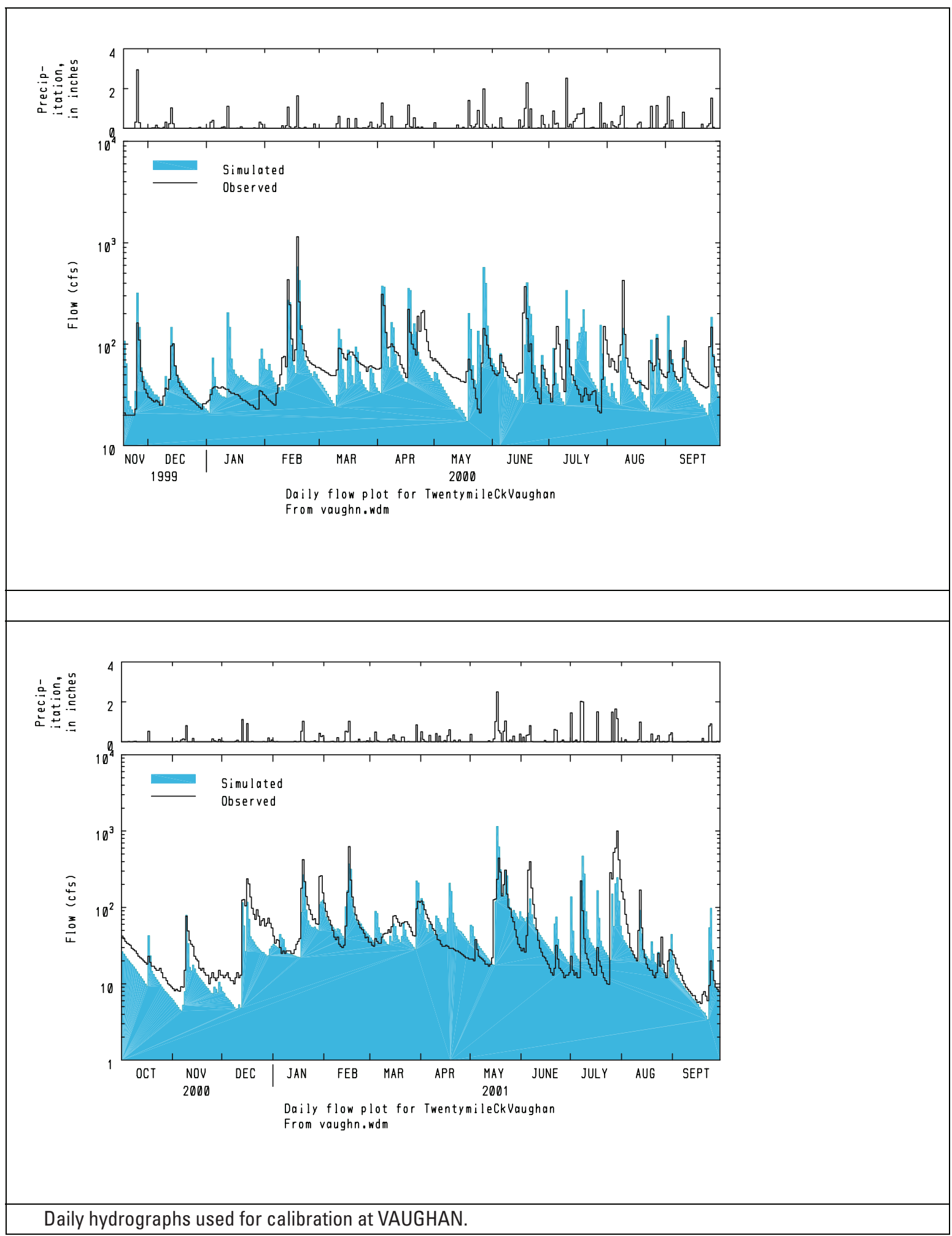




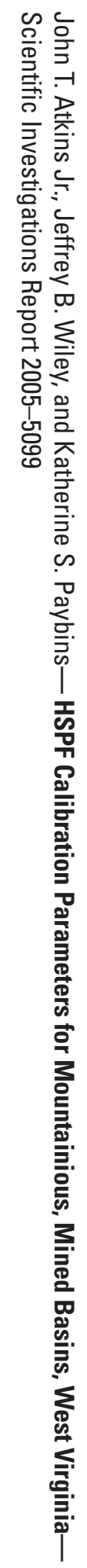

